\title{
Environmental Studies of Mineral \\ Deposits in Alaska
}

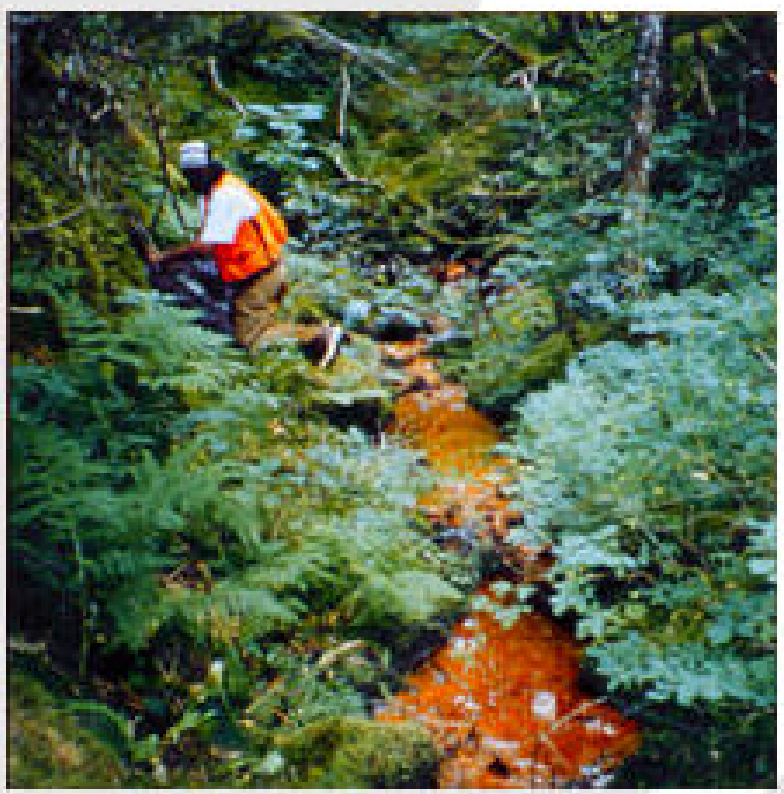

U.S. GEOLOGICAL SURVEY BULLETIN 2156 


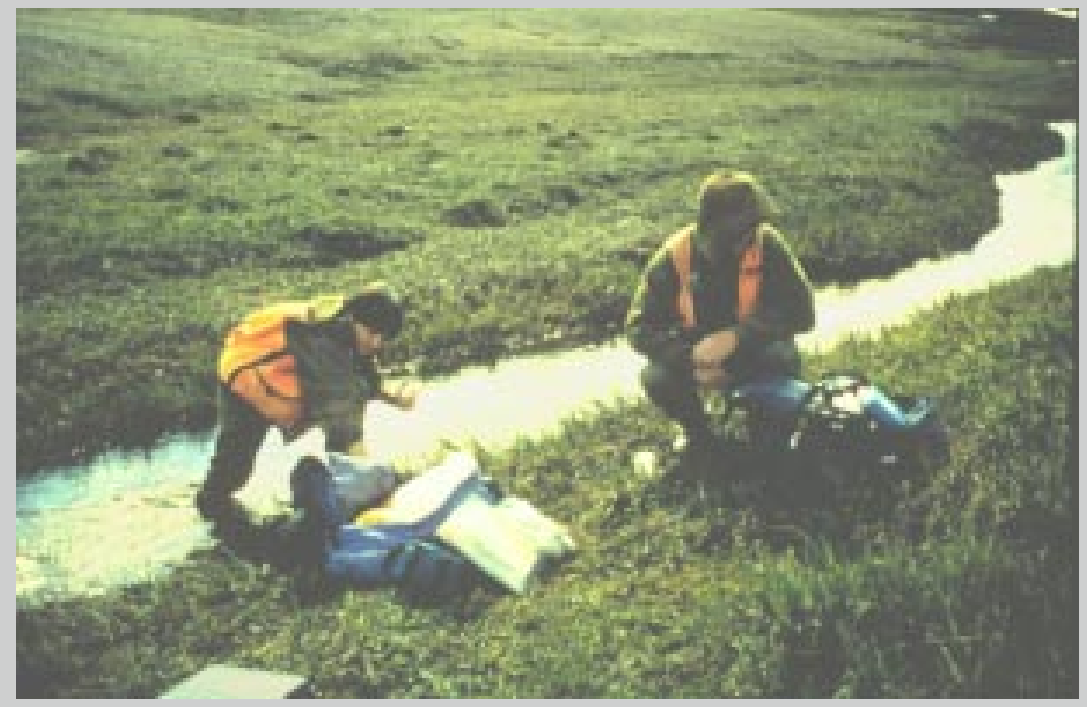

Right. A sample of the ore mineral cinnabar (red mineral) collected from one of several abandoned mercury mines in southwestern Alaska. The mines in the region were studied to evaluate effects of mercury on surrounding ecosystems.

Above. Geologists from the U.S. Geological Survey collecting water samples downstream from a massive sulfide deposit, northwestern Brooks Range, Alaska. Stream characteristics such as trace-element concentrations in stream sediments and stream waters, and streamwater $\mathrm{pH}$ and conductivity were measured downstream from several mineral deposits in Alaska to evaluate effects of these deposits on surrounding environments.

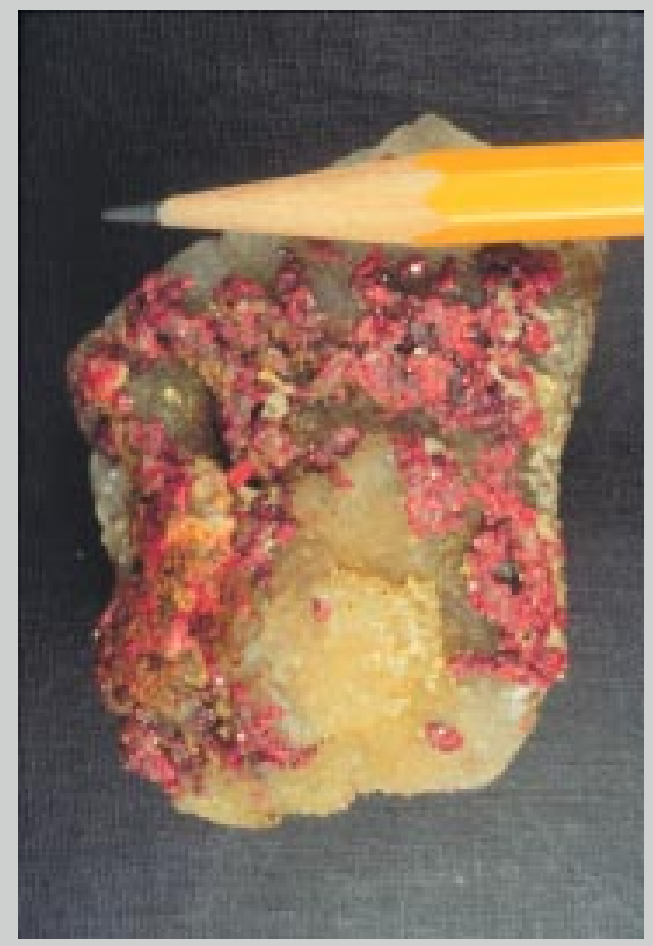

Front Cover. Acid-mine drainage found below the Duke mine, a massive sulfide deposit in the Prince William Sound area, Alaska (lower left); collecting water samples downstream from the Drenchwater massive sulfide deposit in the northwestern Brooks Range, Alaska (upper right). 


\section{Environmental Studies of Mineral Deposits in Alaska}

\section{U.S. GEOLOGICAL SURVEY BULLETIN 2156}

Short articles summarize environmental geochemical studies of metallic mineral deposits in Alaska, including massive sulfide, gold, mercury, chromium, and uranium mines and deposits. The studies report metal and acid concentrations in samples collected around such mines and deposits, and evaluate environmental effects of the deposits. The articles are written in a style intended to reach a general audience

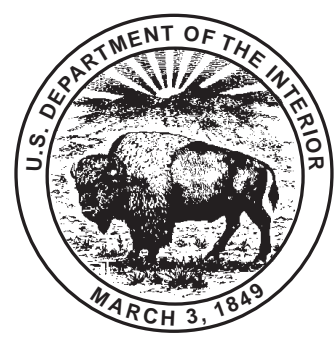

Edited by John E. Gray and Richard F. Sanzolone

With contributions from

Elizabeth A. Bailey Karen D. Kelley Helen W. Folger Keith A. Mueller*

Richard J. Goldfarb Steven W. Nelson

Larry P. Gough James K. Otton

John E. Gray

John A. Philpotts
Richard F. Sanzolone

Elaine Snyder-Conn*

Clifford D. Taylor

Peter M. Theodorakos

*U.S. Fish and Wildlife Service 


\title{
U.S. DEPARTMENT OF THE INTERIOR BRUCE BABBITT, Secretary
}

\author{
U.S. GEOLOGICAL SURVEY \\ Gordon P. Eaton, Director
}

For sale by U.S. Geological Survey, Information Services

Box 25286, Federal Center

Denver, CO 80225

\author{
Any use of trade, product, or firm names in this publication is for descriptive purposes only and \\ does not imply endorsement by the U.S. Government \\ Library of Congress Cataloging-in-Publication Data \\ Environmental studies of mineral deposits in Alaska / edited by John E. Gray and Richard \\ F. Sanzolone ; with contributions from Elizabeth A. Bailey . . . . [et al.]. \\ p. cm.-(U.S. Geological Survey bulletin ; 2156) \\ Includes bibliographical references (p. ). \\ 1. Metals-Environmental aspects-Alaska. 2. Mines and mineral resources- \\ Environmental aspects-Alaska. I. Gray, John E., 1956-. II. Sanzolone, R.F. \\ III. Bailey, Elizabeth A. IV. Series. \\ TD196.M4E58 1997 \\ [QE75.B9] \\ $551.9^{\prime} 09798-\mathrm{dc} 20$ \\ 96-13189




\section{CONTENTS}

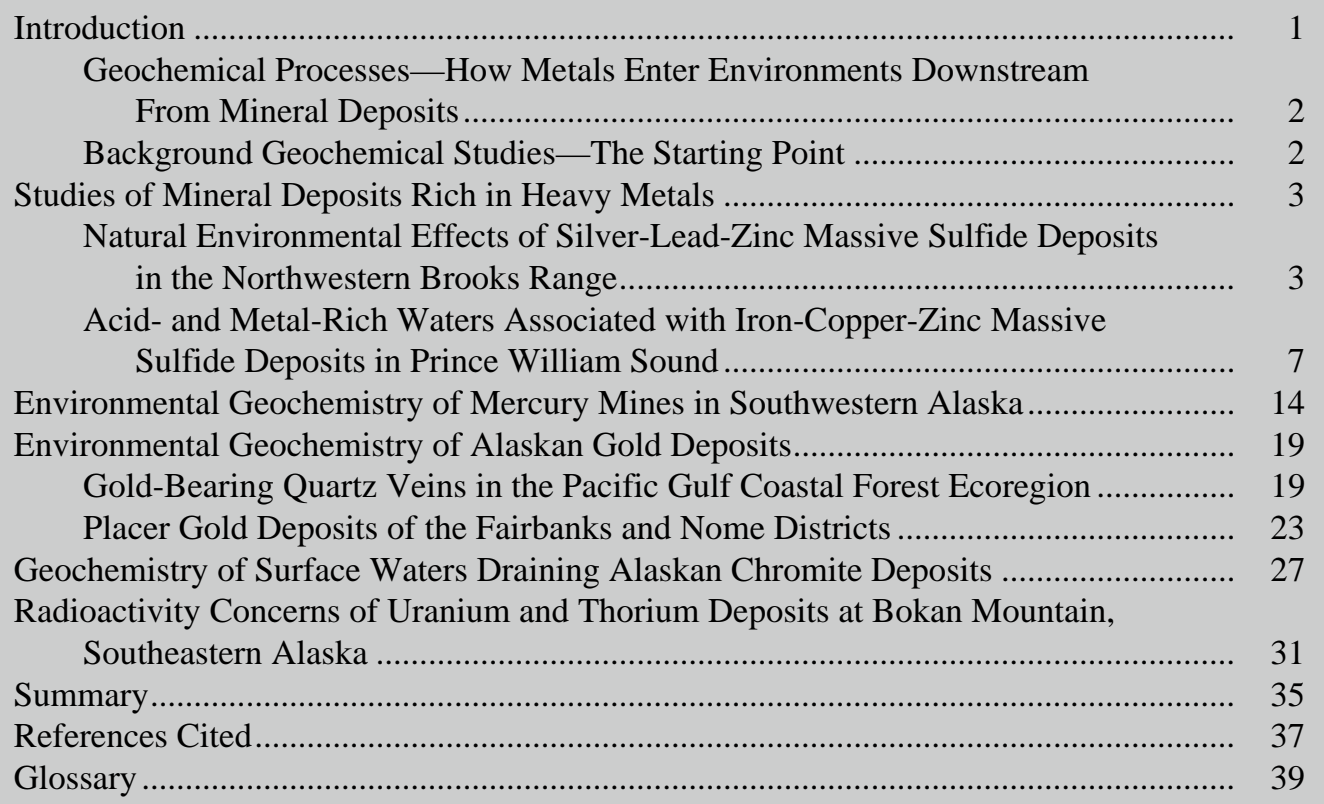

\section{FIGURES}

1. Map showing location of silver-lead-zinc deposits in the northwestern Brooks Range, Alaska ..

2. Photographs in the northwestern Brooks Range, of Red Dog Creek mineral deposit prior to mining, and of intense red-weathering zones near Drenchwater Creek

3. Plots demonstrating how water from Discovery Creek affects dissolved zinc in lower Drenchwater Creek.

4. Photograph of a bright-orange iron-oxide layer along False Wager Creek, which drains Drenchwater deposit on east side

5. Photograph of mineralized rock from a volcanic-rock-hosted massive sulfide deposit showing veins with abundant chalcopyrite and pyrrhotite, Prince William Sound ...

6. Photograph of abandoned tailings piles (background) near the Dutchess mine

7. Map showing location of massive sulfide deposits studied, Prince William Sound

8. Photograph of water effluent discharging from base of tailings piles at the Dutchess mine

9. Photograph of tailings and effluent from the Beatson mine washing into Prince William Sound, and view of flooded Beatson pit.

10. Map showing location of mercury mines and deposits in southwestern Alaska... 2 3 7 9 1

(1)


17. Photograph of open-pit cut, Alaska-Juneau mine, near Juneau, Alaska

18. Photograph showing geologists sampling waters draining an adit from an abandoned gold mine in southern Alaska.

19. Map showing location of gold placers in Alaska...

20. Photograph showing placer operation near Fairbanks .....

21. Photograph of Red Mountain chromium deposit, showing color and vegetation contrast between ultramafic rock and vegetated soil

22. Photograph showing a seam of black chromite ore layered within the ultramafic rocks at Red Mountain..................

23. Location map of the Alaskan chromium occurrences studied

24. Photograph showing water flowing from an abandoned chrome mine.

25. Map showing location of Bokan Mountain uranium deposits, southeastern Alaska

26. Photograph of the granitic intrusion at Bokan Mountain.....

27. Photograph showing previous mining of uranium ore at the Ross-Adams uranium mine .....

28. Plot of dissolved metal concentrations in water versus water $\mathrm{pH}$ for several Alaskan deposit types 36

\section{TABLES}

1. Water standards used for reference in these studies

2. Geochemical data summary of mineral deposits studied. 


\title{
Environmental Studies of Mineral Deposits in Alaska
}

\author{
Edited by John E. Gray and Richard F. Sanzolone
}

\section{INTRODUCTION}

Mining of minerals and metals is important in all industrialized and developing countries. In the United States, mining of metallic mineral deposits is conducted in most States, including Alaska. In the past century, much of the mining has concentrated on the extraction of metals necessary for the economic or industrial development of societies, for example, gold, silver, iron, copper, lead, zinc, chromium, mercury, tin, cobalt, molybdenum, nickel, and uranium. Other metals such as arsenic, cadmium, and selenium are often enriched in mineral deposits and recovered as byproducts. Because many of these metals can be toxic to plants, animals, and humans, their interaction with the environment is a national concern. To address this concern, studies of natural and man-made environmental interactions of metals before, during, and after mining have become increasingly important to society.

The economic success of any mineral deposit depends on a clear understanding of its geology, mineralogy, and geochemistry, because these characteristics aid in locating, developing, and extracting metals and minerals from ore deposits. These characteristics also affect surrounding environments, because metals can be carried downstream from the deposits and into local ecosystems. ${ }^{1}$ With a thorough understanding of the characteristics of mineral deposits and their downstream effects, scientists can predict potential environmental problems and identify solutions to these problems.

To evaluate environmental concerns, scientists measure metal concentrations in rock, soil, stream-sediment, water, plant, and sometimes fish samples collected around mines and mineral deposits. Metal concentrations in these samples are typically compared to Federal and State standards, as well as to local background concentrations. These measurements are the initial steps toward identifying environmental contamination problems associated with mineral deposits, both prior to, and resulting from mining.

\footnotetext{
${ }^{1}$ Italicized terms are defined in the Glossary; see page 39.
}

The most important environmental concerns resulting from weathering and mining of mineral deposits are increased acid and metal concentrations downstream that can potentially degrade drinking water and wildlife habitat. Thus, the primary objectives of the studies presented here are to:

- determine metal and acid concentrations in samples collected downstream from mineral deposits,

- assess the degree of metal contamination in local streams due to weathering and mining of the deposits, and

- evaluate environmental effects related to the mineral deposits.

Such studies are particularly important in Alaska: a number of known mineral deposits exist that have not yet been developed, and these studies may be useful for future mining, monitoring, and remediation programs within the State. These studies may also be useful for evaluation, development, and remediation of mineral deposits of similar type in similar geographic and geologic settings.

The U.S. Geological Survey (USGS) is working with several agencies in Alaska, including the U.S. Fish and Wildlife Service, U.S. Forest Service, National Park Service, and Alaska native corporations, to evaluate the environmental effects of mineral deposits and their mining. In cooperation with these agencies, the USGS has the unique ability to integrate aspects of geology, mineralogy, and downstream geochemistry of mineral deposits in Alaska and identify any environmental hazards related to these deposits. Studies of the geology, mineralogy, and geochemistry of mineral deposits can be integrated with local climatic, hydrologic, and topographic conditions to address land use and environmental issues. This publication summarizes the results from some of the first environmental studies of mineral deposits in Alaska conducted by the USGS. Some of the text is technical, and a glossary of some technical terms is provided. These technical terms are in italics when first mentioned throughout the text. 


\section{GEOCHEMICAL PROCESSES-HOW MET- ALS ENTER ENVIRONMENTS DOWNSTREAM FROM MINERAL DEPOSITS}

Rocks and minerals exposed at or near the surface of the Earth undergo changes in color, form, and chemical composition. This process, called weathering, is primarily the result of the action of air, wind, water, snow, ice, and biological activity on the rocks and minerals in mined and unmined mineral deposits. Weathering can result in the formation of acid water and conversion of metals into water soluble forms. These acid- and metal-rich waters are commonly referred to as acid drainage. Formation of acid drainage around mineral deposits is primarily related to oxidation of sulfide minerals, especially pyrite (iron sulfide), that produces strong acids like sulfuric acid. Many heavy metals, including arsenic, copper, lead, zinc, and cadmium, contained within sulfide minerals in the mineral deposits, are more soluble in water containing abundant acid. When these acid- and metal-rich waters flow downstream from a mineral deposit, they may be an environmental concern, if they adversely affect local wildlife habitat or human health.

At the same time that rocks and minerals are weathering, they are also being eroded, transported, and redeposited downstream. During this erosion process, the physical and chemical changes of the rocks and minerals continue at the site of the mineral deposit, which is the primary source of the metals, as well as in streams below the deposits. Therefore, acid- and metal-rich waters will continue to form until these metal sources are removed by natural or human processes.

\section{BACKGROUND GEOCHEMICAL STUDIES-THE STARTING POINT}

To determine if metal concentrations around mineral deposits are of environmental concern, scientists collect a series of samples, chemically analyze these samples for metal concentrations, and then determine which metal concentrations are "normal or usual" and which are "high or unusual." Materials sampled for study are usually stream water, stream sediment, soil, and sometimes fish and plants. The initial step in mineral deposit environmental studies is to collect samples upstream from such mineral deposits, or from areas where mineral deposits are not known. Samples collected from such unmineralized areas are referred to as "background" samples. When these background samples are chemically analyzed, they provide the chemical concentrations that are considered normal or usual and are unaffected by mineral deposits or mining. These background samples provide scientists with a reference or starting point against which to compare chemical data from samples collected downstream from mined and unmined mineral deposits. In many instances, samples collected downstream from mineral deposits contain high metal concentrations that greatly exceed those in background samples. These high concentrations must be closely evaluated to determine if the environment has been adversely affected. In the following studies, data are presented to examine metal concentrations and related hazards around several types of mineral deposits. 


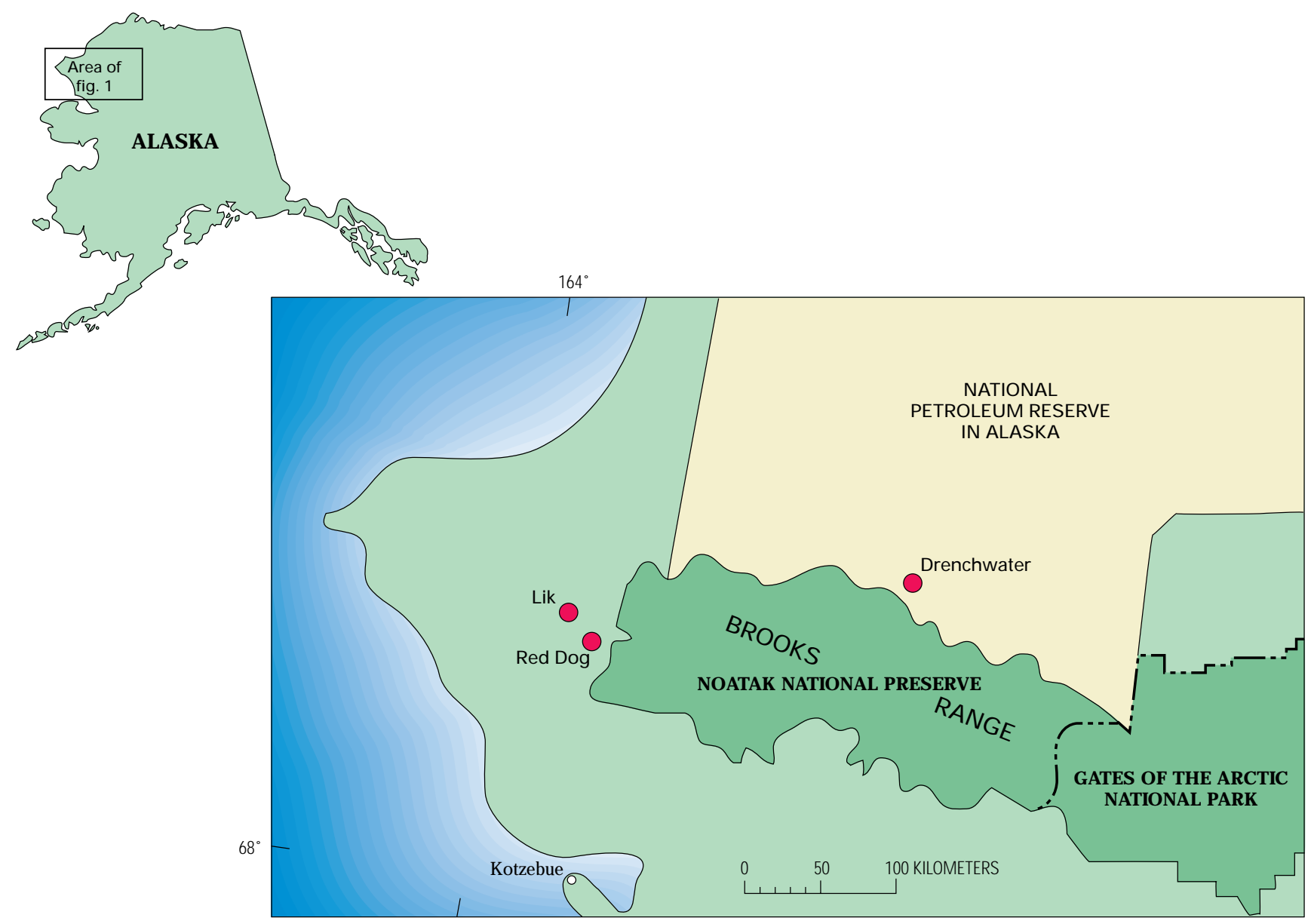

Figure 1. Location of silver-lead-zinc massive sulfide deposits in the northwestern Brooks Range, Alaska.

\section{STUDIES OF MINERAL DEPOSITS RICH IN HEAVY METALS}

Mineral deposits containing large amounts of sulfide minerals are of environmental concern because heavy metals such as copper, lead, zinc, and cadmium are highly concentrated in these deposits. Mineral deposits containing such large amounts of sulfide minerals are commonly referred to as massive sulfide deposits. The State of Alaska contains several types of massive sulfide deposits. The massive sulfide deposits studied here are (1) those found primarily in sedimentary rocks in the northwestern Brooks Range and (2) those closely associated with volcanic rocks or lavas in Prince William Sound.

\section{NATURAL ENVIRONMENTAL EFFECTS OF SILVER-LEAD-ZINC MASSIVE SULFIDE DEPOSITS IN THE NORTHWESTERN BROOKS RANGE}

Silver-lead-zinc massive sulfide deposits in the northwestern Brooks Range consist of layers rich in sulfide minerals that are dispersed in black shale and chert. The dominant minerals are sphalerite (zinc sulfide), silver-rich galena (lead sulfide), pyrite, and marcasite (iron sulfides). The deposits currently under study in the Brooks Range are Lik, Drenchwater, and Red Dog (Kelley, 1995) (fig. 1). At Red Dog, one of the largest zinc deposits in the world, mining of lead and zinc began in 1990 and continues today. The Lik and Drenchwater deposits have not been mined. All three deposits are exposed at the surface and were discovered by the presence of orange staining on surrounding hillsides or by the presence of significant heavy metal concentrations in streams draining the deposits (fig. 2). 
Figure 2A. Photograph in the northwestern Brooks Range of Red Dog Creek prior to mining where it flowed through the mineral deposit. Red Dog Creek had significant natural heavy-metal contamination that eliminated fish life in the vicinity of the deposit. The contamination and resulting mineral stain led to discovery of the Red Dog deposit (photo by C.G. Mull).

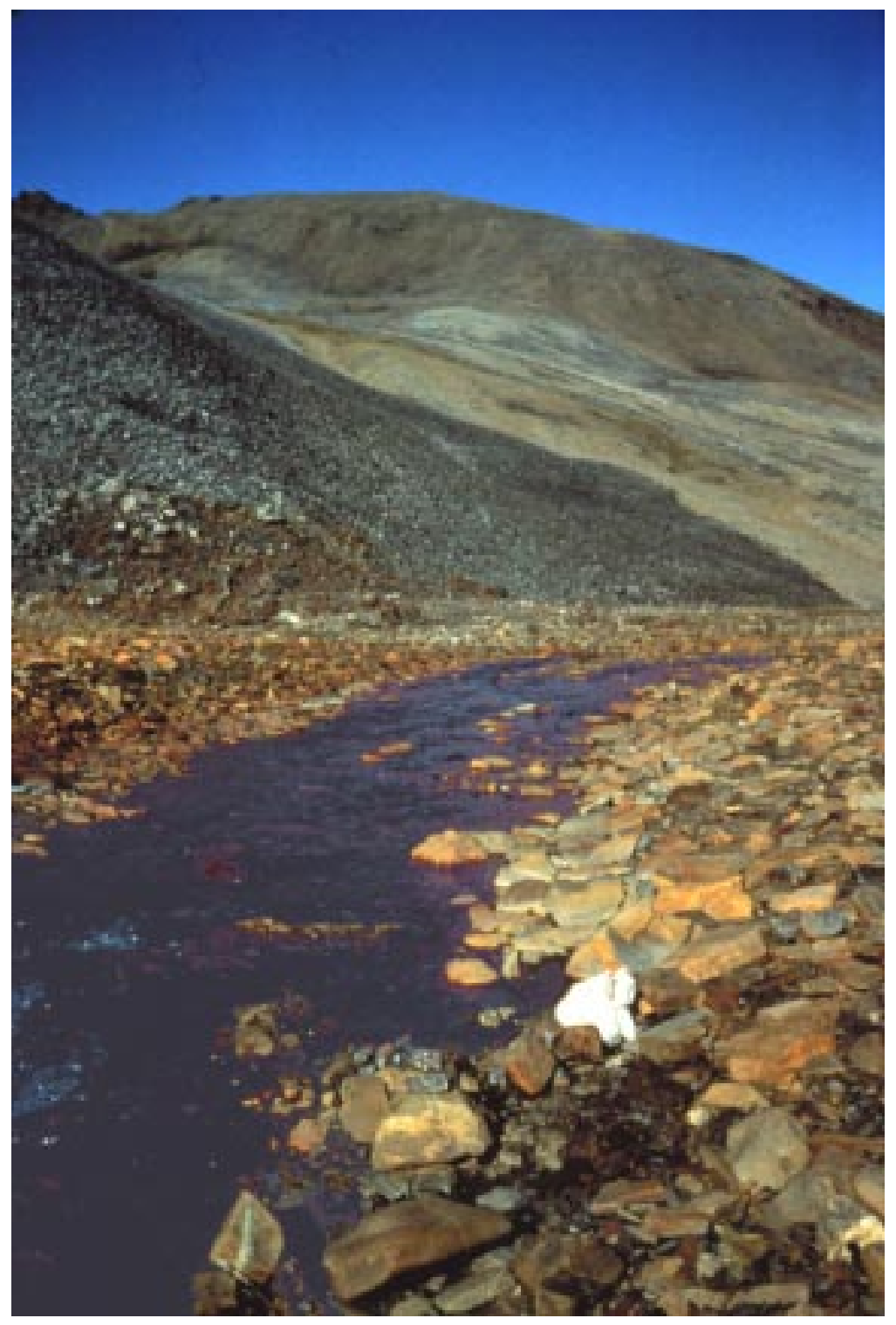

What are the environmental issues of the Brooks Range massive sulfide deposits?-The Brooks Range massive sulfide deposits have the potential to form acidand metal-rich waters that can carry high concentrations of toxic metals such as lead, zinc, and cadmium. Several thousand people living in the surrounding region traditionally rely on subsistence hunting and fishing for food sources. These silver-lead-zinc massive sulfide deposits can be a potential hazard to residents and wildlife, if drainage from these deposits enters streams and rivers that support local wildlife habitat. To evaluate stream water quality near the deposits, scientists measured concentrations of metals and $\mathrm{pH}$ in water collected from streams surrounding these silver-lead-zinc deposits. 


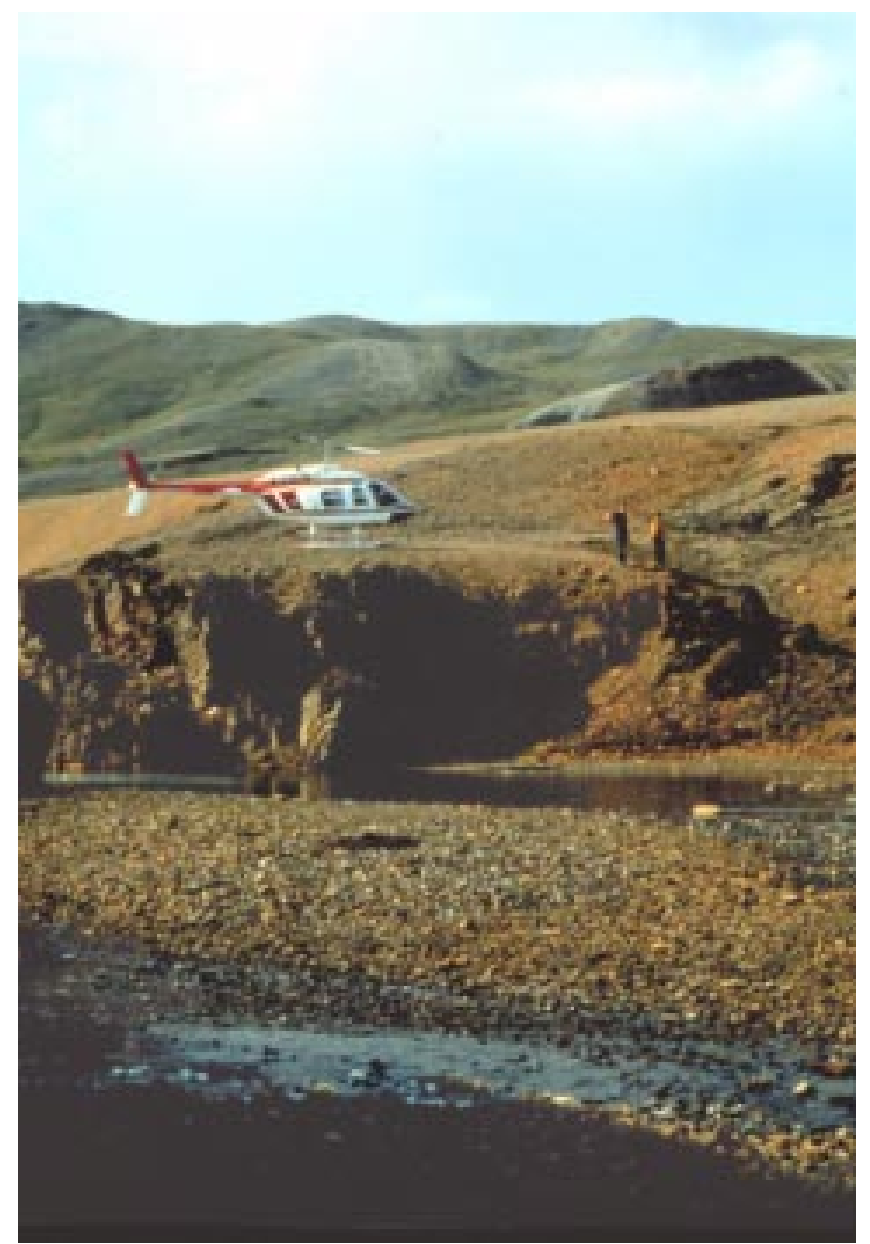

Figure 2B. Photograph in the northwestern Brooks Range looking west across Drenchwater Creek. The weathering of pyrite has resulted in intense red-weathering zones.

Water quality downstream from massive sulfide deposits is significantly affected.-Data from the Drenchwater deposit indicate that stream waters draining the deposit have low $\mathrm{pH}$ values (indicating that they are acidic), and dissolved concentrations of aluminum, arsenic, cadmium, copper, iron, lead, manganese, nickel, and zinc are several orders of magnitude greater than that in water samples collected upstream (backgrounds) from the deposit (fig. 3 ). The most acidic waters collected range in $\mathrm{pH}$ from 2.8 to 3.1 and contain as much as 95,000 ppb (parts per billion) aluminum, $26 \mathrm{ppb}$ arsenic, 270,000 ppb iron, 8 ppb cadmium, 260 ppb copper, 10 ppb lead, 3,400 ppb manganese, $290 \mathrm{ppb}$ nickel, and 2,600 ppb zinc; these values are all significantly above background concentrations (Kelley and Taylor, 1996). Sulfate concentrations (1,180 ppm (parts per million)) are also high. Although the deposits are rich in silver, water samples contain low silver concentrations $(<0.1$ $\mathrm{ppb})$. Locally, the iron- and sulfate-rich waters have precipitated a bright-orange iron-oxide layer that cements the stream pebbles and cobbles on the creek bottom (fig. 4).
Table 1. Water standards used for reference in these studies.

[Concentrations are in ppb (micrograms per liter); --, standard has not been established]

\begin{tabular}{|c|c|c|}
\hline Element & $\begin{array}{l}\text { EPA criteria } \\
\text { maximum } \\
\text { concentration } \\
(\mathrm{CMC})^{1}\end{array}$ & $\begin{array}{l}\text { State of Alaska } \\
\text { maximum } \\
\text { contaminant } \\
\text { level (MCL) }\end{array}$ \\
\hline
\end{tabular}

\begin{tabular}{lcr}
\hline Arsenic & 360 & 50 \\
Antimony & -- & 6 \\
Mercury & 32.4 & 2 \\
& & \\
Copper & 18 & 1,000 \\
Lead $^{4}$ & 82 & -- \\
Zinc $^{4}$ & 120 & 5,000
\end{tabular}

\begin{tabular}{|c|c|c|}
\hline Cadmium 4 & 3.9 & 5 \\
\hline Iron & -- & 300 \\
\hline Sulfate & -- & 250,000 \\
\hline m & 1,700 & $5_{100}$ \\
\hline Chromium V & 16 & -- \\
\hline
\end{tabular}

${ }^{1} \mathrm{CMC}$ is the Environmental Protection Agency's water quality criteria to protect against acute effects in aquatic life and is the highest instream concentration of a toxic pollutant consisting of a 1-hour average not to be exceeded more than once every 3 years on the average.

${ }^{2} \mathrm{MCL}$ is the maximum concentration allowed by the State of Alaska in public drinking water systems. Concentrations listed for copper, zinc, iron, and sulfate are secondary MCL's that are reasonable totals and provide a general guideline for public drinking water systems.

${ }^{3}$ The CMC for mercury in seawater is $2.1 \mathrm{ppb}$.

${ }^{4}$ These element standards vary with water hardness. Values listed are for a water hardness of 100 , which is similar to that for streams studied here.

${ }^{5}$ Standard is for total chromium concentration.

Although metal concentrations in waters draining the Drenchwater deposit are higher than streams in unmineralized areas, many metals are still present at levels below the State of Alaska drinking water standards. Levels of cadmium, copper, and zinc exceed the instream criteria maximum concentrations (CMC) that the U.S. Environmental Protection Agency (EPA) indicates may acutely affect aquatic life (table 1). 


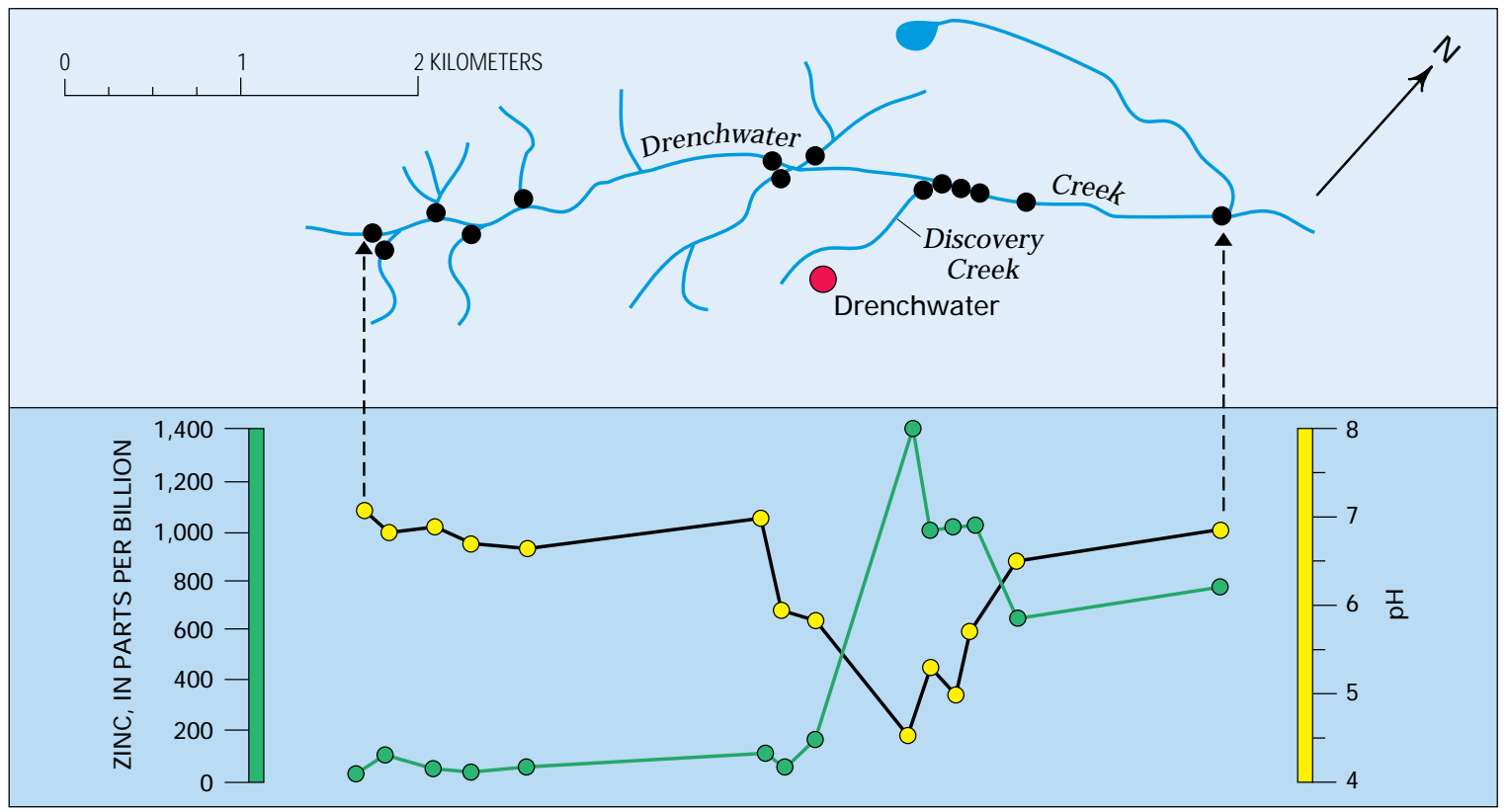

Figure 3. Plots demonstrating how the stream water from Discovery Creek, which drains mineralized areas, affects the dissolved zinc in lower Drenchwater Creek. Aluminum, cadmium, copper, iron, lead, manganese, and nickel show variations in concentrations similar to zinc that reflect the input of water contaminated by metals naturally weathering from the mineralized area. In addition, the $\mathrm{pH}$ of water downstream from the deposit dramatically decreases (acidity increases). Data were collected in July 1994.

The Red Dog massive sulfide deposit contributes high acid and metal contents to stream waters, similar to the Drenchwater deposit. The only significant difference between the two is the higher metal concentrations in Red Dog waters relative to Drenchwater. Water quality data from streams draining the Red Dog deposit prior to mining (Dames and Moore, 1983; Runnels and others, 1992) reveal that the waters were acidic (as low as a pH of 3.5) and contained toxic levels of cadmium (as much as $800 \mathrm{ppb}$ ), lead $(2,250 \mathrm{ppb})$, and zinc $(272,000 \mathrm{ppb})$. These concentrations exceeded the drinking water standards recommended by the State of Alaska (5 ppb Cd; $15 \mathrm{ppb} \mathrm{Pb}$; and 5,000 ppb Zn) and the EPA-CMC standards (table 1). Other metals, such as aluminum, chromium, copper, iron, manganese, mercury, nickel, and silver, slightly exceeded EPA-CMC standard. Streams immediately draining the Red Dog deposit did not support any significant biota, such as fish, suggesting that waters were apparently toxic to most aquatic life prior to mining. Stream water quality $15-20 \mathrm{~km}$ downstream of the deposit was also significantly affected: zinc and cadmium concentrations were well above the recommended CMC concentrations.

The higher metal concentrations of Red Dog waters relative to Drenchwater are due primarily to the greater amount of sulfide minerals present in the Red Dog deposit and the greater extent of exposure of sulfide minerals to weathering at the surface.
When geology differs, so does the water quality.-The Lik deposit yields waters that are near-neutral to neutral, and concentrations of all metals except zinc are low relative to Drenchwater and Red Dog. Stream waters collected downstream from Lik have $\mathrm{pH}$ values of 6.2 to 8.1. Only one sample from a small tributary contained concentrations of cadmium (5 ppb) and zinc (2,000 ppb) that are comparable to levels detected below the Drenchwater deposit. Zinc was the only metal that was consistently high in water samples below the deposit, ranging from 380 to 2,000 ppb.

Differences in chemistry between the Drenchwater and Lik deposits may be attributed to the presence of carbonate rocks, such as limestone, surrounding the Lik deposit. Carbonate rocks tend to neutralize acid in the water and, because metals are more soluble in water containing significant acid, these near-neutral waters have a lesser ability to transport most metals in solution. 


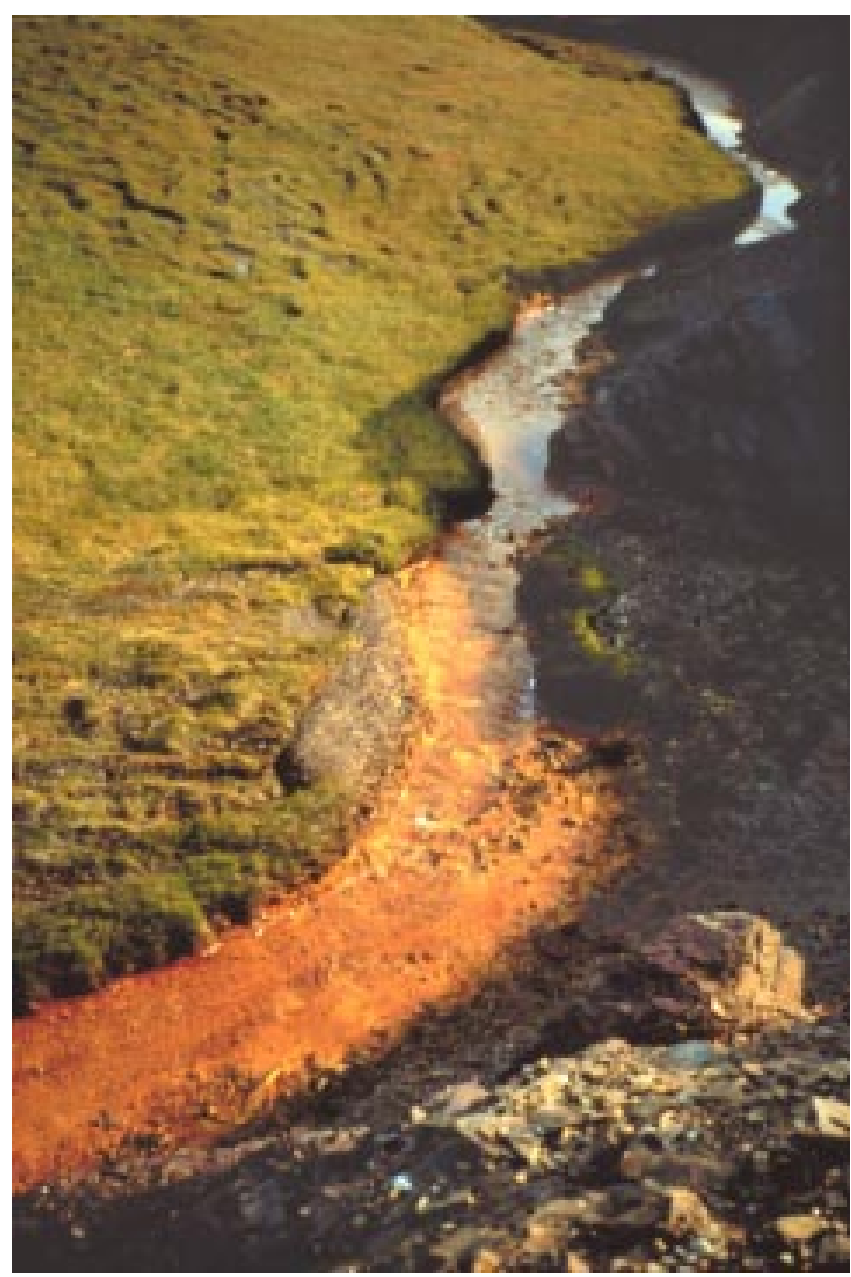

Figure 4. A bright-orange iron-oxide layer locally covers the bottom and cements stream pebbles and cobbles along False Wager Creek, which drains the Drenchwater deposit on the east side. The orange part of the stream in this photo is about $1.5-2 \mathrm{~m}$ wide.

What has the Brooks Range massive sulfide data told us?-These results show that the primary factors affecting water chemistry are the extent of exposure of the deposits, the amount of sulfide minerals present, and the presence or absence of carbonate rocks. In the absence of carbonate rocks, silver-lead-zinc massive sulfide deposits in the Brooks Range can produce significant naturally occurring heavy-metal concentrations in downstream waters. Carbonate rocks are not present at the Red Dog and Drenchwater deposits, and waters are highly acidic and metal rich. In contrast, carbonate rocks are abundant at the Lik deposit, and waters are near-neutral and contain low concentrations of most metals except zinc.

These data are useful for predicting the environmental effects likely to result from natural weathering of massive sulfide deposits and from possible future mining of such deposits. Furthermore, the data enable mine planners to better anticipate, plan for, and mitigate potential environmental problems, and are useful for devising realistic plans for remediation and monitoring programs.

\section{ACID- AND METAL-RICH WATERS ASSOCIATED WITH IRON-COPPER-ZINC MASSIVE SULFIDE DEPOSITS IN PRINCE WILLIAM SOUND}

Massive sulfide deposits in Prince William Sound consist of iron-, copper-, and zinc-rich sulfide minerals in and near volcanic rocks. Many of the deposits were mined from about 1900 to 1930, but have since been abandoned. These abandoned mines are located in the Chugach National Forest and on private lands within the forest.

Rocks in the Prince William Sound region are dominantly sandstone and slate, with some basalt. The massive sulfide deposits are most common in basalt, but are found also in nearby sedimentary rocks. The primary sulfide minerals are pyrite, pyrrhotite, chalcopyrite, and sphalerite (fig. 5). Minor galena is present in some deposits. Sulfide-rich bodies range in size from a few centimeters to 90 $\mathrm{m}$ wide and a few hundred meters long.

Workings range from small prospect trenches to mines with tunnels hundreds of meters long. The Beatson mine contains more than $4 \mathrm{~km}$ of tunnels and a $300 \mathrm{~m}$ diameter open pit. Small tailings piles, about 10 to $20 \mathrm{~m}$ high, are found at most mine sites (fig. 6 ). These tailings generally are bright red as a result of the weathering of sulfide minerals. Bright-green to black moss covers metal-rich soils where the landscape was stripped for mining. Mine waste piles, underground workings, and unmined ore can potentially form acidic and metal-rich effluent that can enter local streams and rivers; such effluent may eventually reach Prince William Sound, which could present a problem to this local marine environment. Prior to this study, no detailed hydrogeochemical data have been collected to determine the extent of acid-mine drainage to Prince William Sound.

Stream waters from tailings versus mine adit waters.-Waters were collected within, upstream from, and downstream from mines located in three areas: LaTouche Island (Beatson, Blackbird, Duke, and Dutchess mines), Knight Island (Barnes Cove prospect and Rua Cove mine), and Port Fidalgo (Schlosser, Fidalgo, and Threeman mines) (fig. 7). The concentration of metals in surface waters collected from unmineralized areas (background concentrations) is largely controlled by the chemistry of the rocks and soils. Metal concentrations are generally low in waters collected from background sites and are 0.3 to $0.6 \mathrm{ppb}$ copper, 0.8 to $1.4 \mathrm{ppb}$ zinc, $<0.1 \mathrm{ppb}$ cadmium, $<0.5 \mathrm{ppb}$ lead, $<20 \mathrm{ppb}$ iron, and $4 \mathrm{ppm}$ sulfate. Background waters generally have $\mathrm{pH}$ values near 7 . 


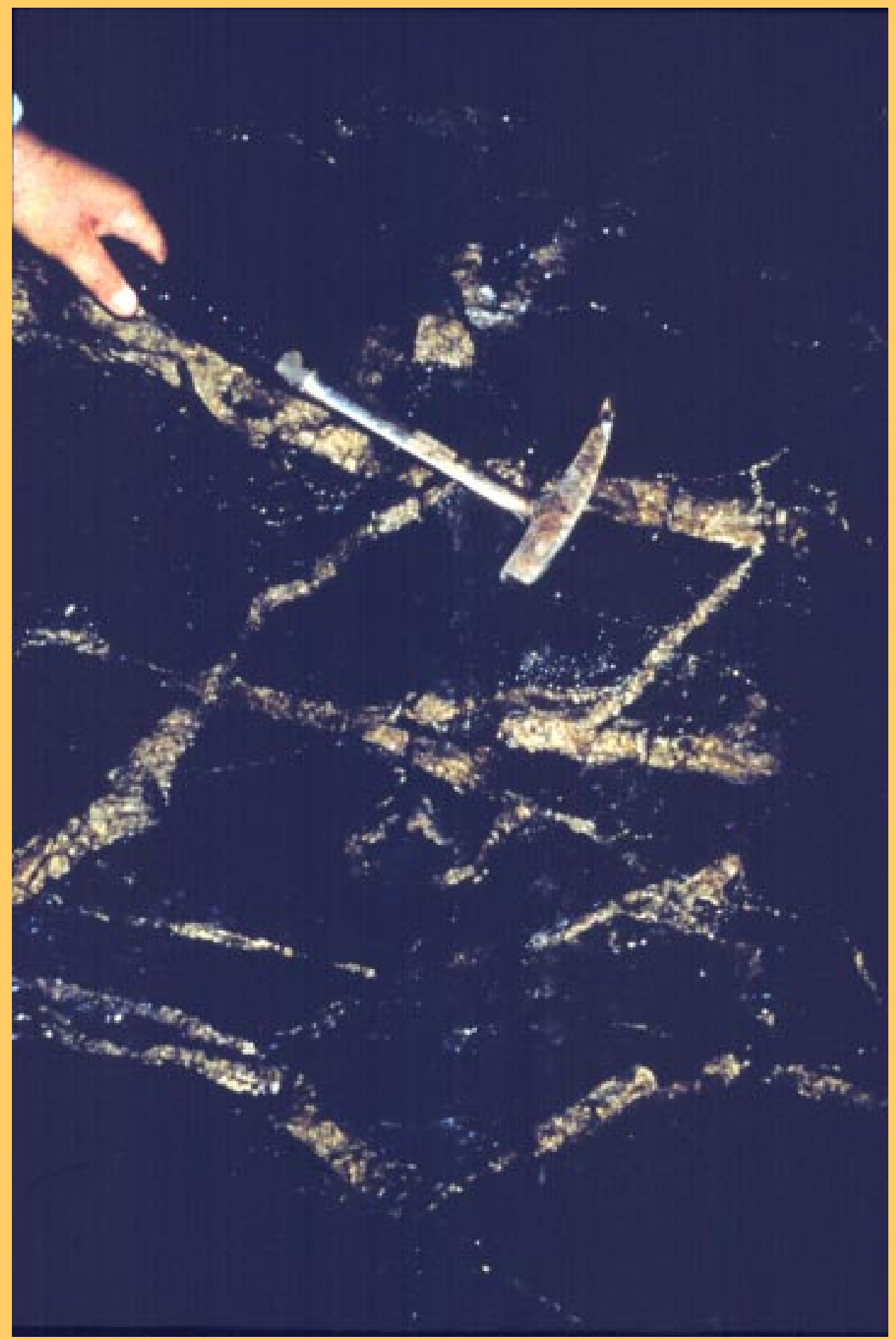

Figure 5. Mineralized rock from a volcanic-rock-hosted massive sulfide deposit showing veins with abundant chalcopyrite and pyrrhotite, Prince William Sound. 


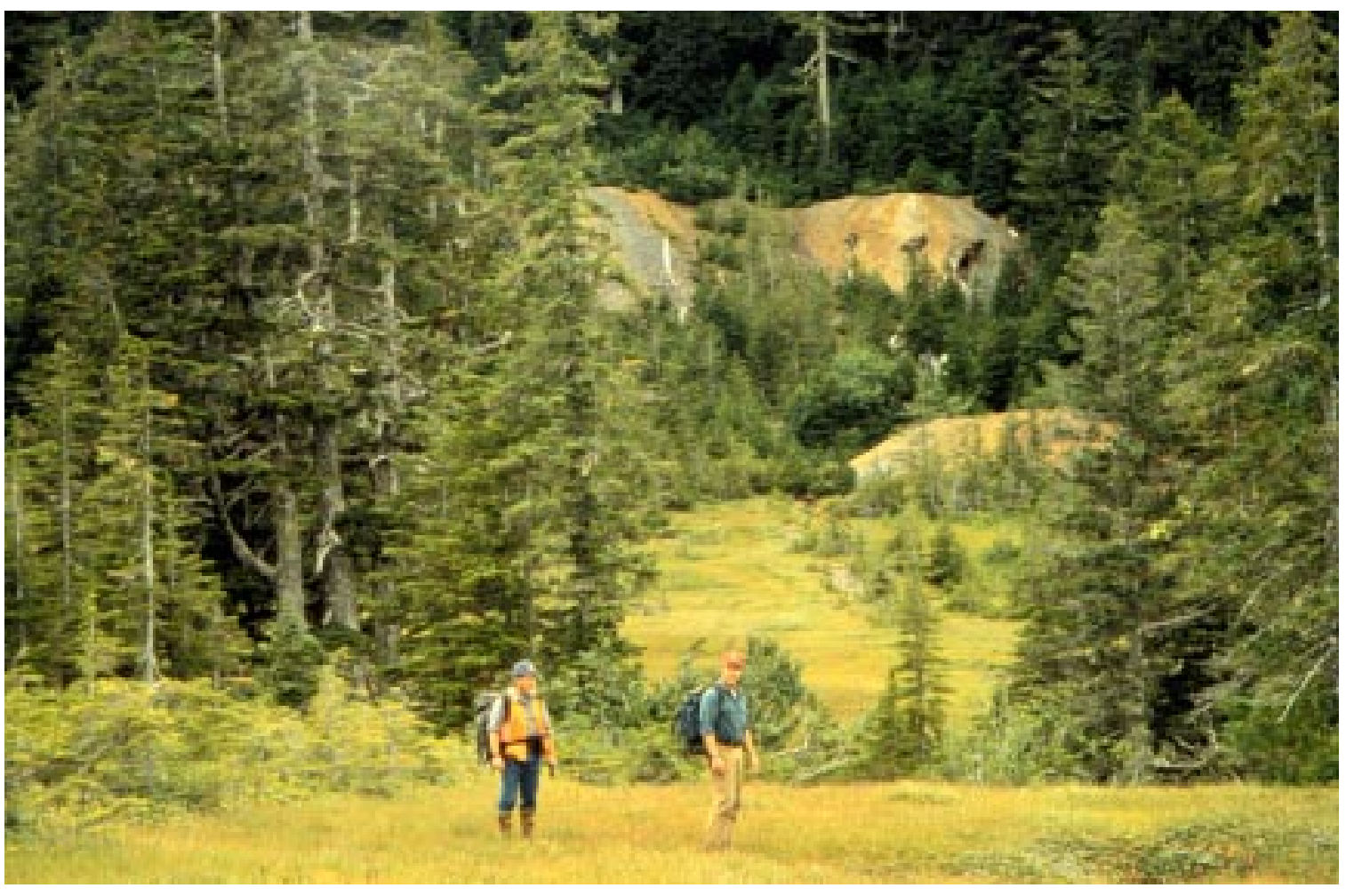

Figure 6. Abandoned tailings piles (background) near the Dutchess mine.

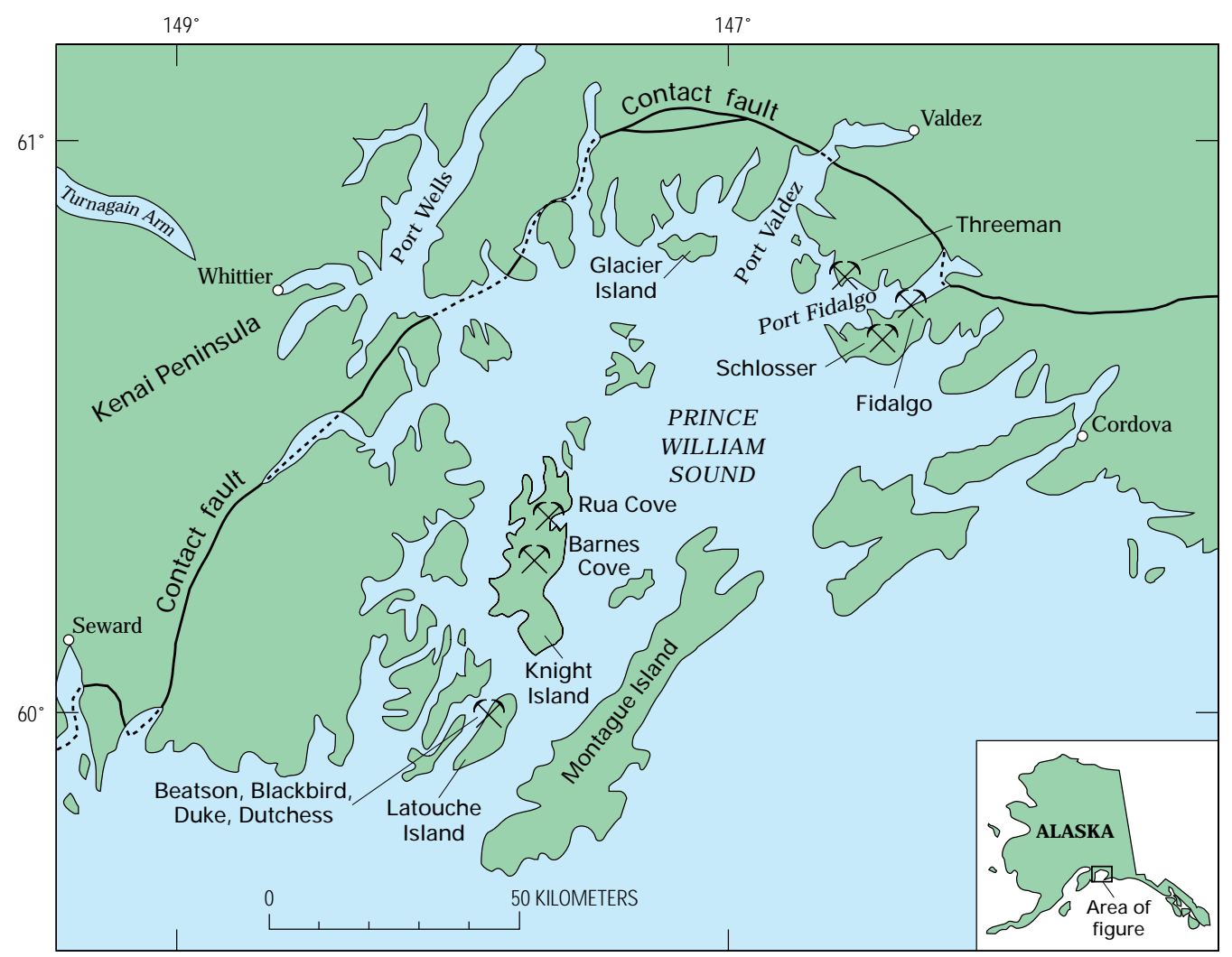

Figure 7. Location of massive sulfide deposits studied (crossed pick and hammer symbol), Prince William Sound. 
Waters containing the highest metal concentrations in the Prince William Sound area were collected from the base of tailings piles (fig. 8). These waters contain as much as $3,600 \mathrm{ppb}$ copper, 3,300 ppb zinc, 21,000 ppb iron, $220 \mathrm{ppb}$ lead, $10 \mathrm{ppb}$ cadmium, and $311 \mathrm{ppm}$ sulfate and have $\mathrm{pH}$ values as low as 2.6 (Goldfarb and others, 1996). Waters collected directly from mine adits contained lower metal contents, and $\mathrm{pH}$ values of about 6: adit waters contained as much as $1,400 \mathrm{ppb}$ copper, $3,100 \mathrm{ppb}$ zinc, $310 \mathrm{ppb}$ iron, 27 ppb cadmium, 0.9 ppb lead, and $166 \mathrm{ppm}$ sulfate, but most adit waters contained significantly lower metal concentrations. The much higher metal concentrations and acidity in waters from the tailings piles are the result of weathering of sulfide minerals in the tailings.

Acid- and metal-rich waters emanating from these massive sulfide deposits are rapidly diluted downstream by larger streams. The large streams below the mines have near-neutral $\mathrm{pH}$ values, and the amount of acid-mine drainage from the deposits is too small to affect the acidity, metal loadings, and water quality of these larger streams.

The flooded pit at the Beatson mine is about $500 \mathrm{~m}$ from the shoreline of Prince William Sound and represents a potential heavy-metal source. Water discharging from the base of the pit (fig. 9) has a pH of 6.5, and waters in the pit have a $\mathrm{pH}$ of 7.3. Such near-neutral $\mathrm{pH}$ values limit the solubility of most metals, and thus, the amount of metal that will be transported in water downstream to Prince William Sound. Water discharging from the pit contains $30 \mathrm{ppb}$ iron, $21 \mathrm{ppb}$ copper, $39 \mathrm{ppb}$ zinc, and $6.5 \mathrm{ppm}$ sulfate. Although these metal concentrations are not as elevated as those collected downstream from other massive sulfide deposits, the volume of water in the pit and the drainage emanating below the pit could deliver a large enough quantity of metal to the near-shore marine environment to possibly damage Prince William Sound.
Why do we care about massive sulfide deposits in Prince William Sound?-Many of the iron-copper-zinc massive sulfide deposits in the Prince William Sound area produce metal-rich waters as they weather. Metal concentrations and the $\mathrm{pH}$ of the acid-mine drainage will depend on a number of factors, including the amount and type of sulfide minerals present, extent of weathering, local hydrology, and the acid-neutralizing capacity of the rocks. Our studies show that on a local scale, especially where surface waters flow through tailings piles, acid-mine drainage is a concern in Prince William Sound.

Water data show that prior to emptying into major stream channels, surface waters flowing away from most of the mine workings exceed recommended EPA-CMC concentrations for copper, lead, zinc, and cadmium (table 1). Furthermore, much of the mine discharge exceeds the State of Alaska drinking water limits of $5 \mathrm{ppb}$ cadmium, 1,000 ppb copper, and $300 \mathrm{ppb}$ iron; in addition, mine effluent is often more acidic than the recommended drinking water $\mathrm{pH}$ range of 6.5 to 8.5. Therefore, at least locally, surface water may not be suitable for human consumption.

Whether any of these abandoned mines pose a threat to the downstream marine life of Prince William Sound is presently unknown. However, acid- and metal-rich waters clearly exit the base of the Beatson mine pit and drain into Prince William Sound a few hundred meters below the mine. Metal concentrations in these waters are about 10 times higher than in waters from background sites. Because marine life is especially sensitive to elevated heavy-metal concentrations, additional analysis of near-shore waters for metal enrichments is warranted. 


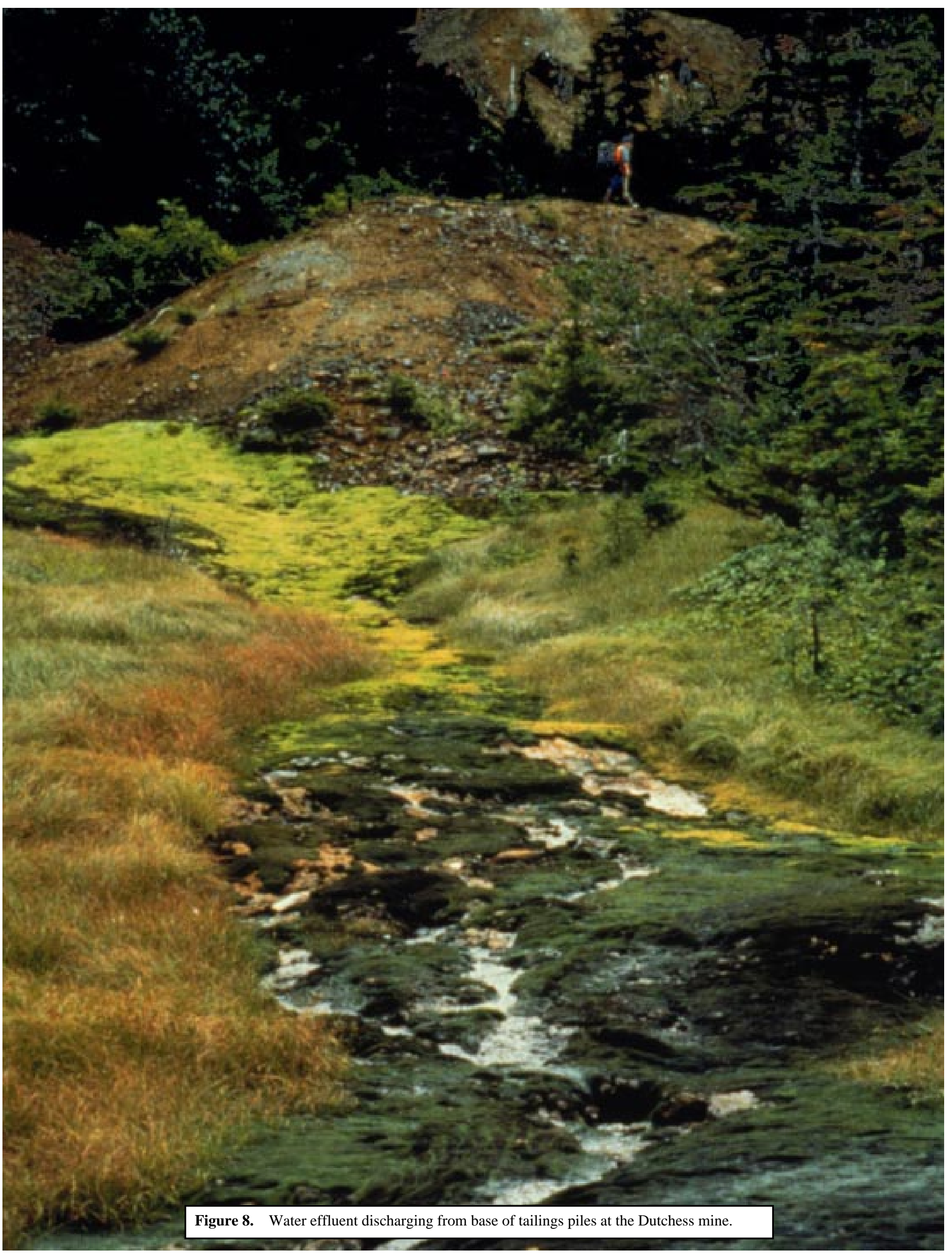




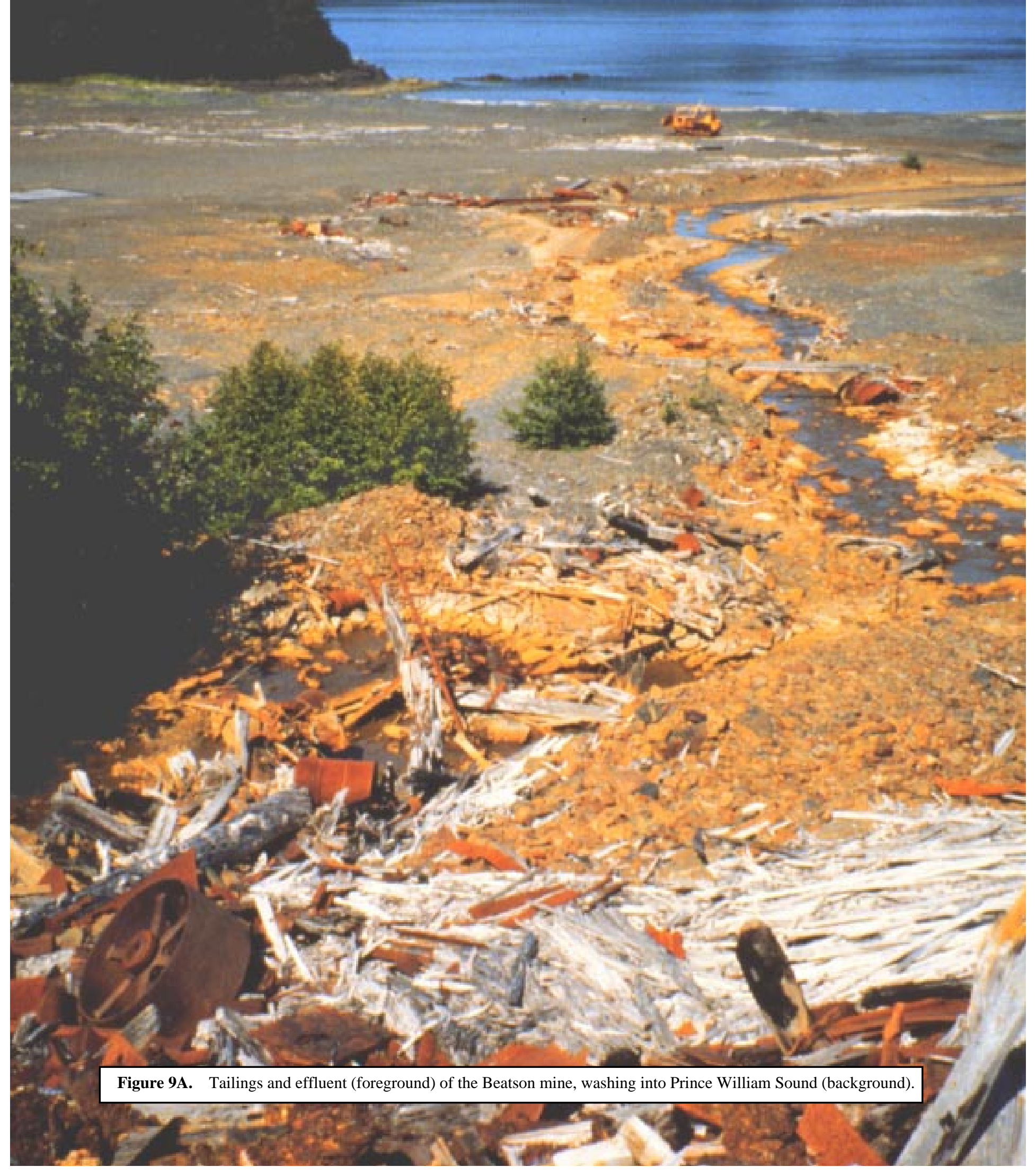




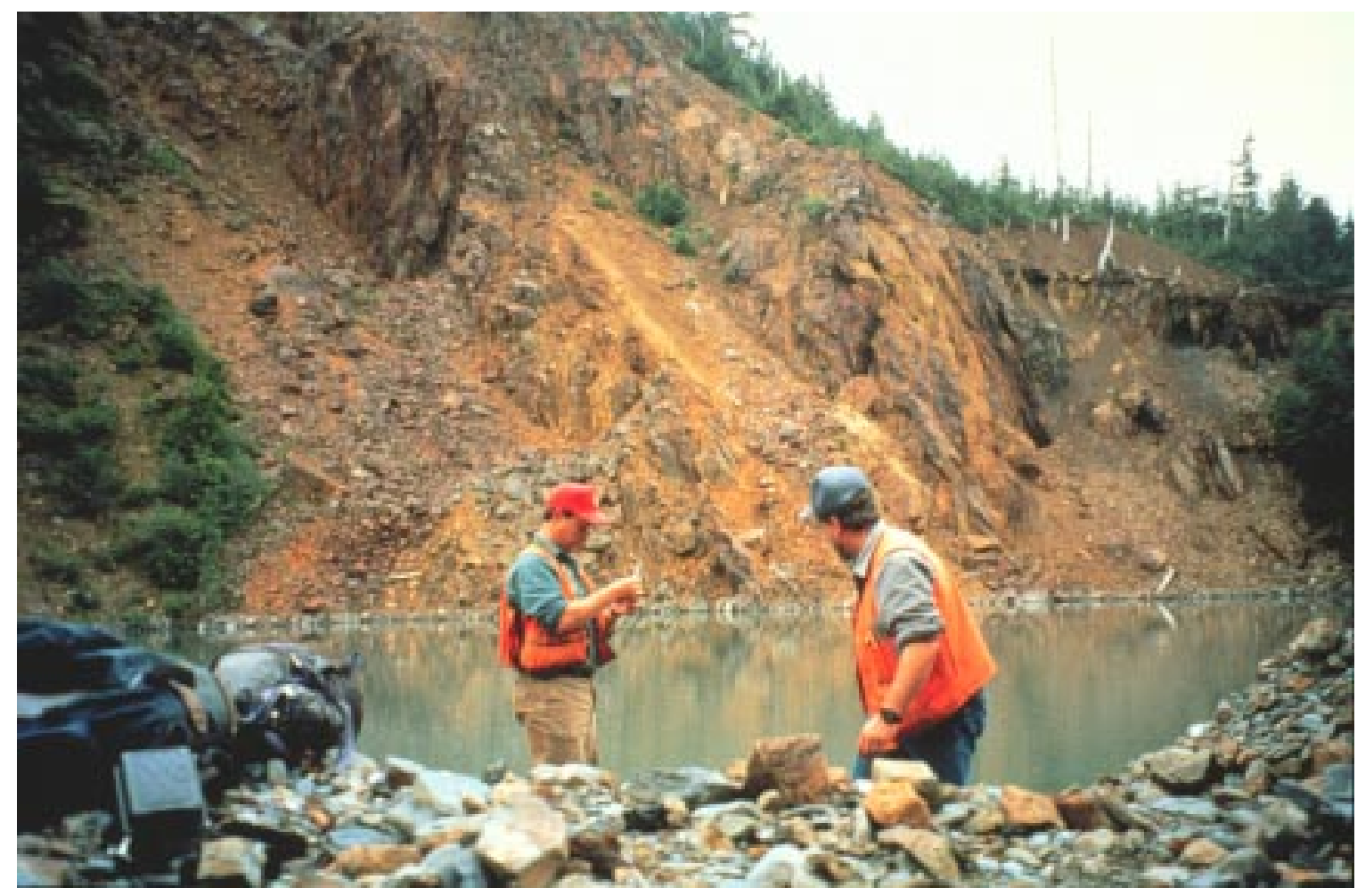

Figure 9B. View of the Beatson mine flooded pit.

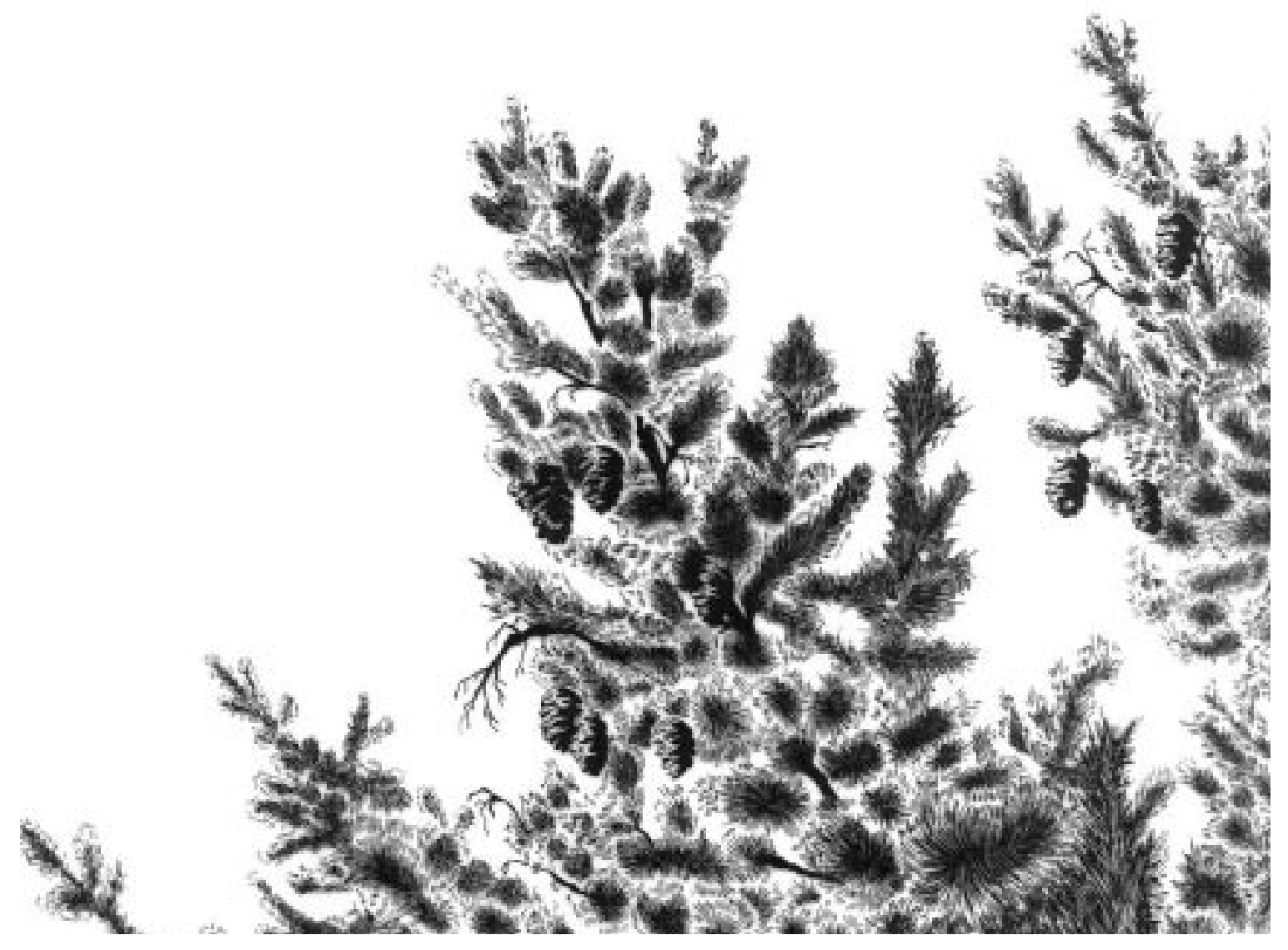




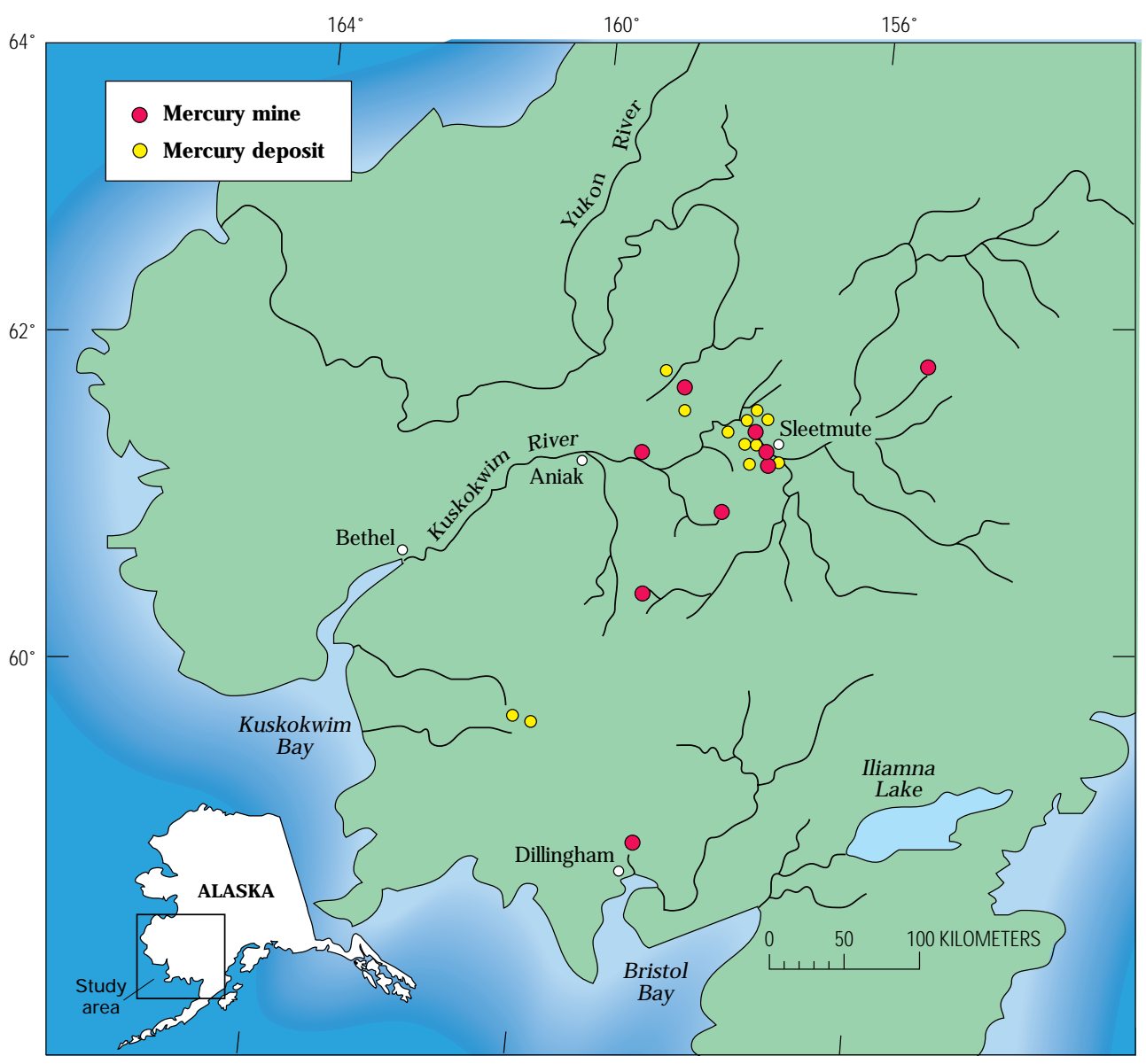

Figure 10. Location of mercury mines and deposits in southwestern Alaska.

\section{ENVIRONMENTAL GEOCHEMISTRY OF MERCURY MINES IN SOUTHWESTERN ALASKA}

Mercury-rich mineral deposits in Alaska are another type of deposit under investigation for natural and miningrelated heavy-metal concentrations in the environment. Mercury deposits are scattered over a wide region in southwestern Alaska covering several tens of thousands of square kilometers (fig. 10). The mercury sulfide mineral cinnabar is the most common mercury ore mineral in the deposits (fig. 11), but liquid mercury also occurs naturally at some localities. Several of the mercury deposits have been mined, but most of the deposits are small and undisturbed. None of the mercury mines in Alaska are currently operating, due to economic factors. Mercury is used in the manufacturing of electrical instruments, fungicides, pharmaceuticals, and munitions, in the production of paper, and in the extraction of gold (amalgamation of gold) in mining.
Should we be concerned about mercury mineral deposits in southwestern Alaska?-Mercury is a heavy metal that has no known metabolic function and is toxic to living organisms. In humans, mercury adversely affects the central nervous system and internal organs such as the kidneys. In streams and lakes, bacterial activity converts mercury in sediments from inorganic compounds (such as cinnabar) to organic forms (such as methylmercury). Organic mercury compounds are easily absorbed by organisms and are more hazardous than inorganic forms.

The primary sources of mercury are naturally occurring mineral deposits, rocks, soils, and volcanic eruptions, as well as man-made industrial sources such as factory effluents and airborne incinerations. Southwestern Alaska has no major sources of industrial mercury; however, mercury is highly concentrated around mineral deposits in the region. Thus, the presence of mercury deposits in southwestern Alaska is a potential hazard to residents and wildlife because drainage from the deposits enters streams and rivers that are part of local ecosystems (fig. 12). To evaluate the environmental concerns of these mercury deposits, the concentration of mercury was measured in sediment, water, soil, vegetation, and fish collected around some of the mercury deposits. These data were then compared with those from streams in unmineralized (background) areas. 


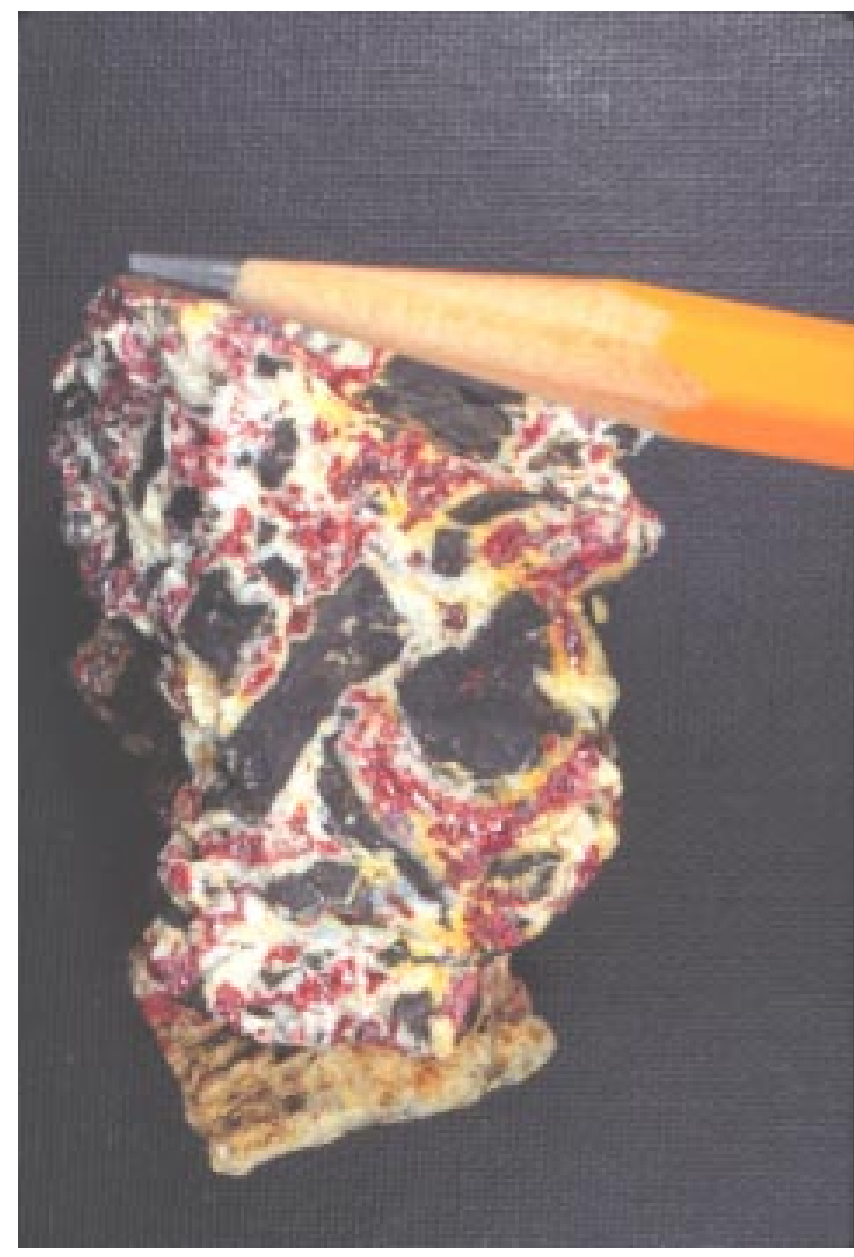

Figure 11. Rock sample containing the mercury ore mineral cinnabar (red mineral). Pencil point for scale.

Measuring mercury levels in stream sediments, stream water, and fish.-Stream-sediment samples collected near some mines contain total mercury concentrations in excess of 5,000 ppm (Gray, 1994). Stream-sediment samples collected from streams in local unmineralized areas typically contain less than $1 \mathrm{ppm}$ mercury, indicating that the samples collected near the mines are highly enriched in mercury. These high mercury concentrations in stream sediments near the mines are the result of erosion of cinnabar into the streams. Cinnabar is resistant to weathering, and thus, it remains in streams for long periods of time (fig. 13).

Stream waters below the mercury mines generally are neutral to slightly alkaline with $\mathrm{pH}$ values of about 7 to 8 . The formation of acid drainage below some mineral deposits containing sulfide minerals can be of concern; however, cinnabar is highly insoluble in water and does not easily form acid drainage during weathering. Thus, acid formation in streams below the mercury mines and deposits in southwestern Alaska is probably insignificant.
Samples of stream water collected below mercury mines contained as much as 0.75 ppb mercury, whereas background stream and river waters in the region typically contain less than $0.10 \mathrm{ppb}$. These mercury concentrations are below the $2.0 \mathrm{ppb}$ drinking water standard recommended by the State of Alaska and the $2.4 \mathrm{ppb}$ instream EPA-CMC standard (table 1).

Although cinnabar is highly insoluble in water, the water data indicate that minor amounts of mercury are converted to forms that are soluble in water, probably organic forms of mercury, that are easily absorbed by organisms, such as fish, living in the stream environment. For this reason, fish were collected throughout southwestern Alaska and analyzed for mercury to evaluate the potential for mercury to enter local food sources and the food chain. Mercury concentrations were measured in fish muscle samples (edible fillets) and livers. Maximum mercury concentrations in the muscle samples of freshwater fish collected downstream from mercury mines were about $0.6 \mathrm{ppm}$ (wet weight) and about 1.3 ppm in the liver samples (fig. 14) (Gray and others, 1994, 1996). These concentrations are considered elevated because similar fish collected from background streams in southwestern Alaska contained only about $0.2 \mathrm{ppm}$ mercury. Most of the mercury in the fish (>90 percent) was the highly toxic organic form of mercury, methylmercury. Although the fish collected downstream from the mines contain mercury concentrations higher than background levels, mercury contents in the edible portions of the fish were below the $1.0 \mathrm{ppm}$ limit established by the Food and Drug Administration (FDA).

Mercury concentrations were also measured in salmon collected from large rivers in the region because these fish are foods of local residents and sportsmen. Mercury concentrations in salmon muscle samples were low, less than $0.1 \mathrm{ppm}$ (Gray and others, 1996), well below the recommended FDA limit. These low mercury concentrations are understandable because salmon spend much of their lives in the ocean and are in contact with stream waters in southwestern Alaska only when hatching and spawning.

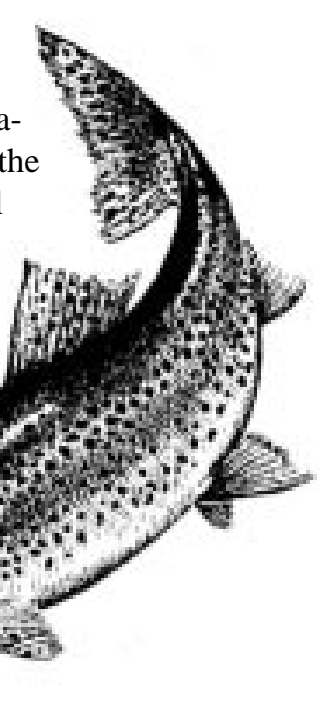




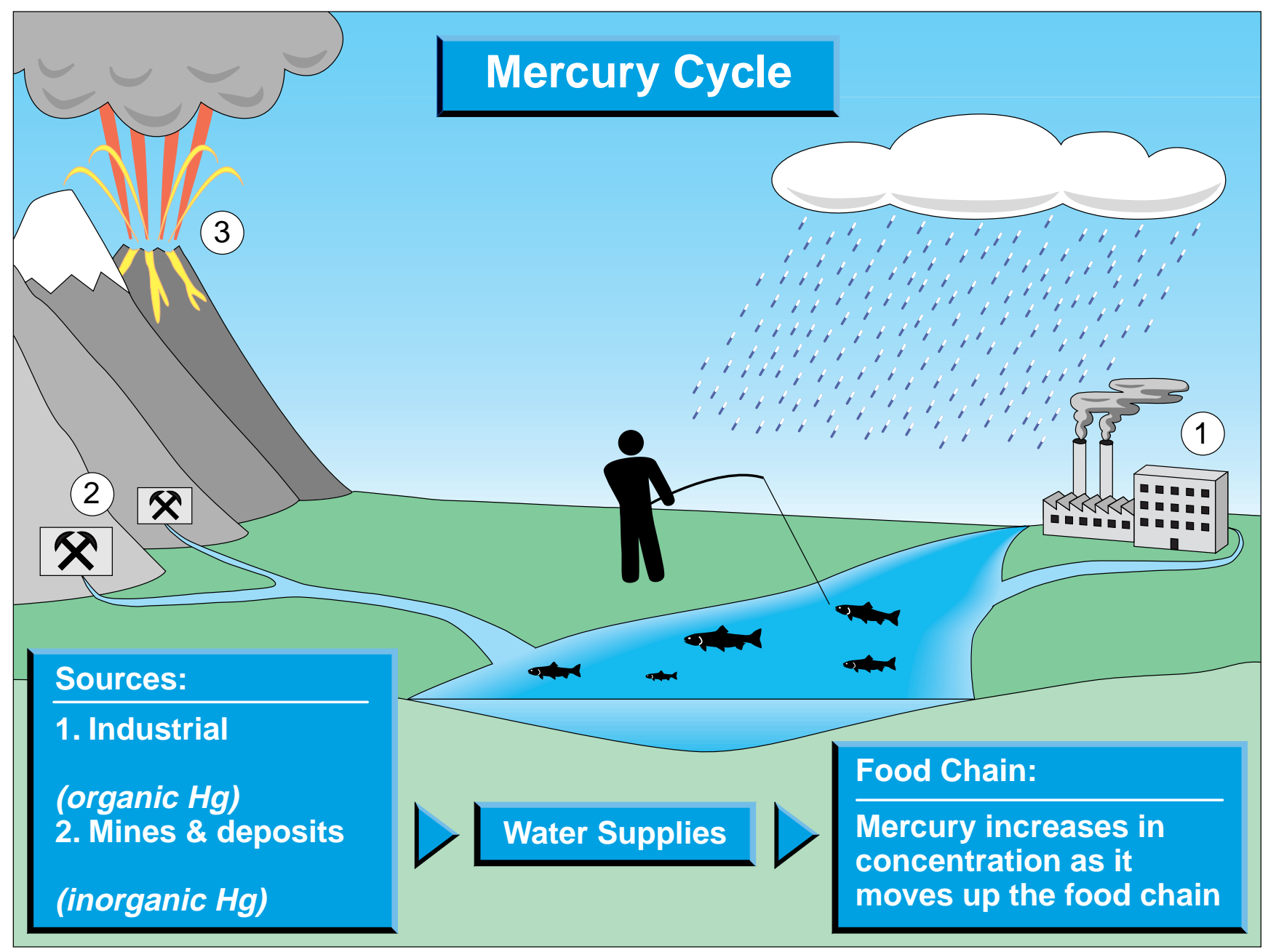

Figure 12. Schematic diagram of mercury cycle showing the most important sources of mercury-industrial, volcanoes, and mineral deposits such as those in southwestern Alaska. When mercury from mineral deposits erodes into streams, toxic mercury compounds can be absorbed by fish and eventually consumed by humans. 


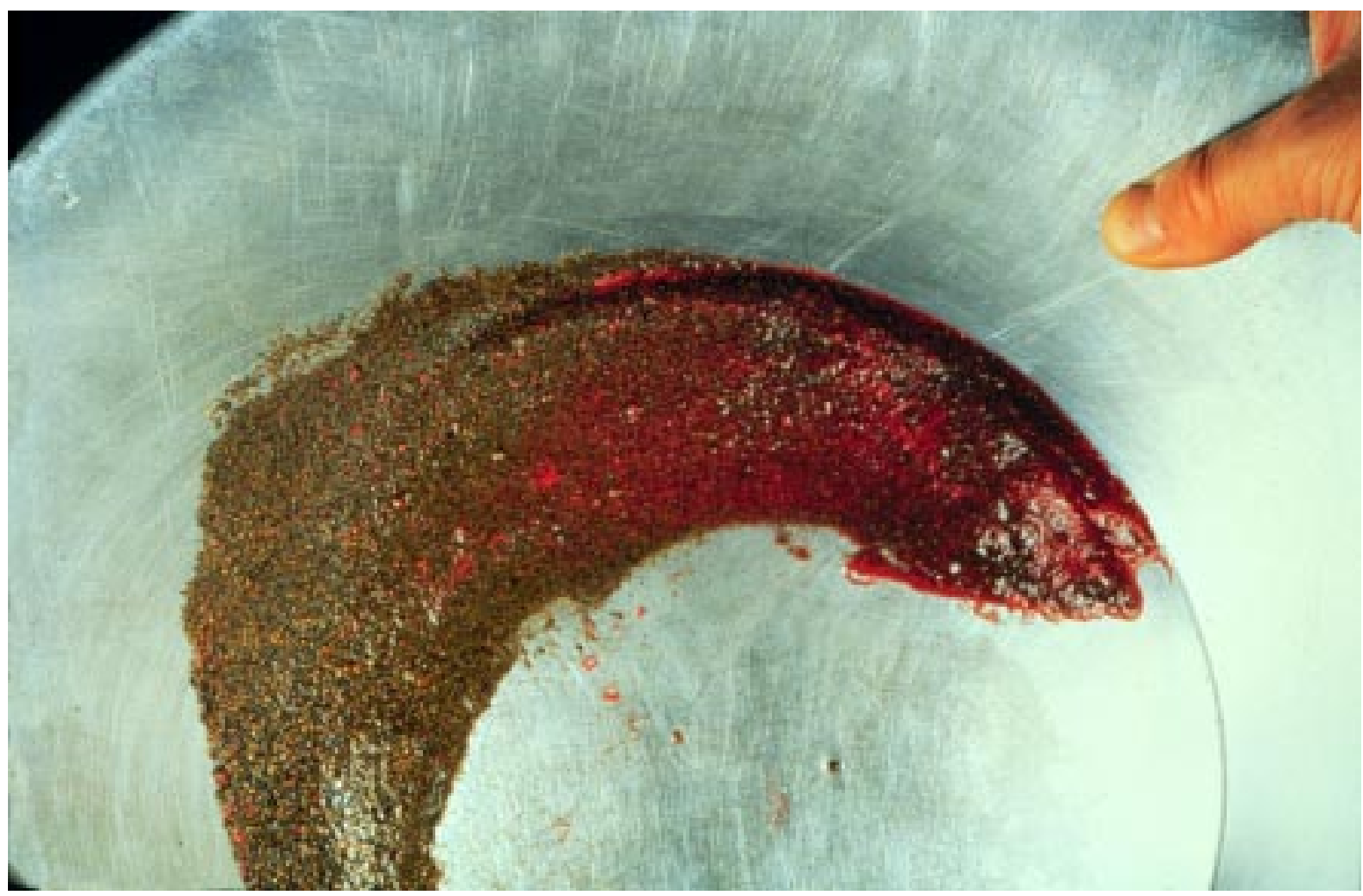

Figure 13. Heavy-mineral sample in a gold pan showing abundant cinnabar particles.

Levels of mercury in soil and vegetation around mines.-Soil and vegetation samples collected around mines also contained higher mercury concentrations than local background samples. Soils around mines contained as much as $1,500 \mathrm{ppm}$ mercury, whereas background soil samples generally contained less than 1 ppm mercury. Alder leaves collected near mines contained from 0.03 to $0.97 \mathrm{ppm}$ mercury (dry weight), compared to alder leaves from background sites containing less than $0.2 \mathrm{ppm}$. Scientists were most interested in the amount of the toxic methylmercury in plants that could be consumed by browsing animals in areas near the mines. Unlike fish, where the highly toxic methylmercury represents the large majority of the total mercury, only a small fraction of the mercury in vegetation is methylmercury, generally less than 5 percent. It is unlikely that mercury contents in such minor amounts represent a significant health concern to wildlife that consume such vegetation.
What are the answers to environmental questions about the mercury deposits?-Stream-sediment, streamwater, soil, vegetation, and fish samples collected near the mines have elevated concentrations of mercury. Cinnabar in the mines is the dominant source of this mercury. Erosion of the cinnabar around the mines results in highly elevated mercury concentrations in stream sediments, soils, and vegetation. The elevated mercury concentrations in fish downstream from the mines indicate that mercury is being converted from inorganic mercury, such as cinnabar, to organic mercury that is more biologically available. The mercury is then transferred to water and to food sources for the fish, such as larvae, insects, and other small aquatic organisms that live in the streams. Mercury or other contaminant can concentrate in tissues of organisms when it is taken up more rapidly than the organism can eliminate it, a process called bioaccumulation. When mercury enters the food chain it tends to concentrate in the highest predators, a process called biomagnification; thus, mercury concentrations in fish are useful for evaluating levels of mercury in the food chain that can eventually affect humans. The results of this study suggest that, although samples of stream sediment, water, soil, and vegetation collected near the mines contain elevated mercury concentrations, concentrations of mercury in fish indicate minor, local effects on food chains. 


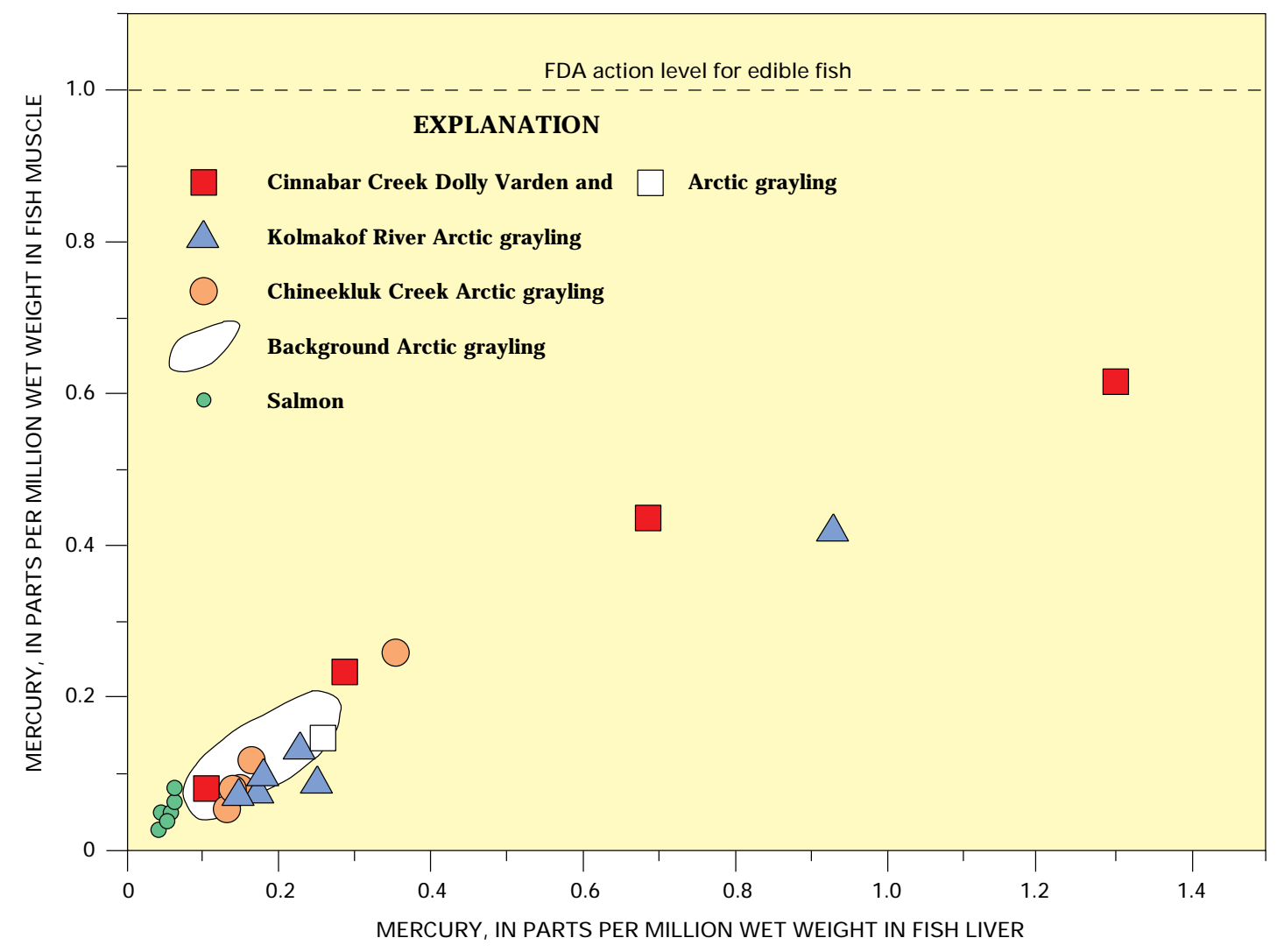

Figure 14. Plot of mercury in fish muscle versus mercury in fish liver for fish collected throughout southwestern Alaska.

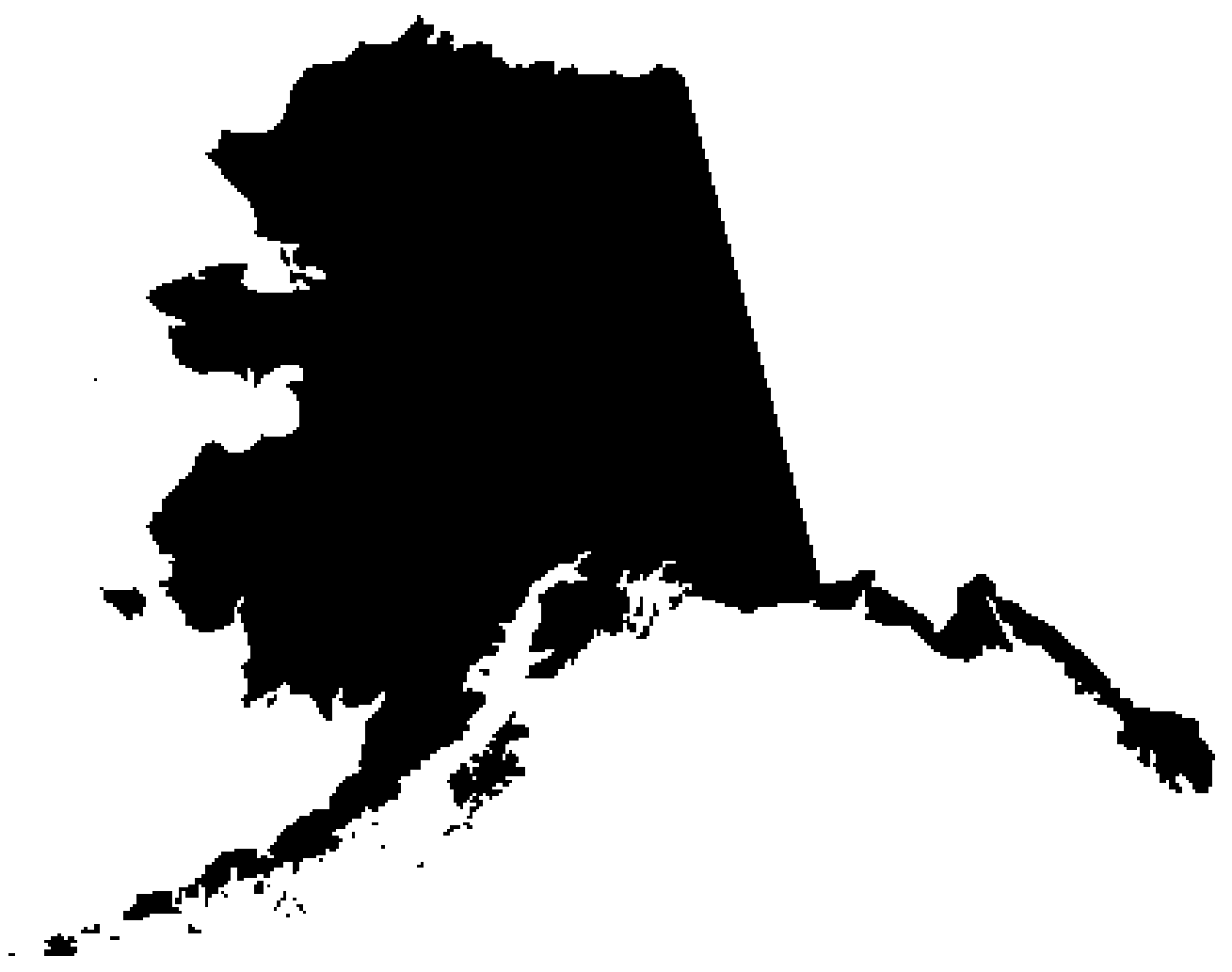




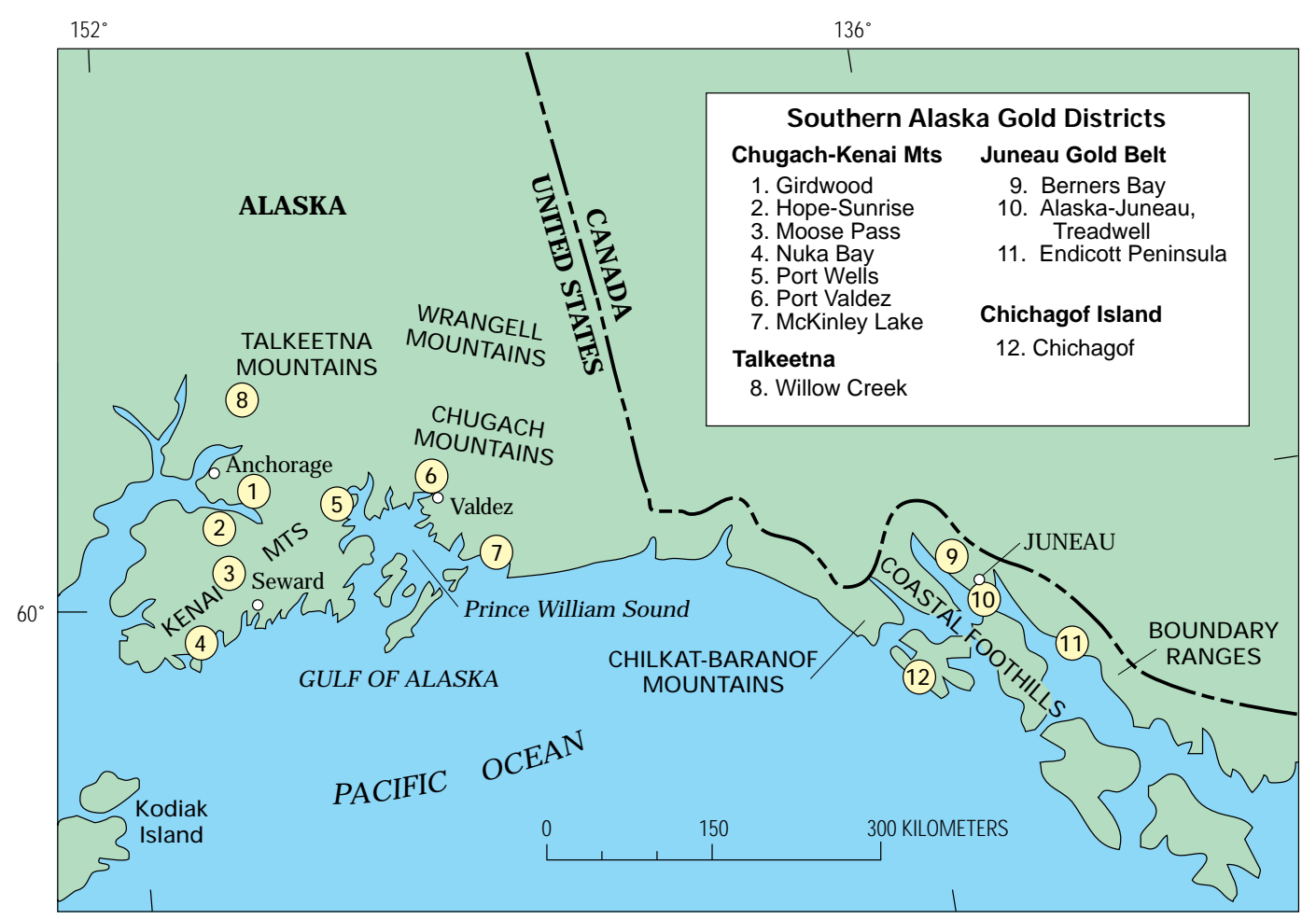

Figure 15. Location of gold vein deposits of the Pacific Gulf Coastal Forest Ecoregion.

\section{ENVIRONMENTAL GEOCHEMISTRY OF ALASKAN GOLD DEPOSITS}

Mining of gold deposits has been a major industry in Alaska since the early 1900's. Both large gold vein deposits such as the Alaska-Juneau mine, near Juneau, and large placer gold districts, such as those near Fairbanks and Nome, have been economically important in the past and will continue to be important in the future. Heavy metals such as arsenic, copper, lead, zinc, and cadmium are associated with many of the gold deposits. The following two studies evaluate environmental concerns of heavy metals in streams and rivers downstream from Alaskan gold deposits.

\section{GOLD-BEARING QUARTZ VEINS IN THE PACIFIC GULF COASTAL FOREST ECOREGION}

The Pacific Gulf Coastal Forest Ecoregion, as defined by the U.S. Forest Service, includes the coastal regions of south-central and southeastern Alaska along the Gulf of Alaska. In south-central Alaska, these lands are composed of the Kodiak Mountains, Kenai-Chugach Mountains, and the Gulf of Alaska coastal plain. In southeastern Alaska, geographic provinces of the ecoregion include the Boundary Ranges, Coastal Foothills, and Chilkat-Baranof Mountains (fig. 15).

Rocks in this region are predominantly marine sandstone and shale that are intruded by minor granitic rocks. Gold-bearing quartz veins are the most widespread mineral deposit in the region (fig. 15). The veins contain less than 3 percent sulfide minerals (fig. 16) and cut both the sedimentary and granitic rocks. The sulfide minerals are typically pyrite, arsenopyrite, chalcopyrite, galena, sphalerite, and stibnite. Calcite and other carbonate alteration minerals are adjacent to the veins. Veins range in length from a few tens of meters to more than a kilometer, with maximum widths of about $5 \mathrm{~m}$. More than 100 of these gold vein deposits were mined in the early 1900's. Mines range from open cuts and short tunnels at the smaller deposits, to large open pits (glory holes) at the largest deposits, such as the Alaska-Juneau deposit (fig. 17). 


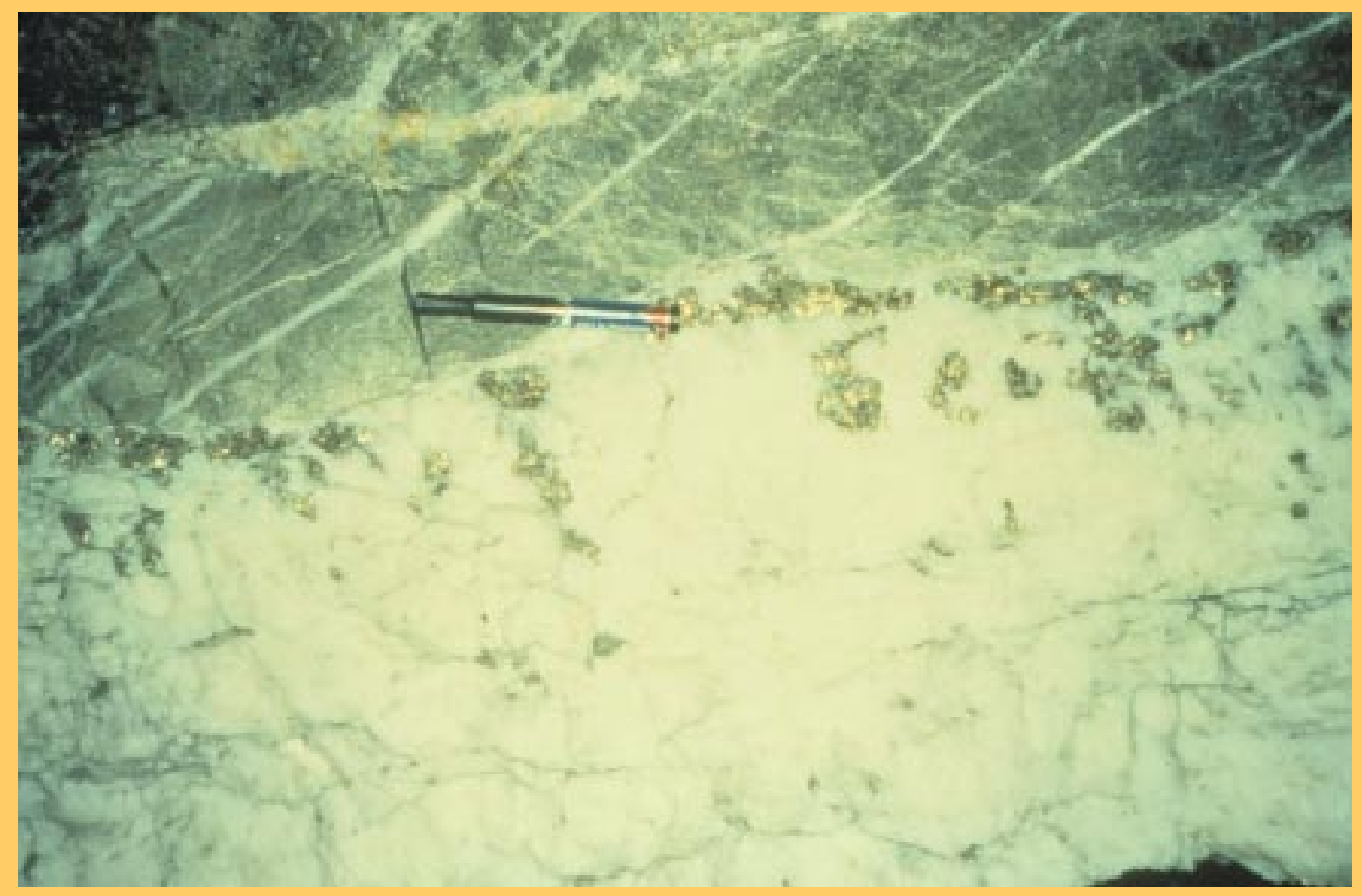

Figure 16. Vein containing quartz (white) and pyrite (brass colored). Microscopic gold is contained within pyrite grains, but because of its fine-grained nature is not visible. Felt marker for scale.

Establishing background concentrations in streams for the gold vein studies.-Background concentrations for metals in stream waters that drain unmineralized rocks were found to be $<0.05 \mathrm{ppb}$ silver, $<5 \mathrm{ppb}$ arsenic, $<1 \mathrm{ppb}$ cadmium, $\leq 1 \mathrm{ppb}$ copper, $\leq 20 \mathrm{ppb}$ iron, $<1 \mathrm{ppb}$ lead, 0.1 to 0.2 ppb antimony, 3 to $6 \mathrm{ppb}$ zinc, and 0.7 to $1.7 \mathrm{ppm}$ sulfate. The $\mathrm{pH}$ of surface waters varies from 7.2 to 7.9. Waters emanating from weathered, unmined gold vein deposits also contain low heavy-metal and sulfate concentrations. For example, in the Nuka Bay district (fig. 15, locality 4), surface waters flowing from small, unmined, gold-bearing veins contain as much as $6 \mathrm{ppb}$ arsenic and $3.6 \mathrm{ppm}$ sulfate (Cieutat and others, 1994). Concentrations of $140 \mathrm{ppb}$ iron and 4.6 ppm sulfate were measured in a large stream in the Girdwood district (Carrick and Maurer, 1994).
Testing for acid and toxic metals in waters downstream from mines.-Waters emanating from gold mines (fig. 18) have $\mathrm{pH}$ values near neutral, indicating that acid water formation is minor. The most acidic water collected had a $\mathrm{pH}$ of 6.4 , but most waters contained slightly alkaline $\mathrm{pH}$ values, similar to background surface waters collected throughout the region. Most metal concentrations in the mine waters are also similar to that of background waters. However, because pyrite and arsenopyrite are the dominant sulfide minerals found along with gold at the mines, iron and arsenic are generally the most elevated metals. In the Nuka Bay district, a maximum concentration of $130 \mathrm{ppb}$ arsenic was measured in water immediately downstream from a small vein and tailings pile. In the McKinley Lake district (fig. 15, locality 7), water-filled prospect pits contained as much as $94 \mathrm{ppb}$ arsenic and $650 \mathrm{ppb}$ iron (Trainor and others, 1996). Mine waters collected from both districts contained as much as $5 \mathrm{ppm}$ sulfate. The stream draining the Girdwood district contained $8.5 \mathrm{ppm}$ sulfate and $550 \mathrm{ppb}$ iron. 


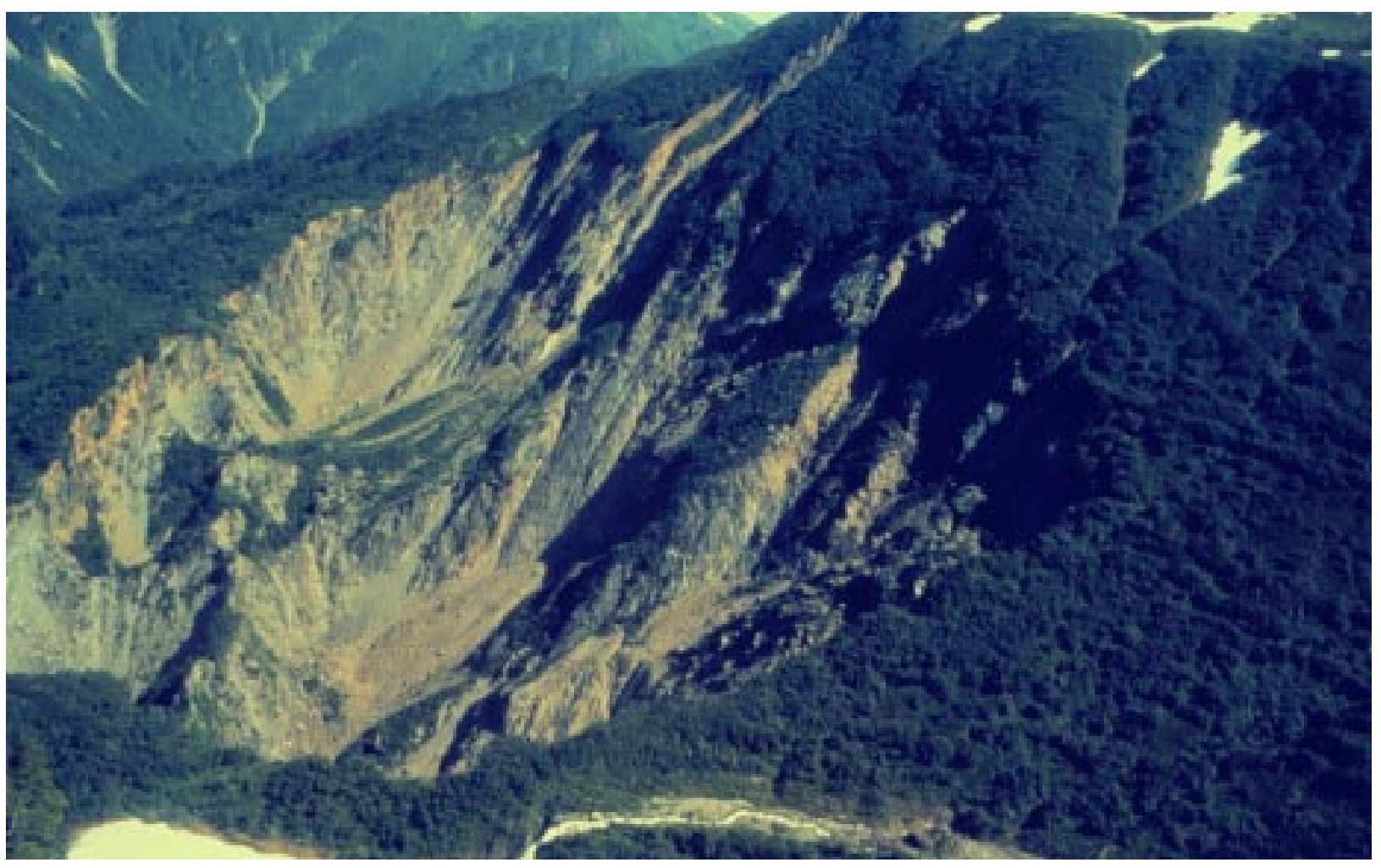

Figure 17. Open-pit cut at the largest gold vein deposit in Alaska, the Alaska-Juneau mine, near Juneau.

The Alaska-Juneau mine was the largest gold lode in Alaska, with more than $109,000 \mathrm{~kg}(3,500,000 \mathrm{oz})$ of gold produced from 1893 to 1944 . Unlike many of the other goldbearing vein deposits in the region, the Alaska-Juneau deposit contains abundant sphalerite and galena. Most mine drainage emanates from one tunnel, and this water has a measured $\mathrm{pH}$ of 8 and concentrations of $<0.5 \mathrm{ppb}$ silver, 0.6 to $2.7 \mathrm{ppb}$ arsenic, $<0.2 \mathrm{ppb}$ cadmium, $<2 \mathrm{ppb}$ copper, $<100$ ppb iron, $<2 \mathrm{ppb}$ lead, $<0.2 \mathrm{ppb}$ mercury, 39 to $52 \mathrm{ppb}$ zinc, and 230 to $340 \mathrm{ppm}$ sulfate. Except for sulfate and zinc, these data are similar to those of background waters collected from unmineralized areas.

\section{What are the environmental issues related to the gold} vein deposits?-Compared to mine-drainage waters associated with other mineral deposit types, waters emanating from gold-bearing quartz veins contain low metal concentrations due to the low abundance of sulfide minerals in these gold-bearing vein deposits and mines. In addition, carbonate minerals that form adjacent to the veins tend to neutralize the minor amount of acid produced during weathering of the sulfide minerals. Water $\mathrm{pH}$ is consequently maintained near neutral. In waters of near-neutral $\mathrm{pH}$, most metals have low solubilities and are not easily transported from the deposits. Even waters that drain Alaska's largest lode gold mine contain total base metal concentrations (copper+lead+zinc+cadmium) of less than $100 \mathrm{ppb}$.

Arsenic and iron are the most commonly enriched metals in waters emanating from mines, and their presence is related to the sulfide mineralogy of the deposits; but these metal concentrations in the waters rarely exceed the State of Alaska maximum levels for drinking water of $50 \mathrm{ppb}$ arsenic and $300 \mathrm{ppb}$ iron. Although higher concentrations have been measured in water samples from some localities, effluent throughout this ecoregion is rapidly diluted when discharged into larger stream channels. Metal concentrations in waters that drain Alaska's largest gold mine are consistently below the drinking water maximum allowable levels; only sulfate occasionally exceeds the State limit of $250 \mathrm{ppm}$. 


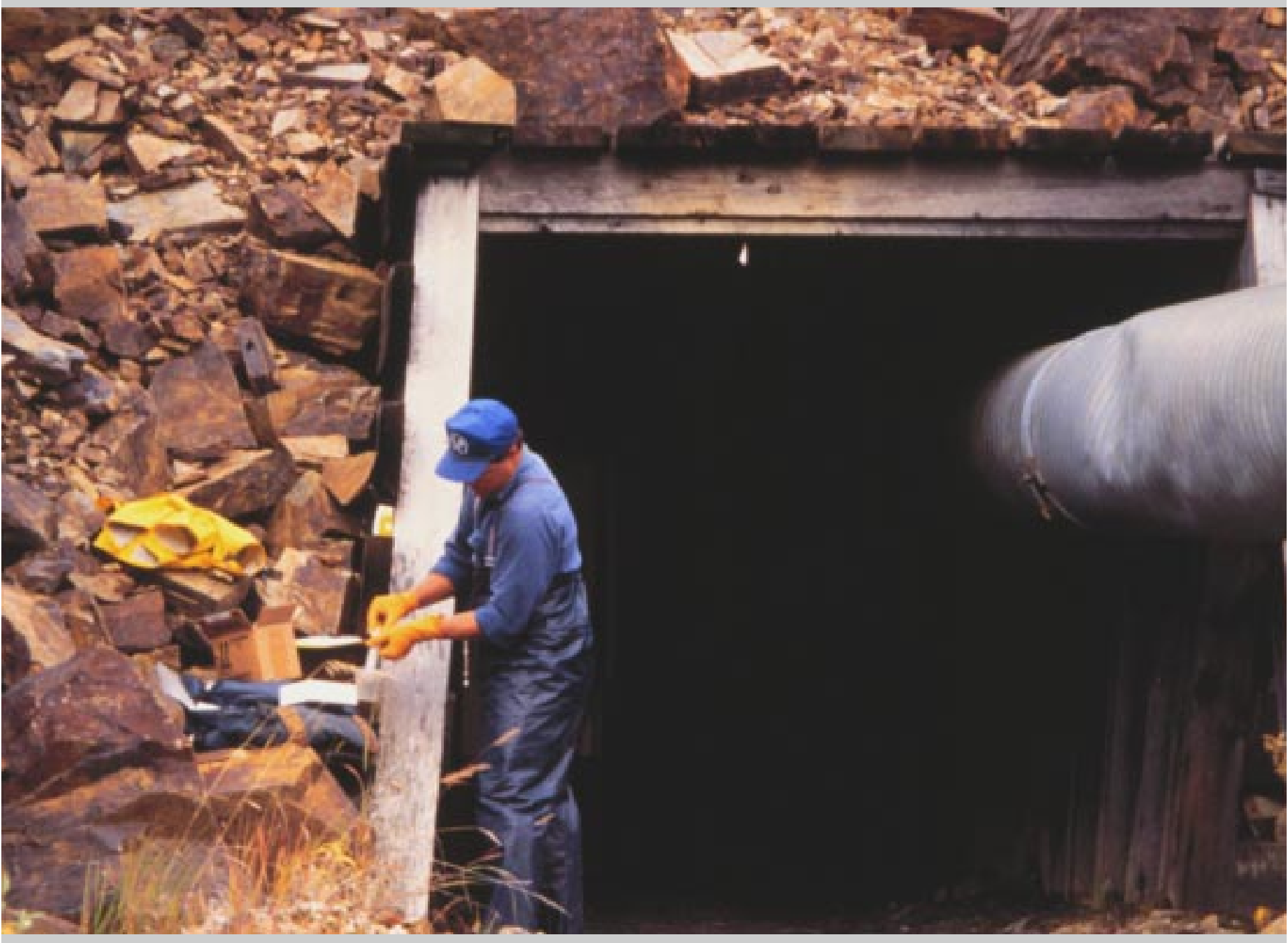

Figure 18. Sampling waters draining an adit from an abandoned gold mine in southern Alaska. 


\section{PLACER GOLD DEPOSITS OF THE FAIRBANKS AND NOME DISTRICTS}

Placer mining has been an important industry in Alaska since the late 1800's. Although some placer gold mines are currently operating in Alaska, many are now abandoned. Placer mining has produced about $730,000 \mathrm{~kg}(23,490,700$ oz) of gold, which represents more than 70 percent of all gold produced in Alaska (Swainbank and others, 1995). The two largest Alaskan placer gold districts, Fairbanks and Nome, produced about $247,000 \mathrm{~kg}(7,971,000 \mathrm{oz})$ and $149,900 \mathrm{~kg}(4,822,500 \mathrm{oz})$ of gold, respectively. Because placer mining has been widespread in Alaska (fig. 19), environmental concerns related to placer mining are addressed by evaluating the water geochemistry of samples collected from these two major gold districts.

What are placers?-Placer deposits form in stream beds, on beaches, in deltas, and in marine sediments when the action of water erodes rocks and minerals, separating heavy minerals from lighter ones. Stream placer deposits, like those in the Fairbanks district, are surficial accumulations of stream rock, gravel, and sediment containing concentrated heavy minerals (fig. 20). Beach and marine placers, like those found in the Nome district, form near the mouths of rivers, and similar to stream placers, gold and other heavy minerals are transported to the seas in rivers and streams. After the gold and stream sediment are deposited in the marine environment, ocean currents rework the sediments, concentrating the heavy minerals in deposits along beaches and in shallow marine settings. Minerals common in most placer deposits include free gold, and oxide and sulfide minerals of tin, tungsten, antimony, copper, zinc, lead, mercury, and arsenic.

During placer mining, water is used to separate gold from the sediment. During this process, the water becomes turbid and muddy. Present-day placer operations capture this turbid waste water in nearby, man-made ponds until enough of the finely suspended sediment and mud has settled out, and the water can be reused or discharged back into streams or other water bodies. Because the objective of placer mining is to remove small amounts of gold from large volumes of sediment, a significant amount of unwanted or waste material remains. This waste is com- posed mostly of rocks, boulders, coarse gravel, and other heavy minerals (placer tailings) that are commonly mounded and left in stream valley bottoms.

Environmental issues of placer deposits in Alaska.-The primary environmental concern from placer mining is the potential for the generation of acid and metalrich water, but increased water turbidity or the addition of toxic materials (such as liquid mercury) into the streams may also degrade stream water quality. Enrichment of metals in streams below placer mines can affect water quality. Heavy metals such as arsenic, copper, lead, zinc, and cadmium can be carried downstream when they are dissolved in water during weathering or can be transported downstream as fine sediment. These heavy metals can be toxic to life forms when concentrations are exceedingly high.

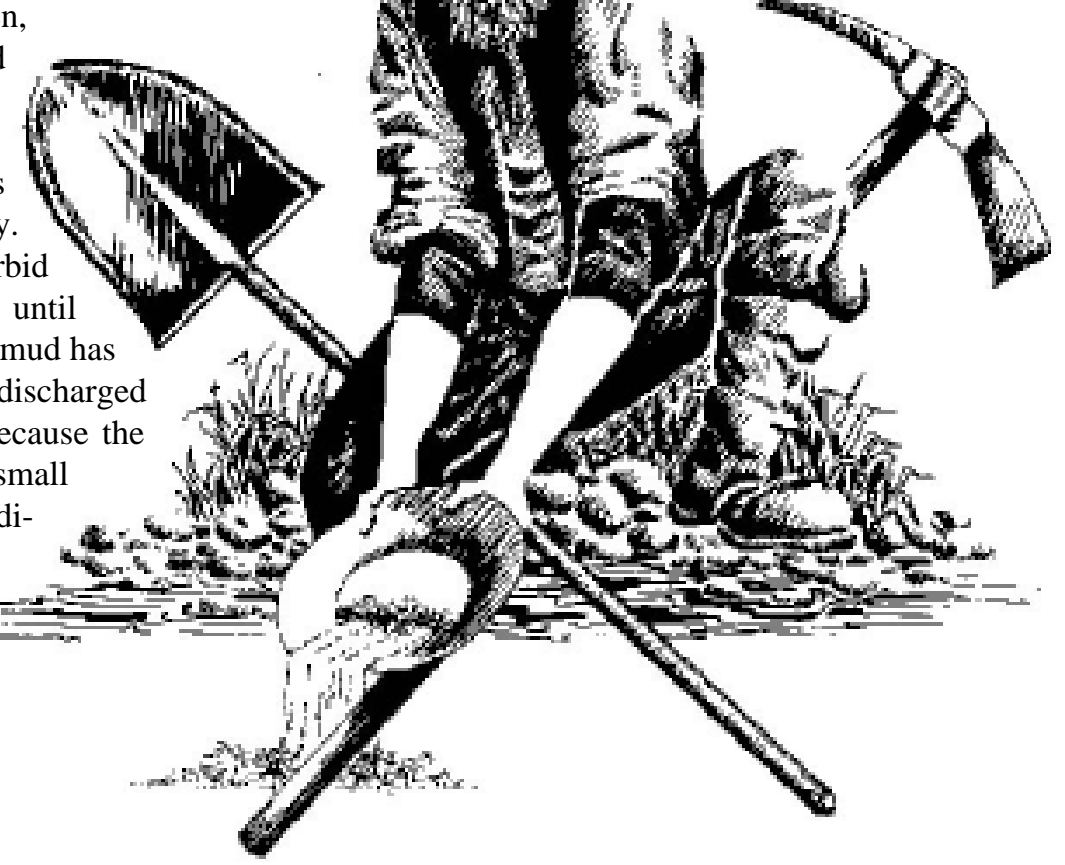




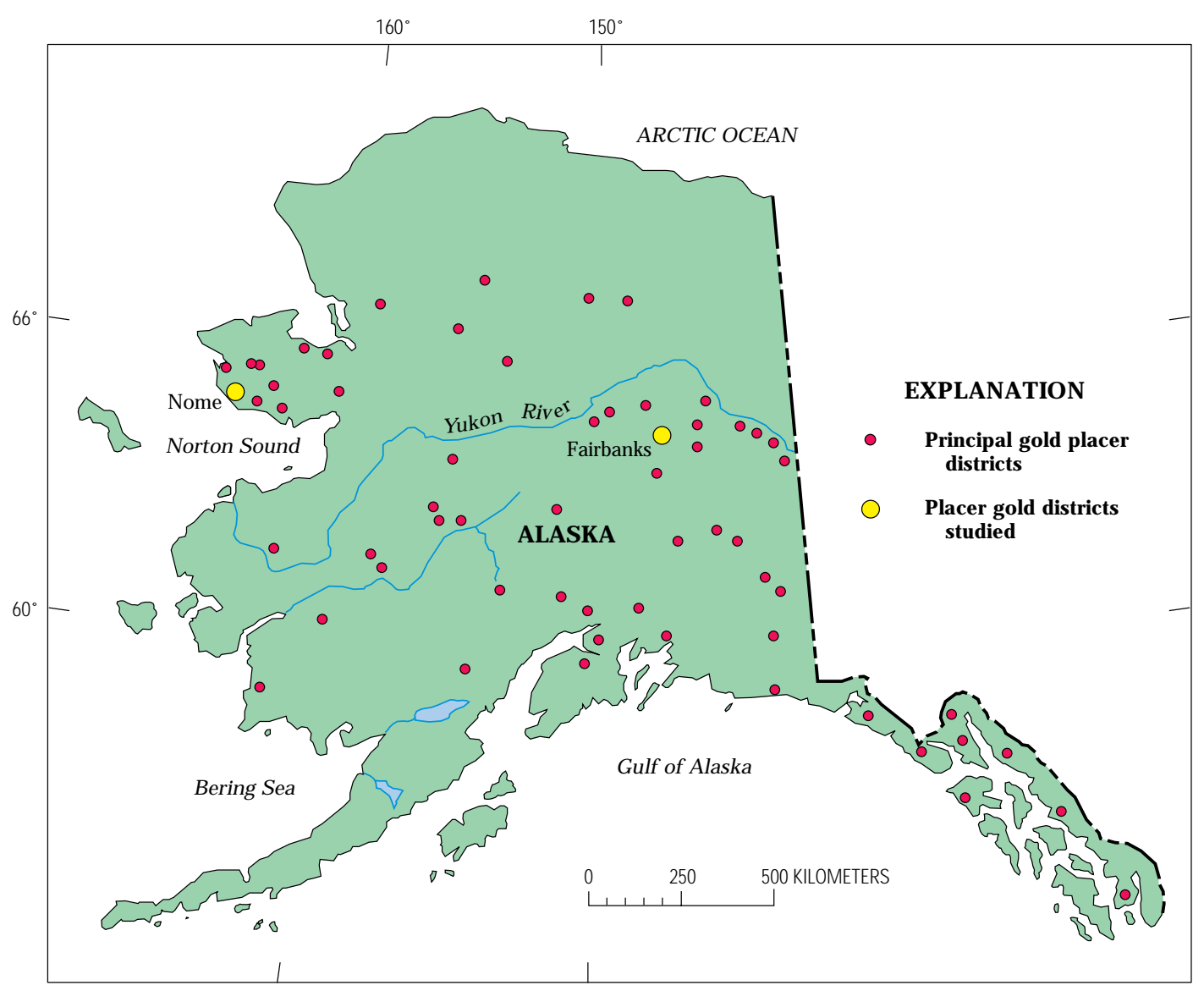

Figure 19. Location of gold placers in Alaska.

Metal concentrations in waters below placer mines.-To evaluate the adverse effects, metal concentrations in waters collected downstream from placer mines were measured and then compared to local backgrounds and State and Federal water quality standards. Stream water samples collected upstream (backgrounds) and downstream from two placer mines in the Fairbanks district (Fairbanks and Porcupine Creeks) were analyzed for arsenic, zinc, cadmium, copper, and lead to address these environmental concerns (Ray and others, 1992). Arsenic concentrations in stream waters on Fairbanks Creek range from 22 to $64 \mathrm{ppb}$ upstream, and from 62 to $112 \mathrm{ppb}$ below the placer. Arsenic concentrations in stream water samples from Porcupine Creek range from $<1$ to $15 \mathrm{ppb}$ upstream, and from $<1$ to 20 ppb below the placer deposit (Ray and others, 1992).
Of most significance are the elevated arsenic concentrations in stream waters collected below the placer on Fairbanks Creek compared to the arsenic levels in the background stream water samples. These elevated arsenic concentrations are probably related to the weathering of arsenopyrite, which is common in the placer tailings. Although the stream water concentrations of arsenic are below the EPA-CMC standard of $360 \mathrm{ppb}$ (table 1), some water samples collected from Fairbanks Creek exceed the $50 \mathrm{ppb}$ maximum level of arsenic recommended for drinking water by the State of Alaska (table 1). Acid-water formation around placer deposits in the Fairbanks district does not appear to be a significant problem because $\mathrm{pH}$ values for the two stream waters are near neutral, ranging from 6.5 to 8.1. Concentrations of other heavy metals in stream waters are below the EPA-CMC standard and appear to be of minor concern. 


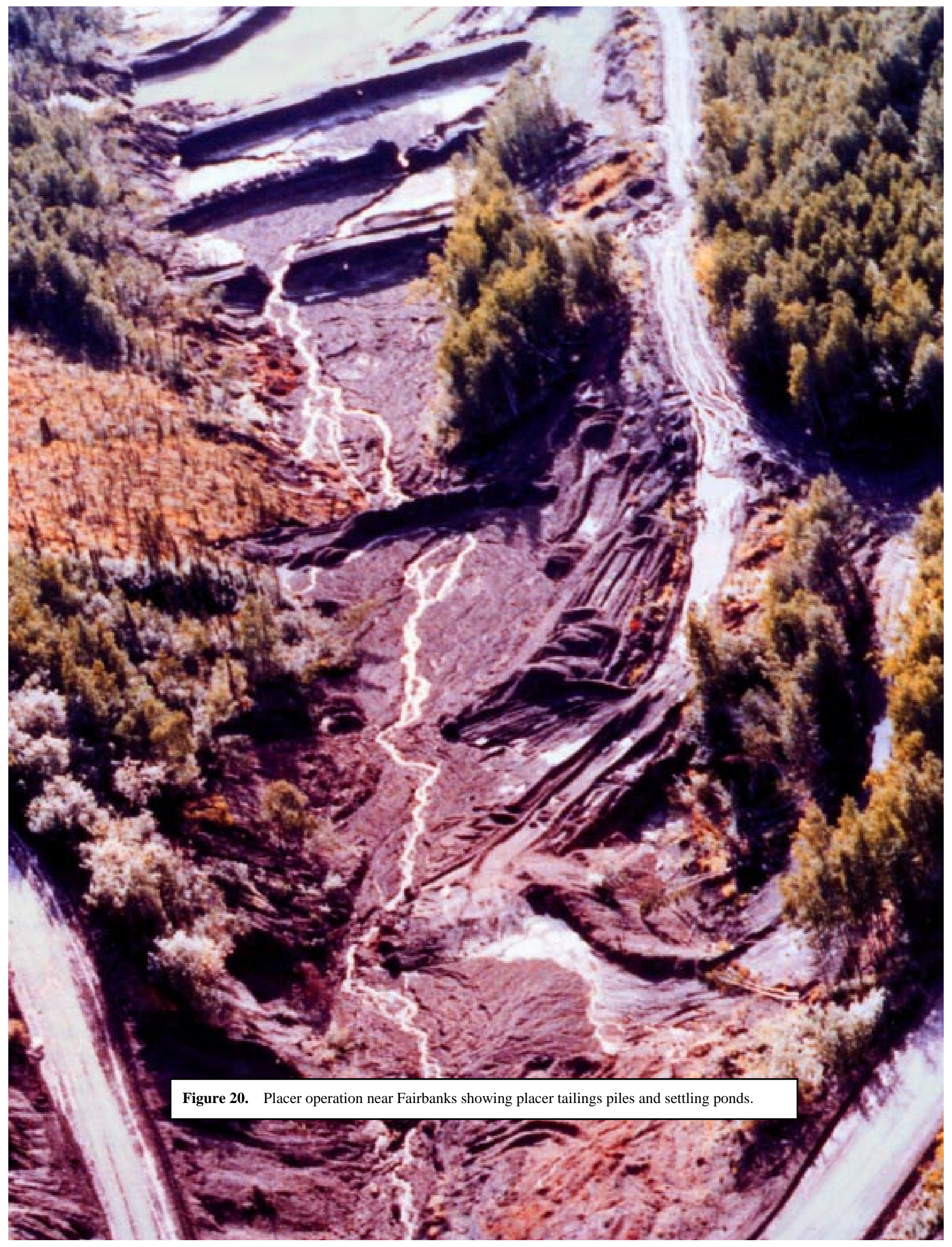


Environmental effects related to water turbidity.-Highly turbid waters often reduce light transmitted to the stream bottom, reducing photosynthesis. Excessively turbid waters can smother plant life, destroy habitats for benthic organisms, and clog the gills in fish. Prior to the mid 1980's, waste water was not held in settling ponds, but was often discharged directly back into streams. Today, turbid water discharges from placer operations are closely monitored, and the downstream effects are generally fairly minor.

Mercury introduced during placer mining.-Liquid mercury has been used for the extraction of gold (amalgamation of gold) for many years. Amalgamation of gold has been most often used in placer operations because often the gold is fine grained. Although gold amalgamation is rarely used today, some liquid mercury may remain in streams near old placer operations because it was sometimes spilled, lost, or discarded.

During the 1980's and 1990's, high concentrations of mercury and other heavy metals were found in marine waters near the Nome placer deposits. Mercury concerns scientists the most because it is toxic to life forms and can enter the food chain and affect the health of wildlife and humans. Mercury concentrations in seawater collected near the Nome placer district ranged from $<0.05$ to $0.48 \mathrm{ppb}$ (U.S. Minerals Management Service, 1989). Although these mercury concentrations are considered high for seawater, they are below the $2.1 \mathrm{ppb}$ EPA-CMC standard for seawater (table 1). The source of mercury was traced to upstream sources of cinnabar and liquid mercury used for gold amalgamation in the area (U.S. Minerals Management Service, 1989).
Conclusions of the placer studies.-Placer deposits contain minerals with heavy metals that are potentially toxic to humans and wildlife, but water quality degradation downstream from placer mines is relatively minimal. For example, although arsenic concentrations in stream waters sampled below placers in the Fairbanks district exceed the State drinking water standard, these arsenic concentrations are also below the EPA-CMC standard. In addition, acid-water formation below placer deposits in the Fairbanks district is minor because measured water $\mathrm{pH}$ is generally near neutral. Mercury concentrations in seawater near the Nome placer district are higher than in typical background seawater, but are well below the EPACMC standard. Most other heavy-metal concentrations in waters near the placers studied here are low and of minor concern. Continued study of the environmental effects of placer deposits is important, especially in streams that support wildlife, or in populated areas.

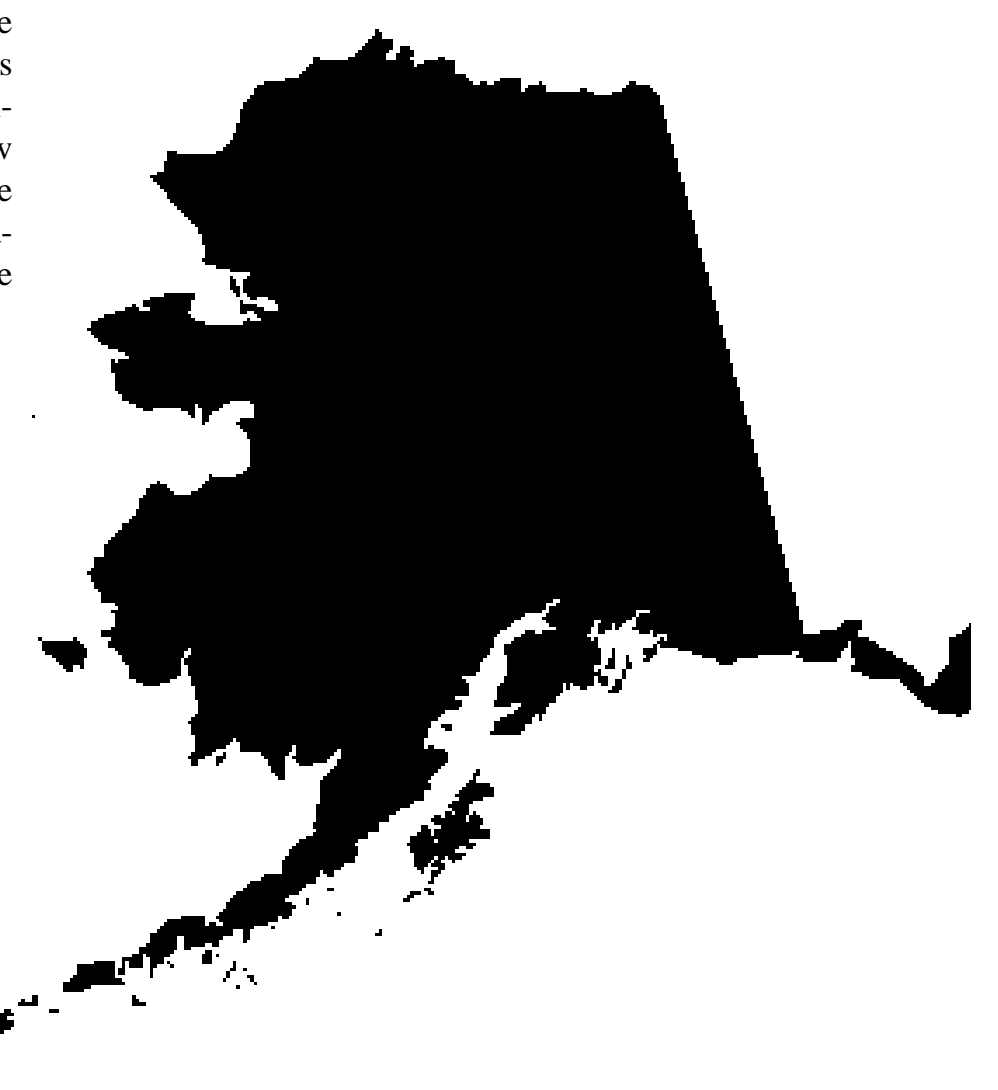




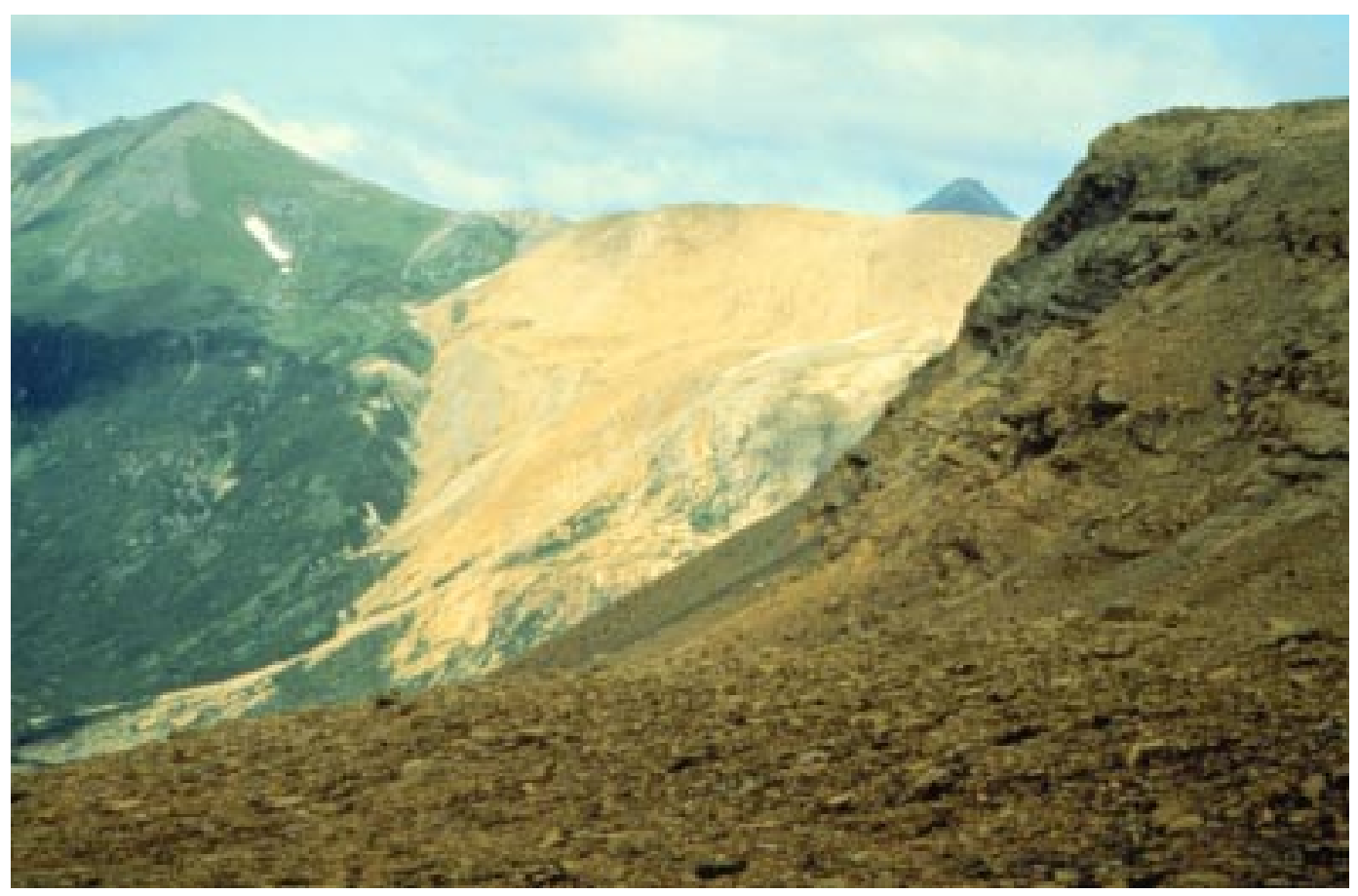

Figure 21. The Red Mountain chromium deposit, showing the color and vegetation contrast between the bare, light-orange ultramafic rock (center background), and vegetated soil (left background).

\section{GEOCHEMISTRY OF SURFACE WATERS DRAINING ALASKAN CHROMITE DEPOSITS}

Most of the world's chromium is found in ultramafic rocks. These ultramafic igneous rock complexes consist of dark, layered rocks that are rich in silica, magnesium, iron, and calcium, as well as the mineral chromite. These ultramafic rocks generally weather to an orange-brown color due to the formation of iron oxides, and these rocks typically do not support vegetation (fig. 21). Chromium ore consists of black layers or seams that are rich in chromite. Although these seams vary in thickness from the width of a few chromite grains to nearly $2 \mathrm{~m}$, only thick seams are mined (fig. 22). Chromium is used in the manufacturing of steel alloys, metals plating, pigments and dyes, wood preservatives, and as a catalyst in chemical processes.
There are several chromite deposits throughout Alaska that are associated with ultramafic rocks. USGS scientists studied two of these chromite-bearing occurrences (fig. 23). Red Mountain, located $16 \mathrm{~km}$ from the town of Seldovia, was the largest chromite mine in Alaska, where over 35,000 $\mathrm{t}$ of chromium ore was recovered through 1976. Drainage from the Red Mountain mine enters streams that eventually run into a saltwater fishery in Kachemak Bay. Siniktanneyak Mountain (fig. 23), in the western Brooks Range, was the site of USGS study of a second, small, unmined chromite seam. At both locations scientists collected water samples downstream from the mineralized areas (fig. 24), as well as from local unmineralized (background) areas to determine water $\mathrm{pH}$, chromium concentrations, and other major- and trace-metal concentrations. 


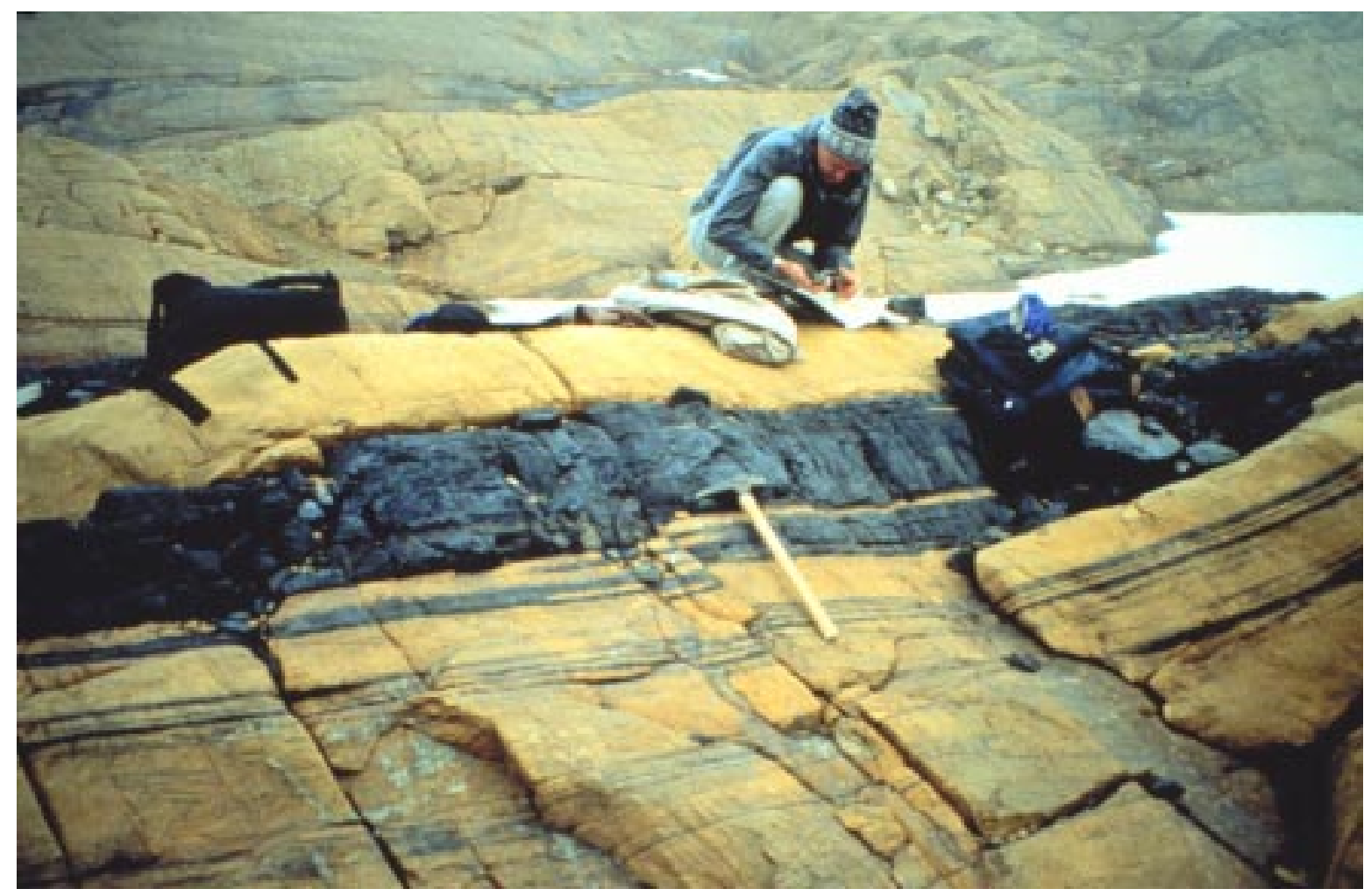

Figure 22. Photograph showing a $60 \mathrm{~cm}$ thick seam of black chromite ore layered within the ultramafic rocks at Red Mountain.

Potential hazards related to chromium deposits.-Weathering of ultramafic rocks produces two types of surface waters (Barnes and O'Neil, 1969). The most common type is alkaline with $\mathrm{pH}$ values of about 8.3 to 8.6 and is enriched with magnesium bicarbonate. The second and much less common type is a highly alkaline, calcium hydroxide water with $\mathrm{pH}$ values of about 11.2 to 11.8. Because most chromium deposits are found in ultramafic rocks, it is important to understand how waters flowing from such rocks interact with chromite. Although chromite is resistant to chemical and physical weathering and highly insoluble in near-neutral surface water, in some cases, small amounts of chromium can be found in water as either a trivalent or the highly oxidized hexavalent form (Hem, 1992). Trivalent chromium is the dominant form in most surface waters, but in highly oxygenated, alkaline waters of $\mathrm{pH}$ greater than 9, hexavalent chromium predominates. This hexavalent chromium poses the most environmental concern because it is toxic to humans and animals (Simon and others, 1994).
Chromium concentrations in surface waters draining the Alaskan deposits. - Waters flowing from the two Alaskan chromite localities studied are the alkaline, magnesium bicarbonate type. Measured $\mathrm{pH}$ values of 7 to 8 at both deposits indicate that the streams draining the deposits are neutral to slightly alkaline. Stream water samples collected downstream from the Red Mountain mine contain between 0.5 and $1.0 \mathrm{ppb}$ chromium, well below the State of Alaska drinking water standard of $100 \mathrm{ppb}$ (table 1). Water samples collected downstream from the Siniktanneyak locality contain chromium below the $0.5 \mathrm{ppb}$ lower limit of determination. Other heavy metals measured in the waters, such as nickel, copper, lead, and zinc, are also below drinking water standards and similar in concentration to waters collected from background sites. 


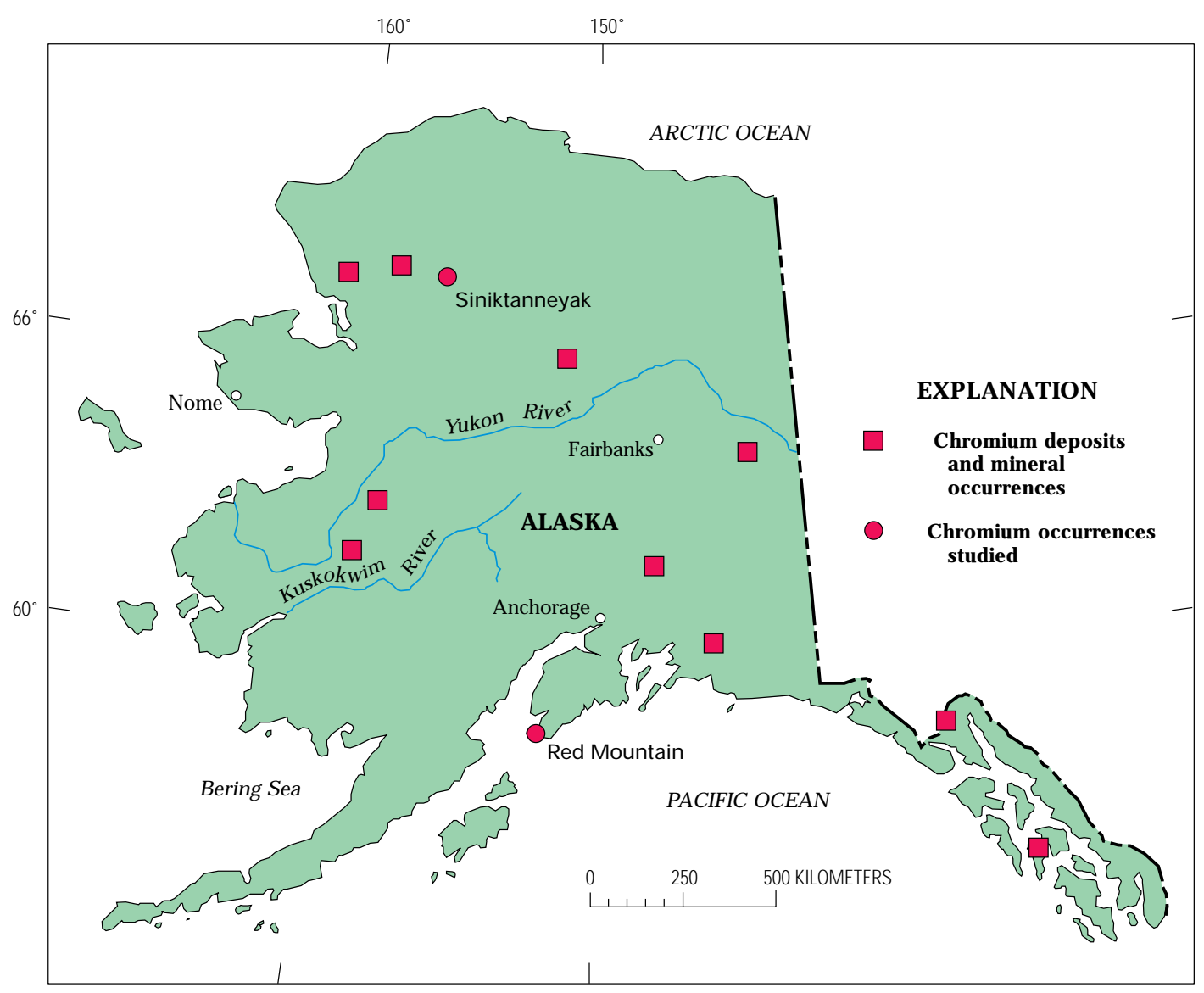

Figure 23. Location map of the Alaskan chromium occurrences studied.

Stream waters contain low concentrations of chromium.-The low chromium concentrations in waters collected from the Red Mountain mine and the Siniktanneyak Mountain complex are consistent with the low solubility of chromium in slightly alkaline surface water. Concentrations of trivalent and hexavalent chromium were not determined in these studies because the total chromium contents of the waters were low and because the water $\mathrm{pH}$ values were below 9. Such waters are unlikely to contain chromium in the toxic hexavalent form. Results for these two Alaskan chromite deposits suggest no adverse effect on the quality of waters emanating from the deposits. In addition, chromium concentrations entering streams below the Red Mountain deposit are probably not high enough to adversely affect the fishery near Seldovia, although chromium accumulation in bottom sediments and possible transference to fish were not evaluated. 


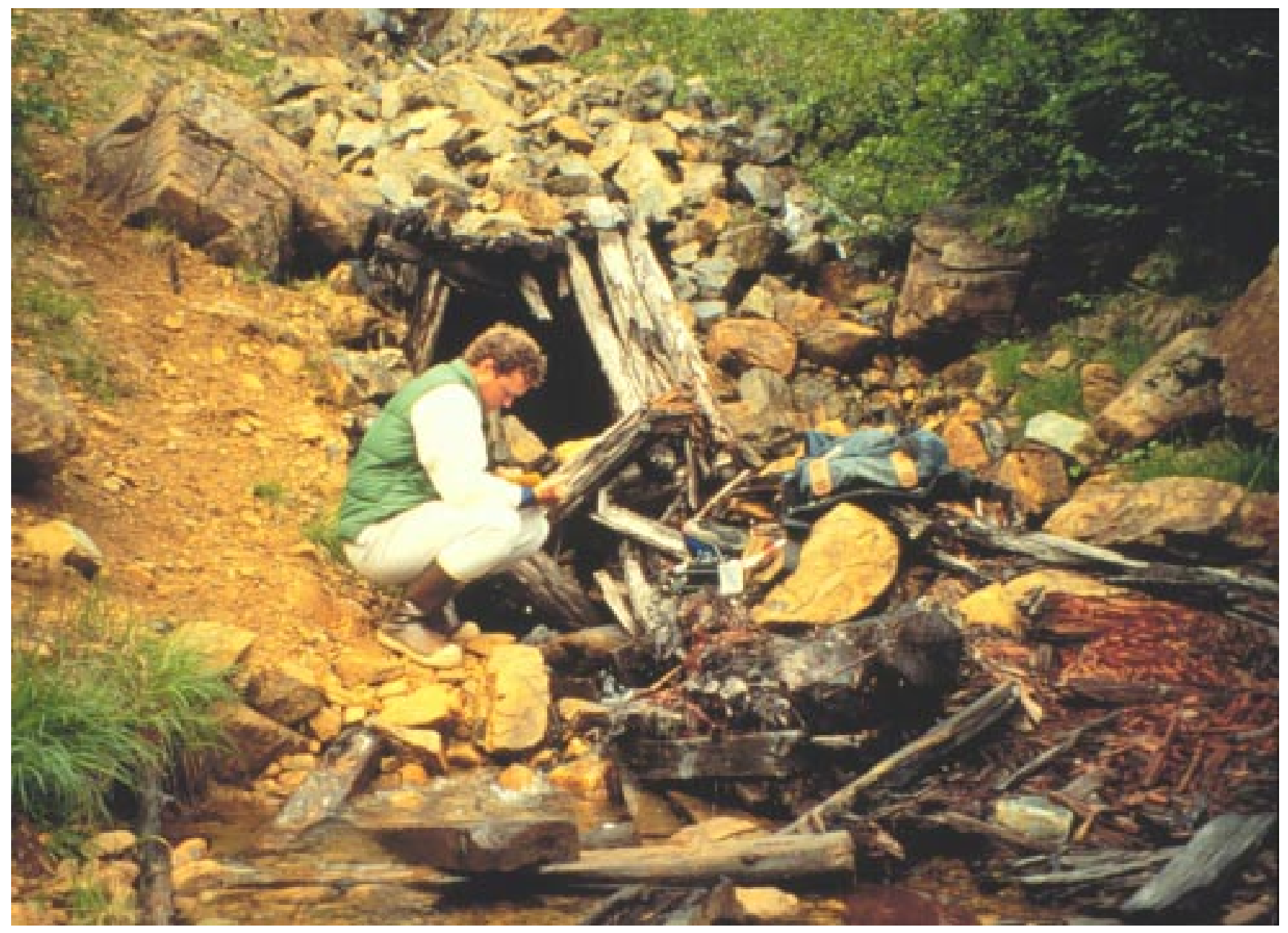

Figure 24. Water flowing from an adit of an abandoned chromium mine.
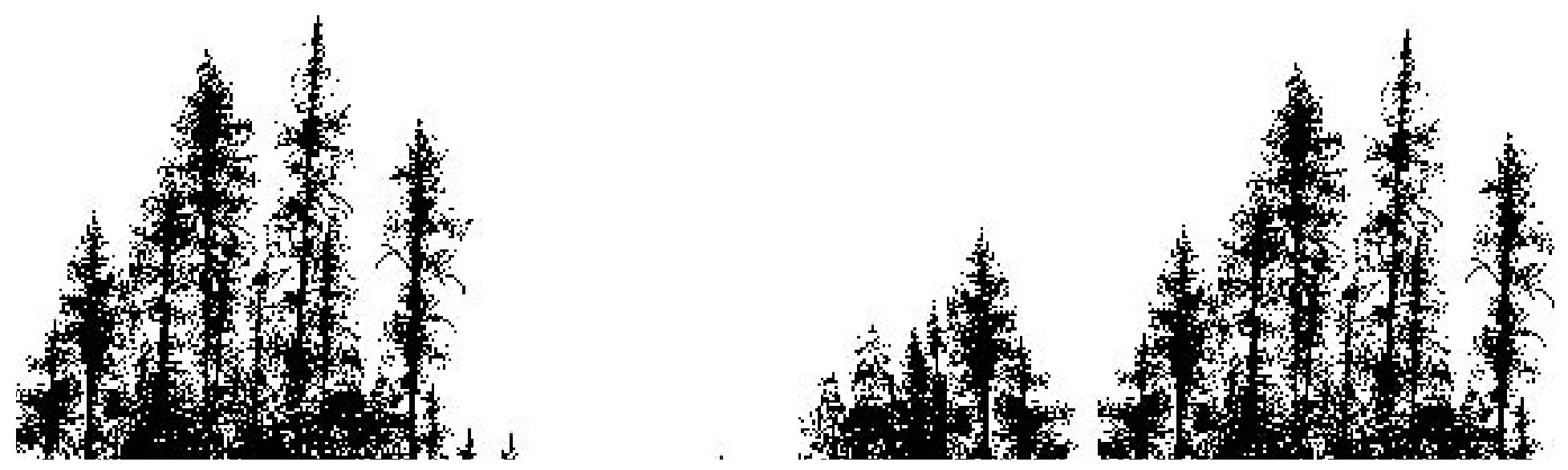


\section{RADIOACTIVITY CONCERNS OF URANIUM AND THORIUM DEPOSITS AT BOKAN MOUNTAIN, SOUTHEASTERN ALASKA}

Naturally occurring uranium and thorium mineral deposits are of environmental significance because they produce radon and radium through radioactive decay. The associated radioactivity is a health concern because excessive exposure to radioactivity can produce cancer in humans. A few small uranium deposits are scattered throughout Alaska, but the only uranium mine (RossAdams) is on Bokan Mountain at the south end of Prince of Wales Island about $60 \mathrm{~km}$ southwest of the town of Ketchikan (fig. 25). Uranium and thorium are most widely used in the nuclear power industry and for nuclear weapons, but current social and political issues have depressed the prices and demand for uranium. For these reasons, many uranium mines, including the Ross-Adams, are presently closed, and uranium deposits in Alaska are not currently under study. However, because of the health concerns associated with radioactivity, potential hazards of deposits like those on Bokan Mountain are summarized here.

Uranium deposits on Bokan Mountain.-In 1955, prospectors found radioactive uranium- and thorium-bearing quartz-rich veins in granite over a $30 \mathrm{~km}^{2}$ area on Bokan Mountain (fig. 26) (Roppel, 1991). These veins are highly radioactive and widespread in this area, but most of the veins are small, generally $2 \mathrm{~cm}$ or less in width. Primary radioactive minerals in the prospects include uraninite, thorianite, and uranothorite. Some of the veins at Bokan Mountain exceed 10 percent thorium ore $\left(\mathrm{ThO}_{2}\right)$ and 1 percent uranium ore $\left(\mathrm{U}_{3} \mathrm{O}_{8}\right)$, which are considered high concentrations (Thompson, 1988). Although several of the veins have been prospected, only the Ross-Adams deposit has been mined (fig. 27). Initially at Ross-Adams, a $110 \mathrm{~m}$ long, $15 \mathrm{~m}$ wide, and $10 \mathrm{~m}$ deep open pit was developed (MacKevett, 1963), but later underground workings were driven along a $110 \mathrm{~m}$ long pipe. The deposit was mined intermittently from 1957 to 1971 until the ore was exhausted. Altogether, about $85,000 \mathrm{t}$ of high-grade uranium ore averaging about 1 percent $\mathrm{U}_{3} \mathrm{O}_{8}$ was produced (Staatz, 1978). The Ross-Adams open pit still contains some stockpiles of radioactive rock.
Human hazards of radioactive deposits. - In certain conditions, radioactivity associated with uranium and thorium deposits can be of environmental concern. The major health concerns for humans are long-term exposure to:

- Radon in confined air spaces. Radon concentrations could be high near any radioactive deposit.

- Uranium, radium, and radon in drinking water. Uranium is easily oxidized by air and water, and oxidized uranium compounds, as well as by-products radium and radon, are soluble in water. Thorium in water is generally of lesser concern because it occurs in low concentrations in most surface waters, and thorium minerals do not dissolve easily in water.

- Surface radiation and inhalation or ingestion of radioactive dust.

In all these cases, long-term exposure to radioactivity must be considered unlikely because the mines on Bokan Mountain are closed and the area is so remote. For example, surface and ground waters near the Bokan deposits could have high concentrations of dissolved uranium, radium, and radon, but the area is distant from any major water supply.

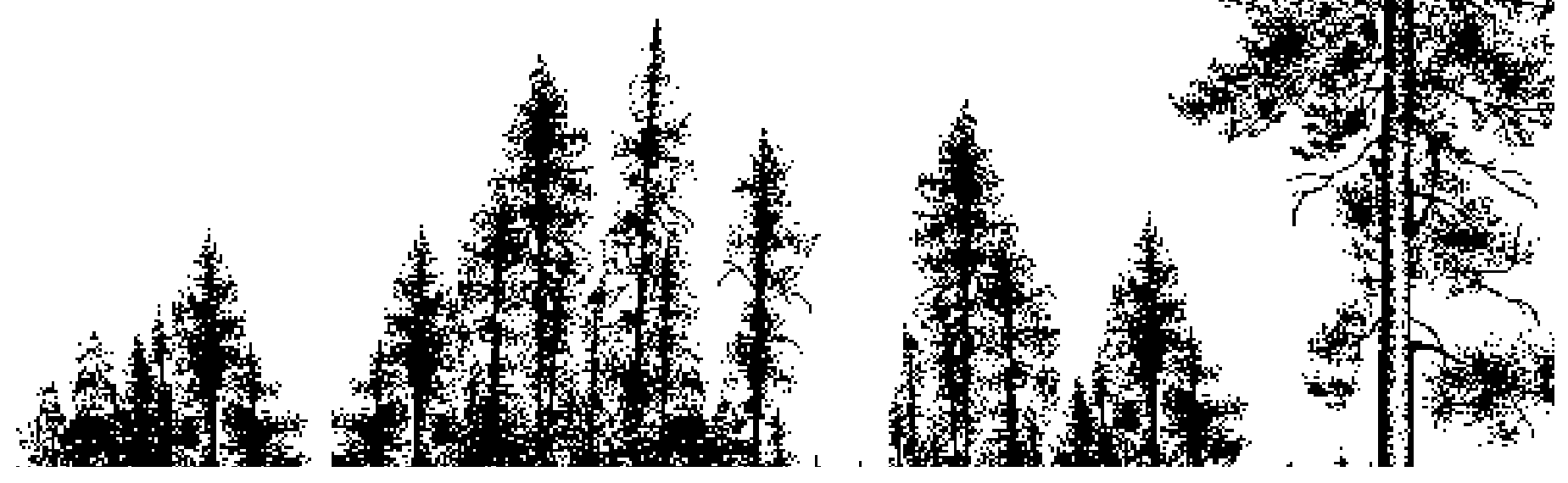




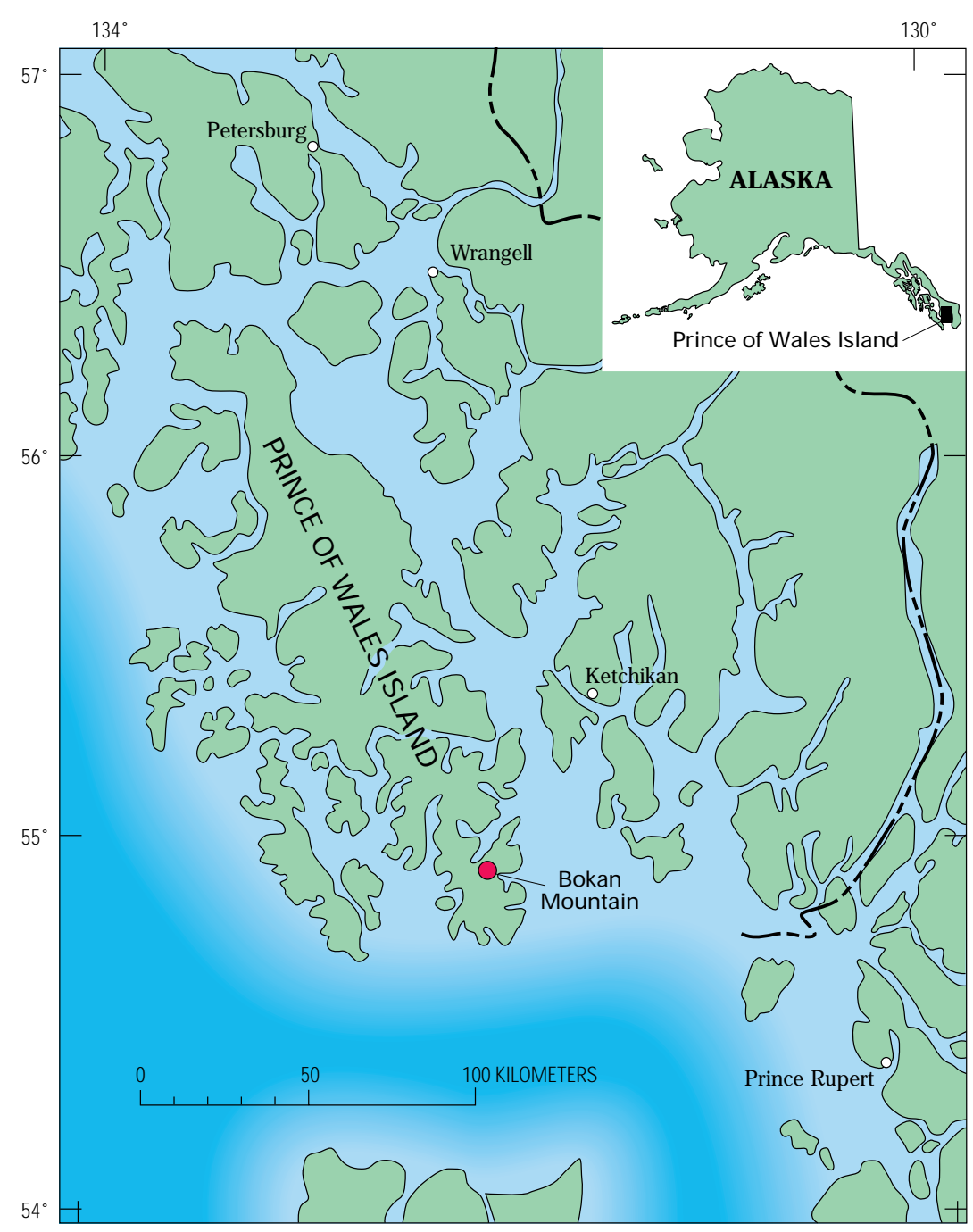

Figure 25. Location of Bokan Mountain uranium deposits. 


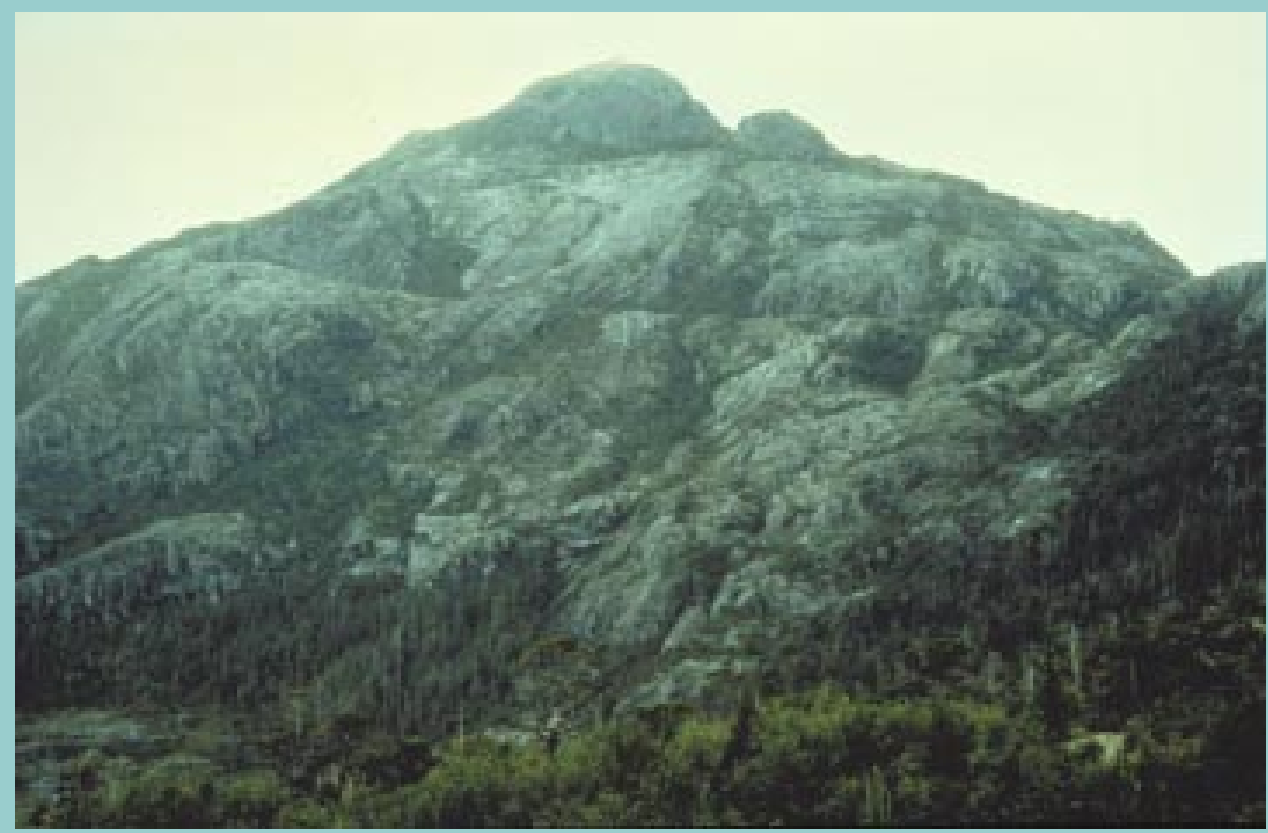

Figure 26. View of the granitic intrusion (center) at Bokan Mountain.

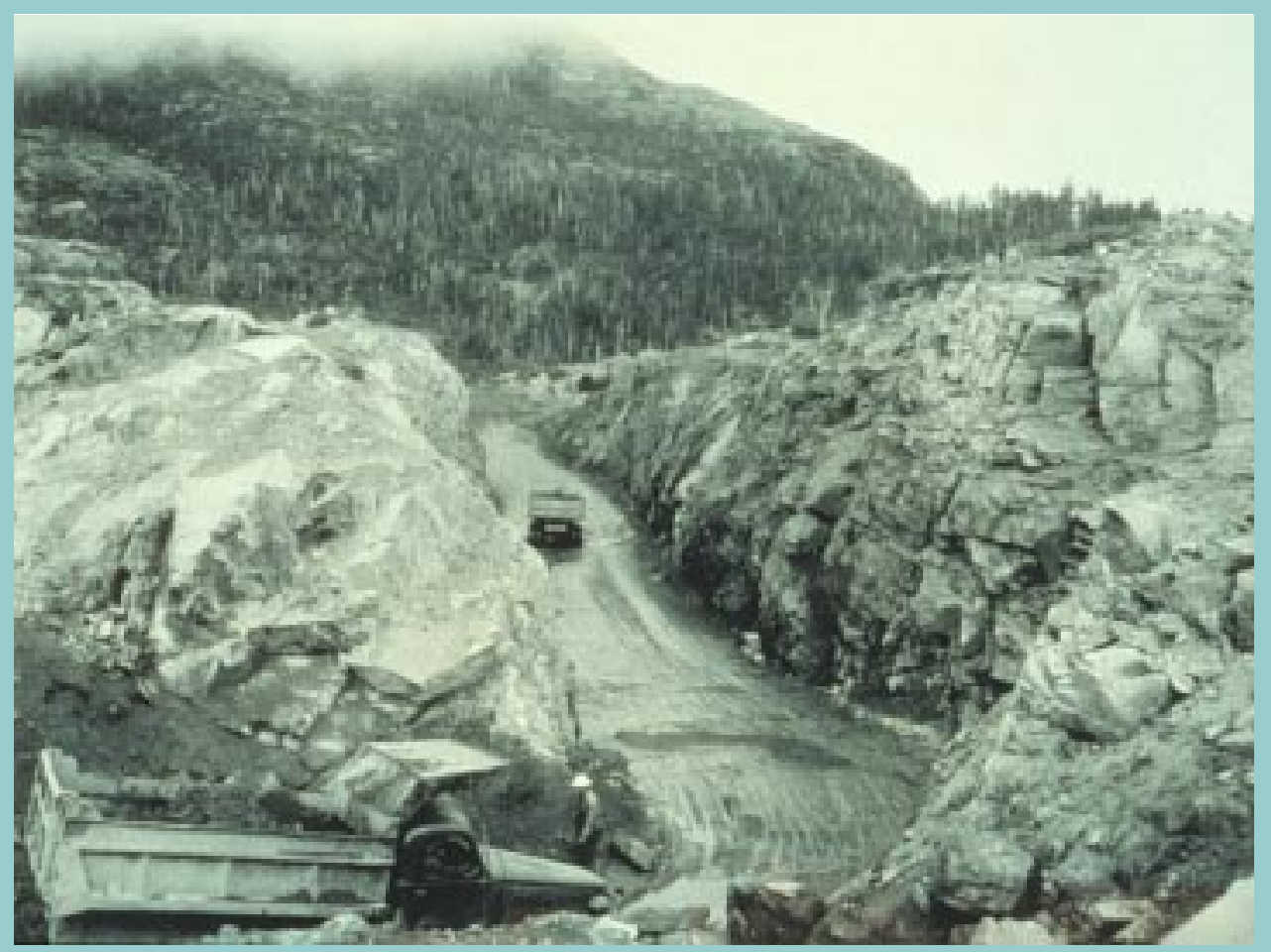

Figure 27. Photograph from the 1960's showing mining of uranium ore at the Ross-Adams mine. 


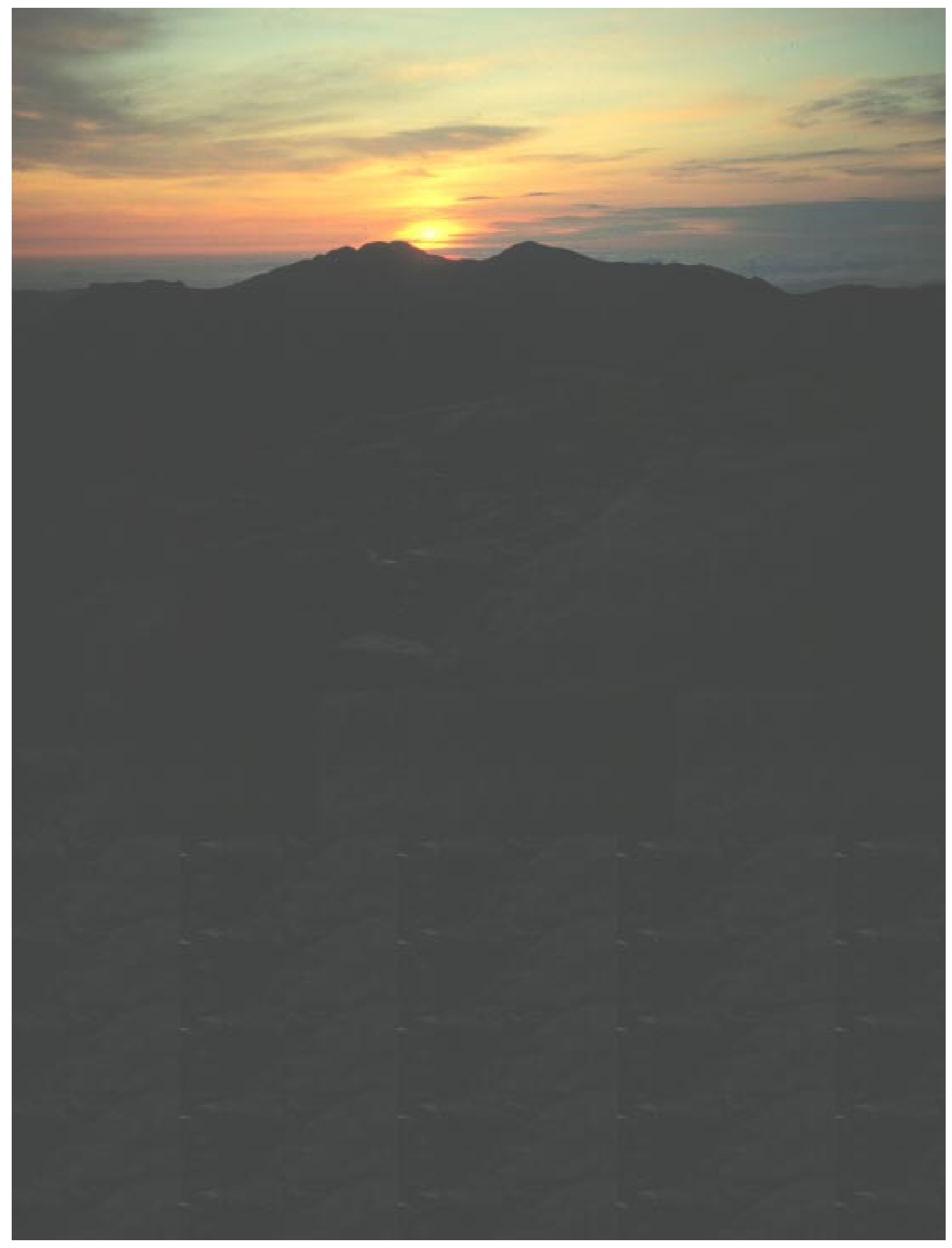




\section{SUMMARY}

The studies of Alaskan mineral deposits presented herein show that various types of mineral deposits have very different geochemical characteristics that influence the chemistry of waters draining the mineral deposits. These characteristics are directly related to the mineralogy, geochemistry, and geology of each mineral deposit. For some deposits, downstream water geochemistry may present environmental problems for the local ecosystems. For example, the most adverse effects were observed downstream from the massive sulfide deposits in the northwestern Brooks Range and in Prince William Sound, where water samples contain the highest concentrations of metals and lowest $\mathrm{pH}$ values of the deposits studied here (fig. 28). Such acid- and metal-rich waters result from the weathering of pyrite and other base-metal sulfide minerals in these deposits that form acid and release heavy metals during the process. Water samples collected near the massive sulfide deposits may contain heavy metal concentrations in excess of State and Federal water standards (table 2). Although waters emanating from these deposits are high in acid and metal content, these waters are rapidly diluted downstream, usually within a few kilometers below the deposits (for example, deposits in the Brooks Range).

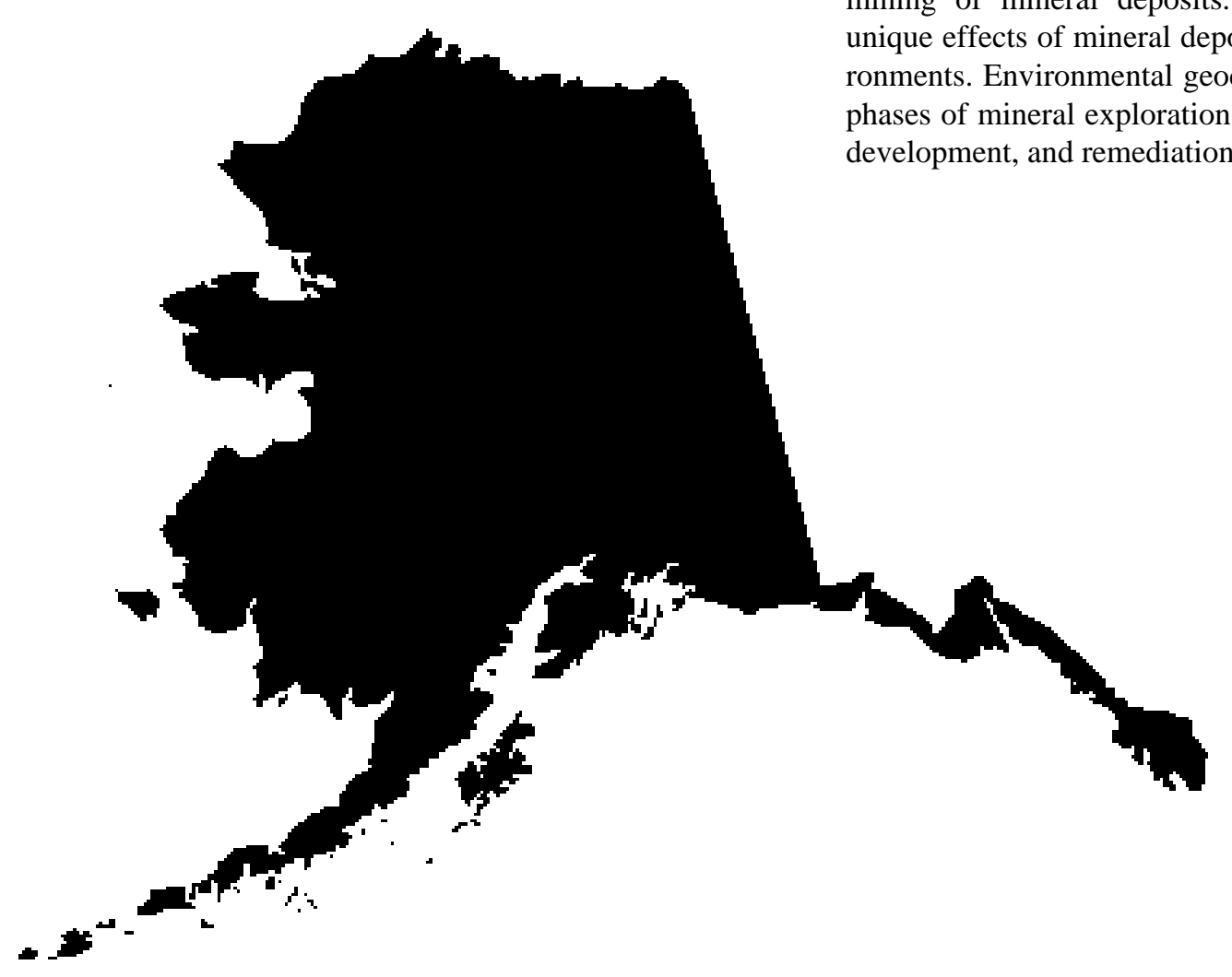

Most of the other Alaskan deposits studied contain low acid and metal concentrations in water collected downstream from the deposits (fig. 28). For example, stream waters collected downstream from mercury deposits in southwestern Alaska have near-neutral $\mathrm{pH}$ values and contain low mercury contents, suggesting that these deposits produce only minor amounts of acid and heavy metals upon weathering. The low dissolved mercury concentration is due to the presence of cinnabar, which is resistant to physical and chemical weathering and does not easily form acid water. A greater environmental problem of the mercury deposits is the elevated mercury concentrations in stream sediment samples and fish that were collected downstream from the mines and deposits; however, the mercury concentrations in the fish are below the recommended FDA level for mercury in edible fish, suggesting only minor effects on local food chains. Alaskan gold veins and gold placer deposits contain pyrite and other sulfide minerals capable of producing acid water, but the amount of these sulfide minerals is generally small. Thus, weathering of such deposits does not produce water with significant concentrations of acid or heavy metals. Similarly, the chromium-bearing deposits contain little or no pyrite, and waters draining these deposits contain low-metal concentrations and have near-neutral $\mathrm{pH}$ values.

The case studies presented herein summarize the environmental effects of several types of mineral deposits. The results emphasize the need for additional, well-designed geochemical studies, which are necessary for the classification and understanding of any mineral deposit, but which will also address potential environmental concerns. Environmental geochemical studies are now a common practice in the mining industry, before, during, and subsequent to the mining of mineral deposits. These studies help predict unique effects of mineral deposits on the surrounding environments. Environmental geochemistry can be useful in all phases of mineral exploration, as well as in mine planning, development, and remediation. 


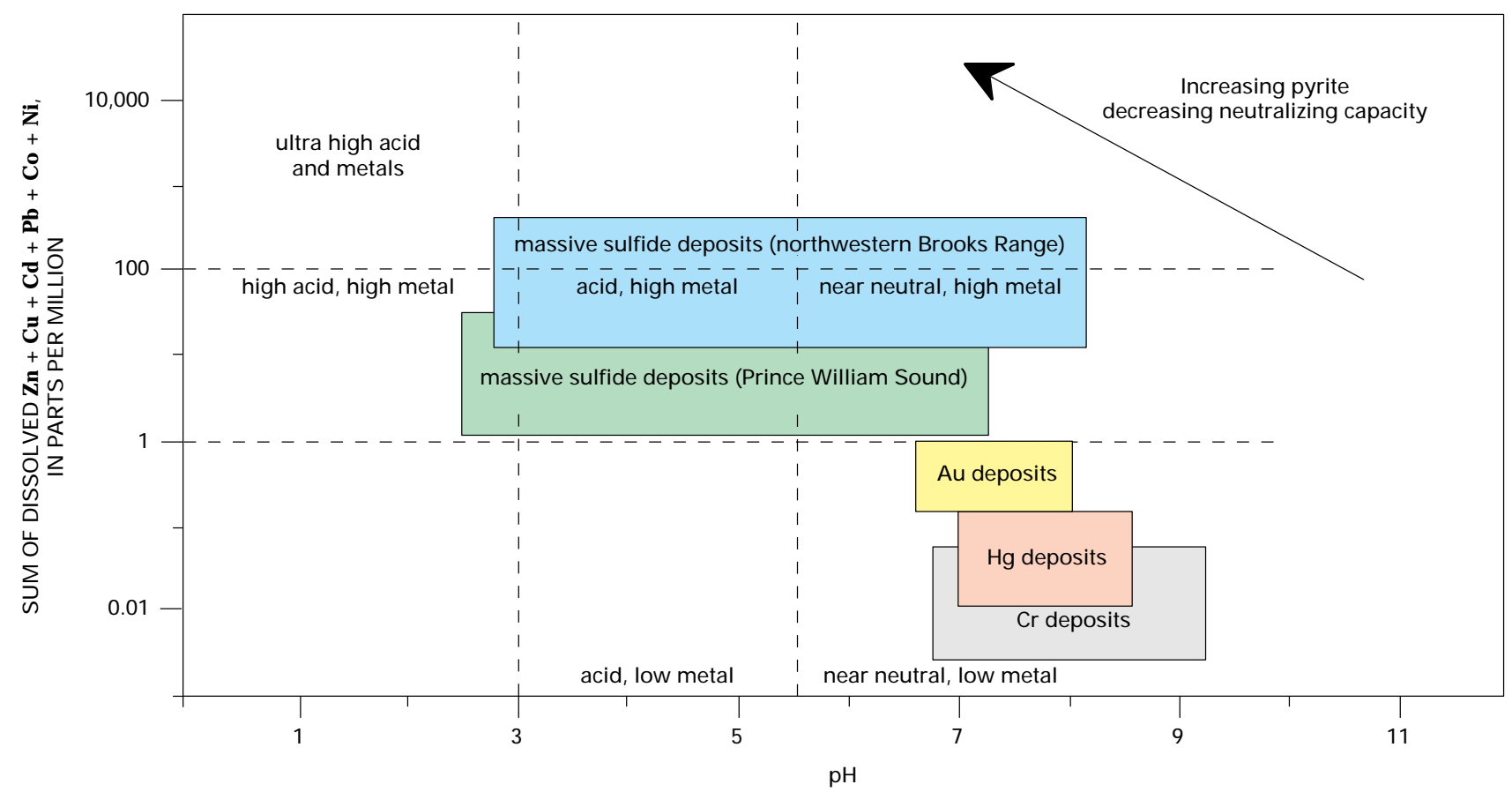

Figure 28. Plot of dissolved metal concentrations in water versus water $\mathrm{pH}$ for several Alaskan deposit types. This plot shows that the waters emanating from Alaskan mercury, gold, and chromium deposits have near-neutral $\mathrm{pH}$ and low dissolved metal contents, whereas Alaskan massive sulfide deposits form waters that are often high in acid and metal contents.

Table 2. Geochemical data summary of mineral deposits studied.

\begin{tabular}{lccc}
\hline Deposit type & $\begin{array}{c}\text { Elements of } \\
\text { environmental concern }\end{array}$ & $\begin{array}{c}\text { Element concentrations in water } \\
\text { exceeding EPA-CMC standards }\end{array}$ & $\begin{array}{c}\mathrm{pH} \text { range in } \\
\text { stream water }\end{array}$
\end{tabular}

\begin{tabular}{lllr}
\hline $\begin{array}{l}\text { Massive sulfides } \\
\text { (sedimentary rock } \\
\text { hosted) }\end{array}$ & $\mathrm{Pb}, \mathrm{Zn}, \mathrm{Cd}, \mathrm{Cu}$ & $\begin{array}{c}2,250 \mathrm{ppb} \mathrm{Pb}, 272,000 \mathrm{ppb} \mathrm{Zn,} \\
800 \mathrm{ppb} \mathrm{Cd}, 360 \mathrm{ppb} \mathrm{Cu}\end{array}$ & $2.8-8.1$ \\
$\begin{array}{l}\text { Massive sulfides } \\
\text { (volcanic rock } \\
\text { hosted) }\end{array}$ & $\mathrm{Cu}, \mathrm{Pb}, \mathrm{Zn}, \mathrm{Cd}$ & $\begin{array}{c}3,600 \mathrm{ppb} \mathrm{Cu}, 3,300 \mathrm{ppb} \mathrm{Zn}, \\
220 \mathrm{ppb} \mathrm{Pb}, 27 \mathrm{ppb} \mathrm{Cd}\end{array}$ & $2.6-7.3$ \\
& & & \\
Gold veins & $\mathrm{As}, \mathrm{Pb}, \mathrm{Zn}, \mathrm{Cd}, \mathrm{Sb}$ & $6.4-8.0$ \\
$\begin{array}{l}\text { Gold placers } \\
\text { Mercury }\end{array}$ & $\mathrm{As}, \mathrm{Pb}, \mathrm{Zn}, \mathrm{Cd}, \mathrm{Hg}$ & $6.5-8.1$ \\
Chromium & $\mathrm{Hg}, \mathrm{Sb}, \mathrm{As}$ & $7.0-8.4$ \\
& $\mathrm{Cr}$ & $6.7-9.3$
\end{tabular}

${ }^{1} \mathrm{CMC}$ is the Environmental Protection Agency's water quality criteria to protect against acute effects in aquatic life and is the highest instream concentration of a toxic pollutant consisting of a 1-hour average not to be exceeded more than once every 3 years on the average. 


\section{REFERENCES CITED}

For more information on the silver-lead-zinc mineral deposits in the northwestern Brooks Range see:

Dames and Moore, 1983, Environmental baseline studies, Red Dog Project: Prepared for Cominco Alaska, Inc., Anchorage, AK.

Kelley, K.D., 1995, Natural environmental effects of silver-leadzinc deposits in the Brooks Range, Alaska: U.S. Geological Survey Fact Sheet 092-95.

Kelley, K.D., and Taylor, C.D., 1996, Natural environmental effects associated with the Drenchwater zinc-lead-silver massive sulfide deposit, west-central Brooks Range with comparisons to the Lik and Red Dog deposits, in Moore, T.E., and Dumoulin, J.A., eds., Geologic studies in Alaska by the U.S. Geological Survey, 1994: U.S. Geological Survey Bulletin 2152, p. 31-46.

Runnels, D.D., Shepherd, T.A., and Angino, E.E., 1992, Metals in water-Determining natural background concentrations in mineralized areas: Environmental Science and Technology, v. 26, p. 2316-2323.

For more information on massive sulfide deposits in Prince William Sound please refer to:

Goldfarb, R.J., Nelson, S.W., Taylor, C.D., d'Angelo, W.M., and Meier, A.L., 1996, Acid-mine drainage associated with volcanogenic massive sulfide deposits, Prince William Sound, Alaska, in Moore, T.E., and Dumoulin, J.A., eds., Geologic studies in Alaska by the U.S. Geological Survey, 1994: U.S. Geological Survey Bulletin 2152, p. 3-16.

For more information on mercury in southwestern Alaska please refer to:

Gray, J.E., 1994, Environmental geochemistry of mercury mines in Alaska: U.S. Geological Survey Fact Sheet 94-072.

Gray, J.E., Meier, A.L., O'Leary, R.M., Outwater, C., and Theodorakos, P.M., 1996, Environmental geochemistry of mercury deposits in southwestern Alaska-Mercury contents in fish, stream-sediment, and stream-water samples, in Moore, T.E., and Dumoulin, J.A., eds., Geologic studies in Alaska by the U.S. Geological Survey, 1994: U.S. Geological Survey Bulletin 2152, p. 17-30.

Gray, J.E., Theodorakos, P.M., Budahn, J.R., and O'Leary, R.M., 1994, Mercury in the environment and its implications, Kuskokwim River Region, southwestern Alaska, in Till, A.B., and Moore, T.E., eds., Geologic studies in Alaska by the U.S. Geological Survey, 1993: U.S. Geological Survey Bulletin 2107, p. 3-13.
For more information on southern Alaska gold vein deposits please refer to:

Carrick, S., and Maurer, M., 1994, Preliminary water resource assessment of the Girdwood area, Alaska: Division of Geological and Geophysical Surveys Public-Data File 94-51, 36 p.

Cieutat, B.A., Goldfarb, R.J., Borden, J.C., McHugh, J.B., and Taylor, C.D., 1994, Environmental geochemistry of mesothermal gold deposits, Kenai Fjords National Park, south-central Alaska, in Till, A.B., and Moore, T.E., eds., Geologic studies in Alaska by the U.S. Geological Survey, 1993: U.S. Geological Survey Bulletin 2107, p. 21-26.

Trainor, T.P., Fleisher, S., Wildeman, T.R., Goldfarb, R.J., and Huber, C., 1996, Environmental geochemistry of the McKinley Lake gold mining district, Chugach National Forest, Alaska, in Moore, T.E., and Dumoulin, J.A., eds., Geologic studies in Alaska by the U.S. Geological Survey, 1994: U.S. Geological Survey Bulletin 2152, p. 47-58.

For more information on Alaskan placer deposits please refer to:

Ray, S.R., Vohden, J., and Morgan, W., 1992, Investigation of trace metals related to placer mining on Fairbanks and Porcupine Creeks: Alaskan Division of Geological and Geophysical Surveys, Public-Data File 92-13, 27 p.

Swainbank, R.C., Bundtzen, T.K., Clough, A.H., Henning, M.W., and Hanson, E.W., 1995, Alaska's Mineral Industry, 1994: Division of Geological and Geophysical Surveys, Special Report 49, 77 p.

U.S. Minerals Management Service, 1989, Mercury in the marine environment, workshop proceedings: OCS MMS 89-0049. 
For more information on chromium studies please refer to:

Barnes, Ivan, and O'Neil, J.R., 1969, The relationship between fluids in some fresh alpine-type ultramafics and possible modern serpentinization, western United States: Geological Society of America Bulletin, v. 80, p. 1947-1960.

Hem, J.D., 1992, Study and interpretation of the chemical characteristics of natural water: U.S. Geological Survey WaterSupply Paper 2254, $263 \mathrm{p}$.

Simon, N.S., Demas, C., and d'Angelo, W., 1994, Geochemistry and solid-phase association of chromium in sediment from the Calcasieu River and estuary, Louisiana, U.S.A.: Chemical Geology, v. 116, p. 123-135.
For more information on the mineral deposit at Bokan Mountain please refer to:

MacKevett, E.M., Jr., 1963, Geology and ore deposits of the Bokan Mountain uranium-thorium area, southeastern Alaska: U.S. Geological Survey Bulletin 1154, 125 p.

Roppel, Patricia, 1991, Fortunes from the Earth-An history of the base and industrial minerals of southeast Alaska: Manhattan, Kans., Sunflower University Press, 139 p.

Staatz, M.H., 1978, I and L uranium and thorium vein system, Bokan Mountain, southeastern Alaska: Economic Geology, v. 73 , p. $512-523$.

Thompson, T.B., 1988, Geology and uranium-thorium mineral deposits of the Bokan Mountain Granite Complex, southeastern Alaska: Ore Geology Reviews, v. 3, p. 193-210.

For information on water standards please refer to:

Alaska Department of Environmental Conservation, 1994, Drinking water regulations: State of Alaska, Department of Environmental Conservation report 18-ACC-80, 195 p.

Environmental Protection Agency, 1992, Water quality standards; establishment of numeric criteria for priority toxic pollutants; States' compliance; final rule: Federal Register, 40 CFR Part 131 , v. 57, no. 246, p. 60847-60916.

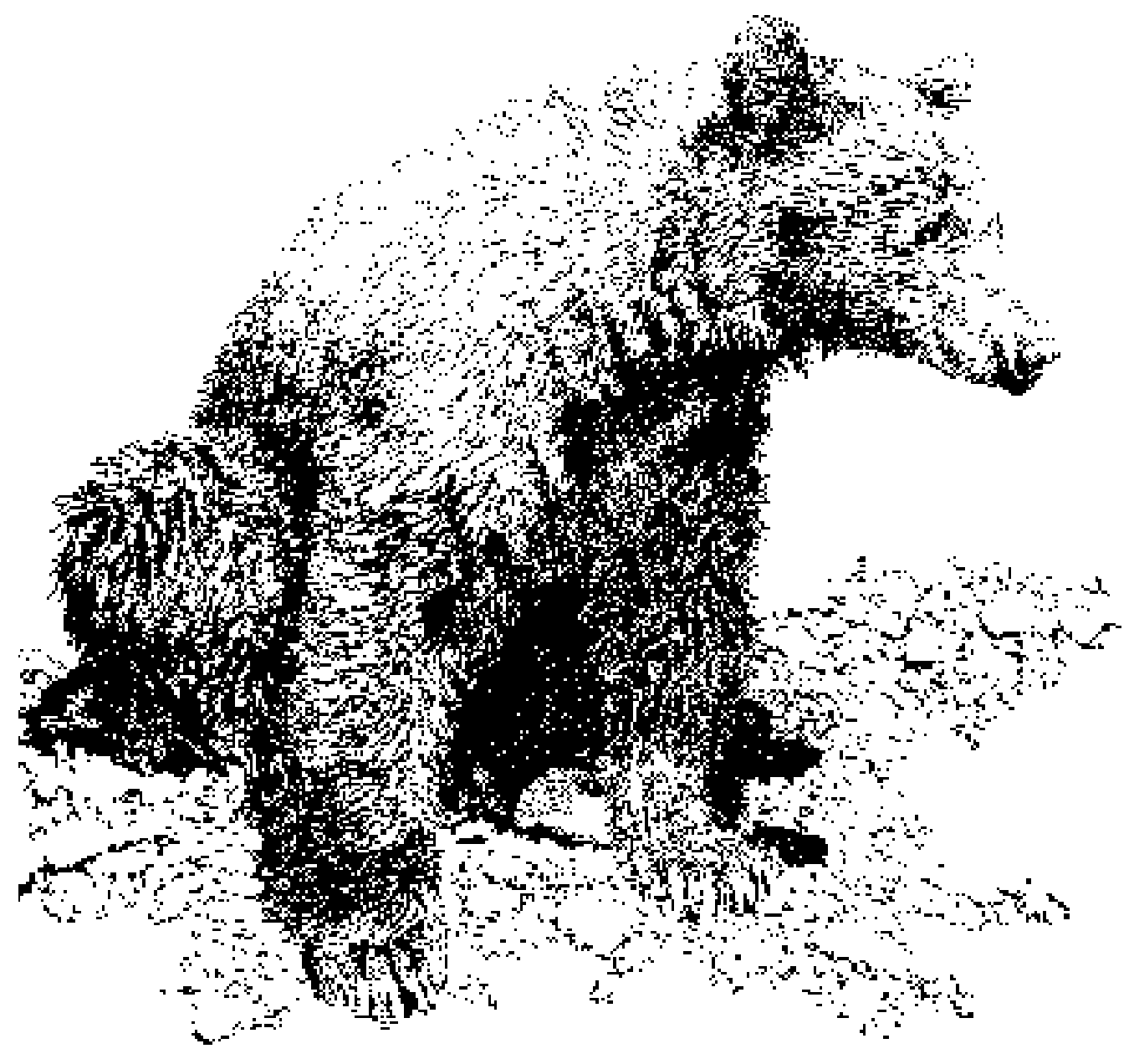




\section{GLOSSARY}

amalgamation of gold. A process used for the separation of gold. Gold, especially fine grained gold, can be recovered using liquid mercury, which has the ability to blend or stick to gold, thereby effectively extracting gold particles from stream-sediment samples. Amalgamation of gold was widely used in the early 1900's for gold extraction in many gold deposits, especially placer deposits.

acid drainage. The formation of acid water principally by surface oxidation of rocks containing sulfide minerals, such as pyrite (iron sulfide). When surface water comes in contact with the sulfide minerals, sulfuric acid is produced, which further dissolves surrounding rocks and minerals. Metals are often more soluble in acid solutions, and thus, acid drainage generally carries high concentrations of dissolved metals. Such acid waters found downstream from mines are called acid-mine drainage.

arsenopyrite. Iron-arsenic sulfide (FeAsS), steel gray to silver white in color, common in vein gold deposits and in some massive sulfide deposits.

background concentrations. In geochemistry, this refers to chemical concentrations in natural materials that have not been influenced by the activities of humans. In studies of mineral deposits, background samples are those collected from unmineralized areas, generally upstream from mines or distant from mineralized areas. Thus, geochemical backgrounds represent concentrations that are considered "normal or usual" and are unaffected by mineral deposits or mining.

bioaccumulation. Increase of metal concentrations in organisms through uptake from water or food sources.

biomagnification. Increasing element concentrations with ascending position in the food chain. chalcopyrite. Copper-iron sulfide $\left(\mathrm{FeCuS}_{2}\right)$, brass yellow in color, is common in a variety of mineral deposits and is an important ore of copper.

chromite. Iron-chromium oxide $\left(\mathrm{FeCr}_{2} \mathrm{O}_{4}\right)$ is a hard, heavy mineral, typically black or dark brown. Chromite is found in mafic and ultramafic rocks and is a common ore of chromium.

cinnabar. Mercury sulfide $(\mathrm{HgS})$ is most commonly a brilliant red color. Cinnabar contains 86 percent mercury and is an important ore of mercury.

ecosystem. An area consisting of the physical environment and its living elements (such as plants and animals) and nonliving elements (such as water, rocks, and soils) that might affect this area.

galena. Lead sulfide $(\mathrm{PbS})$ that commonly contains significant amounts of silver. Galena is usually silver gray to blue gray in color, forms cubes, and is common in many vein and massive sulfide deposits. Galena is an important ore of lead and silver.

heavy metals. These are among the most toxic of the metals. Copper, lead, zinc, cadmium, mercury, and iron are common heavy metals, and such metals have high atomic weights, and therefore are commonly called "heavy metals." These metals have a high affinity for sulfur and often form sulfur compounds, and because sulfur is easily oxidized by air and water, these metals can be transported in water downstream from mineral deposits that contain them.

marcasite. An iron sulfide $\left(\mathrm{FeS}_{2}\right)$ mineral, commonly light gray to brassy in color, that has a radiating fibrous form, is dimorphous with pyrite, and often resembles pyrite in appearance; but marcasite has a lower specific gravity. Marcasite is common in sedimentary rocks and some ore deposits. 
pH. A measure of the amount of acid or base in a solution, $\mathrm{pH}$ is related to the concentration of the hydrogen ions. Neutral solutions have a $\mathrm{pH}$ of 7 , whereas the $\mathrm{pH}$ of acid solutions is less than 7 and alkaline solutions have $\mathrm{pH}$ values greater than 7 . Acids generally have an excess of hydrogen ions $\left(\mathrm{H}^{+}\right)$and bases have an excess of hydroxyl ions $(\mathrm{OH}-)$. Sulfuric acid $\left(\mathrm{H}_{2} \mathrm{SO}_{4}\right)$ is an example of a strong acid, and sodium hydroxide $(\mathrm{NaOH})$, a type of lye, is a strong base.

ppb. Abbreviation for parts per billion. This is a concentration measured as micrograms per liter or as micrograms per kilogram.

ppm. Abbreviation for parts per million. This is a concentration measured as milligrams per liter or as milligrams per kilogram.

pyrite. Iron sulfide $\left(\mathrm{FeS}_{2}\right)$ is one of the most widespread sulfide minerals and is common in metallic mineral deposits. Pyrite is typically cubic in form and palebronze or brass-yellow in color; it is often called "fools gold." The primary concern of pyrite in mineral deposits is its tendency to form strong acid (sulfuric acid) upon oxidation.

pyrrhotite. An iron sulfide mineral, generally bronze to redbrown in color, commonly massive and not often found as crystals. Pyrrhotite is common in massive sulfide deposits and may contain significant amounts of nickel; it is therefore a source of nickel in some deposits.

sphalerite. Zinc-iron sulfide $((\mathrm{ZnFe}) \mathrm{S})$, yellow, brown, or black in color. Sphalerite often contains minor amounts of cadmium, arsenic, and manganese, and is a widespread zinc ore.

stibnite. Antimony sulfide $\left(\mathrm{Sb}_{2} \mathrm{~S}_{3}\right)$, silver-gray sulfide mineral with a bright metallic luster that commonly forms bladed crystals containing striations. Stibnite is the principal ore of antimony and often contains some silver and gold.

sulfide minerals. Minerals containing the reduced form of sulfur $\left(\mathrm{S}^{2-}\right)$, which is bound with common metals, such as iron in pyrite $\left(\mathrm{FeS}_{2}\right)$, lead in galena $(\mathrm{PbS})$, zinc in sphalerite $(\mathrm{ZnS})$, mercury in cinnabar $(\mathrm{HgS})$, among others. Sulfide minerals are common in many types of metallic mineral deposits. Many of these minerals can be of environmental concern because they can produce acid during oxidation. When acid is formed, it can dissolve metals in surrounding minerals and rocks, releasing them into surface waters of streams and rivers. thorianite. Thorium oxide $\left(\mathrm{ThO}_{2}\right)$, a thorium ore, generally cubic in form and highly radioactive, containing impurities or rare earth elements such as cerium.

ultramafic rock. A rock composed primarily of minerals such as pyroxene and olivine. Ultramafic rocks are typically of igneous origin, dark in color, and consist of peridotite, pyroxenite, and dunite rock types.

uraninite. Uranium oxide $\left(\mathrm{UO}_{2}\right)$, commonly called pitchblende, is black, brown or steel gray in color, and commonly contains thorium, radium, cerium, and lead impurities. Uraninite is highly radioactive, easily oxidized, and common in vein mineral deposits in granites.

uranothorite. Thorium-uranium silicate ((Th, U)SiO $\left.{ }_{4}\right)$, highly radioactive, typically brown, or black, and is an ore of uranium and thorium found most commonly in vein deposits in granites.

Manuscript approved for publication February 28, 1996

Published in the Central Region, Denver, Colorado

Graphics by Richard P. Walker, Barbara Ramsey, and Carol A. Quesenberry

Photocomposition and design by Carol A. Quesenberry

Edited by Lorna Carter and Carole A. Bales

Online composition by Joan G. Nadeau 


\section{AVAILABILITY OF BOOKS AND MAPS OF THE U.S. GEOLOGICAL SURVEY}

Instructions on ordering publications of the U.S. Geological Survey, along with prices of the last offerings, are given in the current-year issues of the monthly catalog "New Publications of the U.S. Geological Survey." Prices of available U.S. Geological Survey publications released prior to the current year are listed in the most recent annual "Price and Availability List." Publications that may be listed in various U.S. Geological Survey catalogs (see back inside cover) but not listed in the most recent annual "Price and Availability List" may no longer be available.

Reports released through the NTIS may be obtained by writing to the National Technical Information Service, U.S. Department of Commerce, Springfield, VA 22161; please include NTIS report number with inquiry.

Order U.S. Geological Survey publications by mail or over the counter from the offices listed below.

\section{BY MAIL}

\section{Books}

Professional Papers, Bulletins, Water-Supply Papers, Techniques of Water-Resources Investigations, Circulars, publications of general interest (such as leaflets, pamphlets, booklets), single copies of Earthquakes \& Volcanoes, Preliminary Determination of Epicenters, and some miscellaneous reports, including some of the foregoing series that have gone out of print at the Superintendent of Documents, are obtainable by mail from

\section{U.S. Geological Survey, Information Services Box 25286, Federal Center Denver, CO 80225}

Subscriptions to periodicals (Earthquakes \& Volcanoes and Preliminary Determination of Epicenters) can be obtained ONLY from the

\section{Superintendent of Documents Government Printing Office Washington, DC 20402}

(Check or money order must be payable to Superintendent of Documents.)

\section{Maps}

For maps, address mail orders to

\section{U.S. Geological Survey, Information Services Box 25286, Federal Center$$
\text { Denver, CO } 80225
$$

Residents of Alaska may order maps from

\section{U.S. Geological Survey, Earth Science Information Center 101 Twelfth Ave., Box 12 Fairbanks, AK 99701}

\section{OVER THE COUNTER}

\section{Books and Maps}

Books and maps of the U.S. Geological Survey are available over the counter at the following U.S. Geological Survey offices, all of which are authorized agents of the Superintendent of Documents.

- ANCHORAGE, Alaska-Rm. 101, 4230 University Dr.

- LAKEWOOD, Colorado-Federal Center, Bldg. 810

- MENLO PARK, California-Bldg. 3, Rm. 3128, 345 Middlefield Rd.

- RESTON, Virginia-USGS National Center, Rm. 1C402, 12201 Sunrise Valley Dr.

- SALT LAKE CITY, Utah-Federal Bldg., Rm. 8105, 125 South State St.

- SPOKANE, Washington-U.S. Post Office Bldg., Rm. 135, West 904 Riverside Ave.

- WASHINGTON, D.C.-Main Interior Bldg., Rm. 2650, 18th and C Sts., NW.

\section{Maps Only}

Maps may be purchased over the counter at the following U.S. Geological Survey offices:

- FAIRBANKS, Alaska-New Federal Bldg, 101 Twelfth Ave.

- ROLLA, Missouri-1400 Independence Rd.

- STENNIS SPACE CENTER, Mississippi-Bldg. 3101 


\section{SELECTED SERIES OF U.S. GEOLOGICAL SURVEY PUBLICATIONS}

\section{Periodicals}

Earthquakes \& Volcanoes (issued bimonthly).

Preliminary Determination of Epicenters (issued monthly).

\section{Technical Books and Reports}

Professional Papers are mainly comprehensive scientific reports of wide and lasting interest and importance to professional scientists and engineers. Included are reports on the results of resource studies and of topographic, hydrologic, and geologic investigations. They also include collections of related papers addressing different aspects of a single scientific topic.

Bulletins contain significant data and interpretations that are of lasting scientific interest but are generally more limited in scope or geographic coverage than Professional Papers. They include the results of resource studies and of geologic and topographic investigations; as well as collections of short papers related to a specific topic.

Water-Supply Papers are comprehensive reports that present significant interpretive results of hydrologic investigations of wide interest to professional geologists, hydrologists, and engineers. The series covers investigations in all phases of hydrology, including hydrology, availability of water, quality of water, and use of water.

Circulars present administrative information or important scientific information of wide popular interest in a format designed for distribution at no cost to the public. Information is usually of short-term interest.

Water-Resources Investigations Reports are papers of an interpretive nature made available to the public outside the formal USGS publications series. Copies are reproduced on request unlike formal USGS publications, and they are also available for public inspection at depositories indicated in USGS catalogs.

Open-File Reports include unpublished manuscript reports, maps, and other material that are made available for public consultation at depositories. They are a nonpermanent form of publication that may be cited in other publications as sources of information.

\section{Maps}

Geologic Quadrangle Maps are multicolor geologic maps on topographic bases in 7 1/2- or 15-minute quadrangle formats (scales mainly $1: 24,000$ or $1: 62,500$ ) showing bedrock, surficial, or engineering geology. Maps generally include brief texts; some maps include structure and columnar sections only.

Geophysical Investigations Maps are on topographic or planimetric bases at various scales, they show results of surveys using geophysical techniques, such as gravity, magnetic, seismic, or radioactivity, which reflect subsurface structures that are of economic or geologic significance. Many maps include correlations with the geology.

Miscellaneous Investigations Series Maps are on planimetric or topographic bases of regular and irregular areas at various scales; they present a wide variety of format and subject matter. The series also includes 7 1/2-minute quadrangle photogeologic maps on planimetric bases which show geology as interpreted from aerial photographs. The series also includes maps of Mars and the Moon.
Coal Investigations Maps are geologic maps on topographic or planimetric bases at various scales showing bedrock or surficial geology, stratigraphy, and structural relations in certain coal-resource areas.

Oil and Gas Investigations Charts show stratigraphic information for certain oil and gas fields and other areas having petroleum potential.

Miscellaneous Field Studies Maps are multicolor or black-andwhite maps on topographic or planimetric bases on quadrangle or irregular areas at various scales. Pre-1971 maps show bedrock geology in relation to specific mining or mineral-deposit problems; post-1971 maps are primarily black-and-white maps on various subjects such as environmental studies or wilderness mineral investigations.

Hydrologic Investigations Atlases are multicolored or black-andwhite maps on topographic or planimetric bases presenting a wide range of geohydrologic data of both regular and irregular areas; the principal scale is $1: 24,000$, and regional studies are at 1:250,000 scale or smaller.

\section{Catalogs}

Permanent catalogs, as well as some others, giving comprehensive listings of U.S. Geological Survey publications are available under the conditions indicated below from USGS Map Distribution, Box 25286, Building 810, Denver Federal Center, Denver, CO 80225. (See latest Price and Availability List.)

"Publications of the Geological Survey, 1879-1961" may be purchased by mail and over the counter in paperback book form and as a set microfiche.

"Publications of the Geological Survey, 1962-1970" may be purchased by mail and over the counter in paperback book form and as a set of microfiche.

"Publications of the U.S. Geological Survey, 1971-1981" may be purchased by mail and over the counter in paperback book form (two volumes, publications listing and index) and as a set of microfiche.

Supplements for 1982, 1983, 1984, 1985, 1986, and for subsequent years since the last permanent catalog may be purchased by mail and over the counter in paperback book form.

State catalogs, "List of U.S. Geological Survey Geologic and Water-Supply Reports and Maps For (State)," may be purchased by mail and over the counter in paperback booklet form only.

"Price and Availability List of U.S. Geological Survey Publications," issued annually, is available free of charge in paperback booklet form only.

Selected copies of a monthly catalog "New Publications of the U.S. Geological Survey" is available free of charge by mail or may be obtained over the counter in paperback booklet form only. Those wishing a free subscription to the monthly catalog "New Publications of the U.S. Geological Survey" should write to the U.S. Geological Survey, $582 \mathrm{Na}$ tional Center, Reston, VA 22092.

Note.-Prices of Government publications listed in older catalogs, announcements, and publications may be incorrect. Therefore, the prices charged may differ from the prices in catalogs, announcements, and publications. 